\title{
LESZEK ZYGNER
}

Państwowa Uczelnia Zawodowa im. Ignacego Mościckiego w Ciechanowie https://orcid.org/0000-0001-9892-7426

\section{Wybór dokumentów Wydziału do Spraw Wyznań Urzędu Wojewódzkiego w Ciechanowie i Urzędu Wojewódzkiego w Płocku (1975-1989) ze zbiorów Archiwum Akt Nowych w Warszawie}

Działalność Wydziałów do Spraw Wyznań Urzędów Wojewódzkich w Ciechanowie i w Płocku w latach 1975-1989, które formalnie podlegały wojewodom utworzonych w 1975 r. nowych województw, jak również Urzędowi do Spraw Wyznań w Warszawie, była jedną z form realizacji polityki wyznaniowej władz PRL. Poza licznymi dokumentami tych wydziałów, które przechowywane są obecnie w Archiwum Państwowym w Warszawie Oddział w Mławie (zespół: Urząd Wojewódzki w Ciechanowie) oraz w Archiwum Państwowym w Płocku (zespół: Urząd Wojewódzki w Płocku), zachowało się również wiele dokumentów, które przechowywane są w Archiwum Akt Nowych w Warszawie (zespół: Urząd do Spraw Wyznań). W niniejszym wyborze opublikowano 11 spośród tych dokumentów, dotyczących rozmów z duchownymi prowadzonymi na spotkaniach z wojewodami oraz z pracownikami wydziałów, sprawozdania statystyczne na temat kształtowania się stosunków wyznaniowych w poszczególnych województwach, sprawozdania i plany roczne o sytuacji wyznaniowej oraz działalności wydziałów, a także dokumenty powizytacyjne Wydziałów do Spraw Wyznań w Ciechanowie i w Płocku.

Słowa kluczowe: Urząd do Spraw Wyznań, Wydział do Spraw Wyznań w Ciechanowie, Wydział do Spraw Wyznań w Płocku, polityka wyznaniowa, PRL 
W polityce wyznaniowej okresu Polski Ludowej (1944-1989) istotną rolę odgrywał Urząd do Spraw Wyznań w Warszawie, powołany do życia 19 kwietnia 1950 r., a zlikwidowany na mocy ustawy z 23 listopada 1989 r., któremu podlegały odpowiednie struktury terenowe (wydziały wojewódzkie i referaty powiatowe) $)^{1}$. Po wprowadzeniu reformy administracyjnej kraju 1 czerwca 1975 r. również w nowo powstałych urzędach wojewódzkich w Ciechanowie i Płocku zostały powołane wydziały do spraw wyznań ${ }^{2}$, które podlegały Urzędowi do Spraw Wyznań w Warszawie, choć formalnie były komórką Urzędu Wojewódzkiego, a dyrektorzy tychże wydziałów byli mianowani i odpowiedzialni za swoją działalność przed wojewodami. Na mocy rozporządzenia Rady Ministrów z 14 grudnia 1987 r. w sprawie zasad organizacji i funkcjonowania terenowych organów administracji państwowej ${ }^{3}$, a także wytycznych dyrektora generalnego Urzędu do Spraw Wyznań Aleksandra Merkera w sprawie wewnętrznej reorganizacji urzędów wojewódzkich i pozostawienia wydziałów wyznaniowych jedynie w urzędach znajdujących się w stolicach diecezji ${ }^{4}$ wojewoda ciechanowski realizację zadań z zakresu polityki wyznaniowej - na mocy zarządzenia nr 16/88 z 5 września 1988 r. - powierzył pełnomocnikowi do spraw wyznań ${ }^{5}$, którym został dotychczasowy dyrektor miejscowego Wydziału do Spraw Wyznań. Funkcję owego pełnomocnika zlikwidowano na mocy zarządzenia wojewody nr 38/89 z 14 grudnia 1989 r. ${ }^{6}$, a więc już po uchwaleniu przez Sejm uchwały w sprawie likwidacji Urzędu do Spraw Wyznań w Warszawie, natomiast „realizację spraw w zakresie stosunków pomiędzy państwem a Kościołem w PRL oraz innymi Kościołami i związkami wy-

1 Więcej na ten temat: H. Misztal, Polskie prawo wyznaniowe, t. 1: Zagadnienia wstępne. Rys historyczny, Lublin 1996, s. 202-204, 254-259, 261-263; H. Misztal, A. Mezglewski, Zakres kompetencji, styl działania i cele Urzędu do Spraw Wyznań, [w:] A. Mezglewski, P. Stanisz, M. Ordon (red.), Prawo i polityka wyznaniowa w Polsce Ludowej. Materiały II Ogólnopolskiego Sympozjum Prawa Wyznaniowego (Kazimierz Dolny, 26-28 października 2004), Lublin 2005, s. 33-70.

2 Na temat wspomnianych wydziałów i ich działalności zob. A. Grochowski, Polityka wyznaniowa okresu PRL w województwie ciechanowskim, „Ziemia Zawkrzeńska” 2007, nr 11, s. 227-254; A. Szymański, Działalność Wydziału do Spraw Wyznań w Płocku wobec Kościoła katolickiego w latach 1950-1989 w świetle dokumentów Archiwum Państwowego w Płocku, „Studia z Dziejów Państwa i Prawa Polskiego” 2014, nr 17, s. 247-269; L. Zygner, Wydział do spraw Wyznań Urzędu Wojewódzkiego w Ciechanowie 1975-1988/1989, [w:] R. Łatka (red.), Urzq̨d do Spraw Wyznań. Struktury - działalność - ludzie, t. 1: Struktury wojewódzkie i wybrane aspekty działalności, Warszawa 2020, s. 253-287; tenże, Wydział do Spraw Wyznań Urzędu Wojewódzkiego w Płocku (19751989), [w:] Urzq̨d do Spraw Wyznań. Struktury - działalność - ludzie, t. 3 (w druku). Dodam, że w dwóch ostatnich pracach została omówiona obsada kadrowa wydziałów wyznaniowych z Ciechanowa i Płocka, a ustalenia na ten temat znajdują swoje odzwierciedlenie m.in. w aparacie krytycznym przy edycji poszczególnych dokumentów publikowanych w niniejszym wyborze.

3 H. Misztal, A. Mezglewski, dz. cyt., s. 37.

4 Archiwum Akt Nowych w Warszawie (dalej: AAN), Urząd d/s Wyznań, 128/10, Notatka w sprawie wewnętrznej reorganizacji urzędów wojewódzkich i ustanowienia w nich problematyki wyznaniowej, Warszawa 23XII 1987 r., k. 11-12.

5 Archiwum Państwowe w Warszawie, Oddział w Mławie (dalej: APM), Urząd Wojewódzki w Ciechanowie, 2967, Zarządzenie nr 16/88 wojewody ciechanowskiego, Ciechanów 5 IX 1988 r., k. 12.

6 Tamże, 2968, Zarządzenie nr 38/89 wojewody ciechanowskiego w sprawie zmian w statucie Urzędu Wojewódzkiego w Ciechanowie, Ciechanów 14 XII 1989 r., k. 12. 
znaniowymi określonymi w ustawach i przepisach wydanych na ich podstawie" oraz nadzór nad przestrzeganiem zasady wolności sumienia i wyznania, jak również współdziałanie z kościołami i związkami wyznaniowymi w podejmowaniu wspólnych inicjatyw społecznie użytecznych i zwalczaniu patologii społecznych zlecono dyrektorowi Wydziału Organizacyjno-Prawnego Urzędu Wojewódzkiego w Ciechanowie ${ }^{7}$.

Nieco inaczej było w Płocku, który był siedzibą biskupa i stolicą diecezji, dlatego - zgodnie w wytycznymi dyrektora Urzędu do Spraw Wyznań Aleksandra Merkera - w miejscowym Wydziale do Spraw Wyznań nie doszło do powołania pełnomocnika, a sam Wydział dalej działał na dotychczasowych zasadach aż do grudnia 1989 r. Dopiero na mocy zarządzenia nr 53/89 wojewody płockiego z 12 grudnia 1989 r. został zlikwidowany etat dyrektora Wydziału do Spraw Wyznań, natomiast jego kompetencje w zakresie realizacji zadań dotyczących polityki wyznaniowej zostały powierzone dyrektorowi Wydziału OrganizacyjnoPrawnego ${ }^{8}$, co później znalazło swoje odzwierciedlenie w nowym Statucie Urzędu Wojewódzkiego z 28 maja1990 r., gdzie „realizację spraw z zakresu stosunków pomiędzy Państwem a Kościołem Katolickim i innymi Kościołami i związkami wyznaniowymi, określonych w ustawach i przepisach wydanych na ich podstawie” zlecono Wydziałowi Organizacji i Nadzoru tegoż urzędu9 .

W myśl statutów organizacyjnych Urzędu Wojewódzkiego w Ciechanowie i Urzędu Wojewódzkiego w Płocku z 1975 r. utworzone w ich strukturze wydziały wyznaniowe miały zajmować się stosunkami między państwem a Kościołem katolickim oraz innymi związkami wyznaniowymi, co wynikało z założeń ogólnej polityki wyznaniowej państwa. Również szczegółowe zadania obu wydziałów, zarówno w statucie Urzędu Wojewódzkiego w Ciechanowie, jak i w Płocku, zostały opisane podobnie - wynikało to z treści dokumentów wyższego rzędu i obejmowały one:

- sprawy związane z wykonaniem przepisów o organizowaniu i obsadzaniu stanowisk kościelnych,

- nadzór nad zachowywaniem konstytucyjnej zasady ochrony wolności sumienia i wyznania,

- nadzór nad przestrzeganiem prawa państwowego przez kurie diecezjalne, parafie, instytucje i placówki duszpasterskie kościołów i innych związków wyznaniowych oraz przez zakony,

- nadzór nad szkolnictwem kościelnym, w tym nad seminariami, prowadzony razem z kuratorium oświaty i wychowania,

- sprawy związane z budownictwem sakralnym i kościelnym,

Zob. L. Zygner, Wydział do spraw Wyznań Urzędu Wojewódzkiego w Ciechanowie..., dz. cyt., s. 256-257.

8 Archiwum Państwowe w Płocku (dalej: APP), Urząd Wojewódzki w Płocku, 252, Zarządzenie nr 53/89 Wojewody Płockiego, Płock 12 XII 1989 r.

9 APP, Urząd Wojewódzki w Płocku, 262, Statut Urzędu Wojewódzkiego w Płocku, Płock 28 V 1990 r., k. 4. 
- sprawy dotyczące upaństwowienia niektórych nieruchomości kościelnych, a zwłaszcza przejęcia przez państwo dóbr martwej ręki, poręczenia proboszczom posiadania gospodarstw rolnych i utworzenia Funduszu Kościelnego,

- nadzór na cmentarzami wyznaniowymi oraz grzebaniem osób zmarłych,

- nadzór nad działalnością gospodarczą o celach religijnych, prowadzoną przez osoby prawne niebędące jednostkami gospodarki uspołecznionej,

- udzielanie pomocy w rozwijaniu społecznych inicjatyw duchowieństwa,

- koordynacja prac jednostek organizacyjnych Urzędu Wojewódzkiego i jednostek podległych terenowym organom administracji państwowej oraz współdziałanie w sprawach związanych z działalnością kościołów i innych związków wyznaniowych ${ }^{10}$.

Nad realizacją wspomnianych założeń polityki wyznaniowej w ramach administracji terenowej czuwali dyrektorzy i pracownicy Wydziału do Spraw Wyznań w Ciechanowie i Płocku, o czym świadczy dość bogata dokumentacja obu tych wydziałów, która znajduje się obecnie w zbiorach Archiwum Państwowego w Warszawie Oddział w Mławie (w zespole: Urząd Wojewódzki w Ciechanowie) oraz Archiwum Państwowego w Płocku (w zespole: Urząd Wojewódzki w Płocku). Zgodnie z założeniami ogólnej polityki wyznaniowej państwa, a także regulaminem dotyczącym działalności Urzędu do Spraw Wyznań w Warszawie, któremu podlegały oba omawiane tu wydziały, wiele dokumentów dotyczących bieżącej działalności tych wydziałów było przesyłanych do centrali w Warszawie. Obecnie przechowywane są one w zbiorach Archiwum Akt Nowych w Warszawie (w zespole: Urząd do Spraw Wyznań) i właśnie 11 spośród nich zostanie tu opublikowanych. Przy wyborze tych dokumentów starano się uwzględnić kilka ich rodzajów, aby lepiej zobrazować codzienną działalność terenowej administracji wyznaniowej. Są tu więc dokumenty dotyczące rozmów z duchownymi prowadzonymi na spotkaniach z wojewodami oraz z pracownikami wydziałów, sprawozdania statystyczne na temat kształtowania się stosunków wyznaniowych w poszczególnych województwach, sprawozdania i plany roczne na temat sytuacji wyznaniowej oraz działalności wydziałów, dokumenty powizytacyjne $\mathrm{Wy}$ działów do Spraw Wyznań w Ciechanowie i w Płocku.

Przy edycji prezentowanych materiałów uwzględniono zasady wydawnicze stosowane przy publikacjach źródłowych Instytutu Pamięci Narodowej. Wszelkie ingerencje redakcyjne zostały ujęte w nawiasy kwadratowe, a inne opatrzono przypisanymi oznaczonymi literami. Błędy w tekstach oryginalnych zaznaczono znakiem [!]. Informacje o pieczęciach, podpisach i adnotacjach zostały umieszczone w przypisach tekstowych. Wszelkie wyróżnienia w oryginalnym tekście (najczęściej podkreślenia) oddano czcionką pogrubioną. Każdy dokument został poprzedzony krótkim regestem z podaniem daty i miejsca jego wydania. Natomiast wszelkie ko-

10 APM, Urząd Wojewódzki w Ciechanowie, 2949, Statut organizacyjny Urzędu Wojewódzkiego w Ciechanowie, Ciechanów 27 V 1975 r., k. 58-59; APP, Urząd Wojewódzki w Płocku, 9, Statut organizacyjny Urzędu Wojewódzkiego w Płocku, Płock lipiec 1975 r., k. 23-24. 
mentarze i wyjaśnienia merytoryczne oraz informacje o osobach pojawiających się w dokumentach zamieszczono w przypisach rzeczowych oznaczonych liczbami. Na końcu umieszczono - zapisując kursywą - informacje o miejscu przechowywania danego dokumentu, jego sygnaturze oraz podano numery oryginalnych kart.

\title{
Edycja źródłowa
}

\section{Nr 1}

1975 październik, Ciechanów - Plan przygotowany przez Wydział ds. Wyznań Urzędu Wojewódzkiego w Ciechanowie dotyczqcy spotkań i rozmów z duchowieństwem rzymsko-katolickim na terenie województwa ciechanowskiego w październiku i listopadzie $1975 \mathrm{r}$.

\section{Projekt}

\section{Poufne}

\author{
Plan \\ spotkań i rozmów z duchowieństwem kościoła \\ Rzymskokatolickiego w woj[ewództwie] ciechanowskim \\ w m[iesią]cach październik-listopad 1975 r.
}

\section{Założenia ogólne:}

W całokształcie metod oddziaływania, których głównym celem jest lojalizacja kleru, ważną rolę odgrywają spotkania i rozmowy władz z duchowieństwem. Przeprowadzona w ubiegłym roku na temat dorobku 30-lecia PRL oraz w roku bieżącym związana z przyznawaniem odznaczeń państwowych z okazji 30-lecia zwycięstwa nad faszyzmem wymagają kontynuowania. Sprzyjają temu aktualnie nowe, ważkie obywatelskie tematy: podsumowanie dokonań ostatniego pięciolecia oraz reforma administracji terenowej.

Wychodząc z założenia celowości i potrzeby kontynuowania tej formy pracy z duchowieństwem, zgodnie z zaleceniami i wytycznymi władz centralnych ustala się plan spotkań i rozmów z księżmi, zwłaszcza dziekanami i proboszczami z terenu woj[ewództwa] ciechanowskiego w okresie październik-listopad 1975 r.

\section{Cel i tematyka spotkań i rozmów:}

Podstawowym celem spotkań zbiorowych i rozmów indywidualnych jest zbliżenie księży - dziekanów i administratorów parafii - do nowych władz terenowych i zapoznanie z problematyką ich funkcjonowania poprzez m.in.:

1. zaprezentowanie duchowieństwu dorobku ostatniego pięciolecia oraz zapoznanie z perspektywą dalszego rozwoju kraju, a w szczególności województwa;

2. omówienie niektórych zagadnień związanych z polityką wyznaniową Państwa, zwłaszcza stosunkami Państwo-Kościół; 
3. omówienie wybranych zagadnień lokalnych odnoszących się do pracy i zainteresowań księży, a mających istotny wpływ na lojalizację duchowieństwa, przestrzeganie porządku prawnego i usuwanie konfliktów;

\section{Grupa aktywu do przeprowadzenia rozmów:}

1. Do przeprowadzenia rozmów powołuje się grupę aktywu spośród kadrowych pracowników Urzędu Wojewódzkiego w składzie:

1. Władysław Milanowski - dyr[ektor] Wydziału d/s Wyznań ${ }^{1}$

2. Jan Gorzki - Kurator Oświaty i Wychowania ${ }^{2}$

3. Włodzimierz Gołębiewski - z[astęp]ca dyr[ektora] Wydz[iału] Spraw Wewnętrznych $^{3}$

4. Zbigniew Leczycki - dyr[ektor] Wydz[iału] Gosp[odarki] Teren[owej] i Ochr[ony] Środowiska ${ }^{4}$

5. Daniel Ciok - dyr[ektor] Wydz[iału Kultury i Sztuki ${ }^{5}$

6. Stefan Odachowski - Starszy Insp[ektor] Woj[ewódzki] Wydz[iału] d/s Wyznań ${ }^{6}$

7. Jan Jankowski - Insp[ektor] Woj[ewódzki] Wydz[iału] d/s Wyznań ${ }^{7}$

2. Za merytoryczne przygotowanie wymienionych towarzyszy do przeprowadzenia rozmów odpowiedzialny - Wł[adysław] Milanowski - dyr[ektor] Wydziału d/s Wyznań. Termin: październik 1975 r.

3. Materiały pomocnicze do rozmów stanowić będą: „Tezy do rozmów z duchowieństwem /jesień 1975/" opracowane przez Wydz[iał] Adm[inistracyjny] KC [PZPR]. Ponadto należy wykorzystać: Wytyczne KC PZPR na VII Zjazd Partii; wystąpienia I Sekretarza KC tow. Edwarda Gierka, a w szczególności: na spotkaniu w Sosnowcu, z naukowcami w Warszawie, przedstawicielami gospodarki morskiej w Gdańsku oraz materiały na Wojewódzką Konferencję Przedzjazdową w Ciechanowie.

\section{Założenia organizacyjne i terminarz rozmów:}

\section{A. Spotkania zbiorowe:}

1. Zorganizować spotkania zbiorowe Wojewody Ciechanowskiego tow. mgr Jerzego Wierzchowskiego z dziekanami i reprezentacją proboszczów z większych parafii i środowisk z terenu województwa, z następującym programem:

1 Władysław Milanowski - dyrektor Wydziału do Spraw Wyznań Urzędu Wojewódzkiego w Ciechanowie w latach 1975-1988.

Jan Gorzki - ciechanowski kurator oświaty i wychowania w latach 1975-1982.

3 Włodzimierz Gołębiewski - zastępca dyrektora Wydziału Spraw Wewnętrznych Urzędy Wojewódzkiego w Ciechanowie od $1975 \mathrm{r}$.

4 Zbigniew Leczycki - dyrektor Wydziału Gospodarki Terenowej i Ochrony Środowiska Urzędu Wojewódzkiego w Ciechanowie od 1975 r.

5 Daniel Ciok - dyrektor Wydziału Kultury i Sztuki Urzędu Wojewódzkiego w Ciechanowie w latach 1975-1982.

6 Stefan Odachowski - pracownik Wydziału ds. Wyznań Urzędu Wojewódzkiego w Ciechanowie w latach 1975-1982.

7 Jan Jankowski - pracownik Wydziału ds. Wyznań Urzędu Wojewódzkiego w Ciechanowie w latach 1975-1983. 
- Wystąpienie tow. Wojewody na temat: Osiągnięcia społeczno-gospodarcze ostatniego pięciolecia oraz reforma administracji terenowej i jej znaczenie dla dalszego dynamicznego rozwoju kraju i województwa,

- dyskusja: wymiana zdań i poglądów na aktualne tematy interesujące obie strony.

Przewiduje się, że w spotkaniu weźmie udział grupa 20-27 księży. Lista duchownych proponowanych na spotkanie - Zał. nr $1^{8}$.

Z Urzędu Wojewódzkiego w spotkaniu powinni wziąć udział dyrektorzy Wydz[iałów]: d/s Wyznań, Kurator Oświaty i Wychowania, Spraw Wewnętrznych, Finansowego, Gospodarki Terenowej i Ochrony Środowiska.

Miejsce spotkania: Sala Konferencyjna Urzędu Wojewódzkiego w Ciechanowie.

Termin spotkania: ${ }^{a}$

Szczegółowy scenariusz spotkania opracuje dyrektor Wydziału d/s Wyznań.

2. Zorganizować spotkanie księży, członków Zrzeszenia Katolików „Caritas” z terenu województwa. Zasadniczy temat spotkania jak w pkt. 1. /wystąpienie tow. Wojewody lub wyznaczonego Wicewojewody/ i sprawy organizacyjne - powołanie oddziału wojew[ódzkiego], przygotowanie programu działania i rozwoju organizacyjnego Zrzeszenia. Udział w nim wezmą księża członkowie i sympatycy Zrzeszenia „Caritas” z terenu województwa, przedstawiciele Oddziału Rejonowego „Caritas” z Warszawy.

Miejsce spotkania: Sala Konferencyjna Urzędu Wojewódzkiego w Ciechanowie. Termin: koniec listopada lub pierwsza połowa grudnia br. /po otrzymaniu zaleceń i wytycznych z Urzędu d/s Wyznań/.

Lista imienna uczestników i szczegółowy program spotkania zostaną przygotowane w terminie późniejszym.

Odpowiedzialny dyr[ektor] Wydziału d/s Wyznań.

3. Odbyć grupowe spotkania z księżmi /2-4 osoby/ w następujących gminach:

- Baboszewo - 2 księży

- Dzierzążnia - 2 księży

8 W załączniku (AAN, Urząd d/s Wyznań, sygn. 125/66, k. 265-268) wymieniono następujących duchownych zaproszonych na spotkanie z wojewodą ciechanowskim: ks. Stanisław Tenderenda (Ciechanów), ks. Sylwester Kończal (Działdowo), ks. Stefan Budczyński (Mława), ks. Marian Czapla (Mława-Wólka), ks. Stanisław Kowalczyk (Płońsk), ks. Józef Mikołajewski (Pułtusk), ks. Anastazy Rutkowski (Pułtusk), ks. Jan Danielewicz (Lidzbark Welski), ks. Edward Czajkowski (Nasielsk), ks. Alojzy Poszwa (Raciąż), ks. Kazimierz Żbikowski (Żuromin), ks. Stefan Zalewski (Bieżuń), ks. Tadeusz Fijałkowski (Rostkowo), ks. Kazimierz Pawłowski (Węgra), ks. Jan Dominik (Narzym), ks. Wiesław Wiśniewski (Sulerzyż), ks. Stanisław Pilitowski (Gołymin), ks. Henryk Kosiński (Grudusk), ks. Jan Radomski (Cieksyn), ks. Eugeniusz Pydyński (Zielona Ciechanowska), ks. Tadeusz Trzciński (Kuczbork), ks. Józef Molęda (Zielona Mławska), ks. Stefan Płoski (Lutocin), ks. Jan Połomski (Niedzbórz), ks. Józef Kardynał (Nowe Miasto), ks. Jan Jeż (Pałuki), ks. Kazimierz Goldstrom (Wielki Łęck), ks. Czesław Kiliś (Dzierżenin), ks. Mieczysław Hościłowicz (Rybno) ks. Stanisław Załęski (Gradzanowo), ks. Stanisław Zakrzewski (Sochocin), ks. Józef Jankiewicz (Strzegowo), ks. Henryk Piórkowski (Klukowo) i ks. Antoni Wincenty Gawarecki (Kroczewo).

a Brak wpisu. 
- Gzy - 3 księży

- Naruszewo - 4 księży

- Raciąż - 3 księży

- Regimin - 3 księży

- Sońsk - 4 księży

- Strzegowo - 2 księży

- Stupsk - 2 księży

- Wieczfnia - 2 księży

Gospodarzami spotkań będą naczelnicy gmin, z którymi należy odbyć naradę celem merytorycznego przygotowania ich do spotkań i krótkich wystąpień na temat dorobku i perspektyw rozwojowych gminy. Naradę z naczelnikami odbyć w terminie do 10 listopada br. Odpowiedzialny dyr[ektor] Wydziału d/s Wyznań.

Spotkania w gminach odbyć w okresie 15-30 listopada br. Lista księży objętych tymi rozmowami - zał. nr $2^{9}$. Szczegółowy terminarz spotkań zostanie ustalony z naczelnikami gmin.

W spotkaniach wezmą udział towarzysze z ustalonej grupy aktywu, a w szczególności pracownicy Wydziału d/s Wyznań.

\section{B. Rozmowy indywidualne:}

Planuje się przeprowadzenie rozmów indywidualnych:

1. Z grupą księży katechetów i kandydatów na katechetów około 30-35 księży /lista otwarta/. Termin 14-30 październik br. Rozmowy będą prowadzone w Wydziale d/s Wyznań w[edłu]g szczegółowego oddzielnie opracowanego harmonogramu. Odpowiedzialny dyr[ektor] i inspektorzy Wydz[iału] d/s Wyznań.

2 Z grupą około 25-30 księży, którym umarzane ${ }^{b}$ będą zaległości podatkowe / podstawa: Zarządzenie Ministra Finansów z dnia 8 sierpnia 1975 r. w sprawie całkowitego lub częściowego zwalniania od podatków od nieruchomości i lokali kościelnych osób prawnych oraz wytyczne w tej sprawie Ministra-Kierownika Urzędu d/s Wyznań/. Lista księży i szczegółowy terminarz rozmów zostaną opracowane w terminie późniejszym.

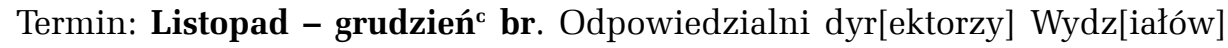
d/s Wyznań i Finansowego.

3. Z księżmi podejmującymi budownictwo /remonty/ sakralne i kościelne /przewidywana grupa 15-20 księży/.

9 Załącznik z wykazem imiennym zaproszonych księży nie zachował się, ale w oparciu o przesłaną z Wydziału ds. Wyznań Urzędu Wojewódzkiego w Ciechanowie do Urzędu ds. Wyznań w Warszawie ankietę (AAN, Urząd d/s Wyznań, sygn. 125/68, k. 41) udało się ustalić miejsca i terminy spotkań duchownych na terenie 11 gmin województwa ciechanowskiego: Lidzbark Welski (19 XI 1975), Gzy (19 XI 1975), Stupsk (20 XI 1975), Baboszewo (21 XI 1975), Dzierzążnia (21 XI 1975), Naruszewo (25 XI 1975), Wieczfnia (25 XI 1975), Strzegowo (25 XI 1975), Sońsk (26 XI 1975), Raciąż (28 XI 1975) i Regimin (2 XII 1975).

b Wpisano: umażane.

c Zapisano: październik i poprawiono ręcznie: grudzień. 
Termin: listopad-grudzień. Szczegółowy harmonogram zostanie opracowany w terminie późniejszym, po nadesłaniu przez Kurię planu potrzeb w tym zakresie na rok 1976.

Za realizację niniejszego planu i bieżącą informację oraz sprawozdawczość odpowiedzialny dyrektor Wydziały d/s Wyznań

Październik 1975 r.

Urząd Wojewódzki Wydział do Spraw Wyznań w Ciechanowie

Źródło: AAN, Urzq̨d d/s Wyznań w Warszawie, sygn. 125/66, k. 260-263, oryginał, mps.

\title{
Nr 2
}

1975 listopad 15, Ciechanów - Informacja ze spotkania duchownych z wojewodq ciechanowskim oraz rozmów indywidualnych pracowników Wydziału d/s Wyznań Urzędu Wojewódzkiego w Ciechanowie z administratorami parafii z terenu województwa ciechanowskiego, odbytych $w$ dniach 15 października-12 listopada $1975 \mathrm{r}$.

aPoufne

Egz. $\mathrm{nr} 1$

Ciechanów, dnia 15 listopada 1975 r.

\begin{abstract}
Informacja
ze spotkania zbiorowego i rozmów indywidualnych

$\mathrm{z}$ administratorami parafii z terenu województwa ciechanowskiego, odbytych w terminie od 15 października do 12 listopada $1975 \mathrm{r}$.
\end{abstract}

\section{Przygotowania organizacyjne}

Wydział do Spraw Wyznań Urzędu Wojewódzkiego w Ciechanowie opracował na początku października br. plan spotkań zbiorowych i rozmów indywidualnych z duchowieństwem kościoła Rzymskokatolickiego na okres październik-grudzień 1975 r. /Plan w załączniku/. Plan w/w został omówiony i zatwierdzony na tzw. małym zespole w dniu 9.10.1975 r., a następnie na Zespole Wojewódzkim dnia 23.10. br. Jego realizacja przedstawia się następująco: a lewym górnym rogu pieczqtka podłużna: Urząd Wojewódzki w Ciechanowie Wydział d/s Wy-
znań i liczba dziennika: Wz.051/7/75. 


\section{A. Spotkanie zbiorowe:}

1. Zorganizowano dnia 12.11 .1975 r. spotkanie zbiorowe Wojewody Ciechanowskiego tow. mgr Jerzego Wierzchowskiego ${ }^{1} \mathrm{z}$ dziekanami i reprezentacją proboszczów większych parafii z terenu województwa z następującym programem:

a/ wystąpienie tow. Wojewody na temat: aktualne problemy społeczno-gospodarcze oraz perspektywy dalszego rozwoju województwa ciechanowskiego w nowym układzie administracyjnym kraju,

b/ dyskusja: wymiana zdań i poglądów na aktualne tematy interesujące obie strony.

2. Zaplanowano udział w spotkaniu grupy 25-30 księży - dziekanów, v-ce dziekanów i proboszczów większych parafii. Listę zaproszonych wstępnie ustalono na Zespole w dniu 9.10. br., a następnie po gruntownym rozeznaniu aktualizowano i uzupełniono zwiększając liczbę księży do 34 osób.

3. Przygotowano tekst zaproszeń, które osobiście wręczyli księżom Naczelnicy miast i gmin na spotkaniach w urzędach miejskich i gminnych w dniu 8.11.1975 r. W przeddzień /7.11. br./ na odbywającej się naradzie w U[rzędzie] W[ojewódzkim] naczelnicy zostali poinformowani i przygotowani do spotkań z księżmi i wręczenia im zaproszeń. Następnie naczelnicy złożyli meldunki telefoniczne z przebiegu spotkań i wręczenia zaproszeń w dniu 10.11.1975 r.

4. Dyrektor Wydziału d/s Wyznań ${ }^{2} \mathrm{w}$ terminie do 7.11.[19]75 r. przygotował materiały pomocnicze dla Wojewody oraz program spotkania ze szczegółowym scenariuszem na dzień 12.11. br.

\section{Przebieg spotkania zbiorowego}

Spotkanie odbyło się zgodnie z planem 12.11.1975 r. w godzinach od 10.00 12.30. Miało ono przebieg następujący:

- godz. 10.00 na salę konferencyjną wszedł Wojewoda Ciechanowski w towarzystwie Dyrektora Wydziału d/s Wyznań. Przywitał zebranych przedstawicieli duchowieństwa ogólnie i następnie osobiście z każdym indywidualnie.

- godz. 10.05 Tow. Wojewoda zagaił spotkanie i krótko określił cel i tematykę,

- godz. 10.10 wystąpienie Wojewody na temat: aktualne problemy społeczno-gospodarcze oraz perspektywy dalszego rozwoju województwa ciechanowskiego w nowym układzie administracyjnym kraju. Wojewoda między innymi omówił:

1. Charakterystykę ogólną województwa w nowym układzie administracyjnym kraju. Racje społeczne, ekonomiczne i przesłanki historyczne jego utworzenia.

Jerzy Adam Wierzchowski - wojewoda ciechanowski w latach 1975-1987.

Chodzi o Władysława Milanowskiego - dyrektora Wydziału ds. Wyznań Urzędu Wojewódzkiego w Ciechanowie w latach 1975-1988. 
2. Potrzebę integracji społeczeństwa całego województwa wokół realizacji zadań społeczno-gospodarczych.

3. Osiągnięcia społeczno-gospodarcze w ostatnim pięcioleciu w województwie, kraju i miejsce Polski w świecie.

4. Plan społeczno-gospodarczy i perspektywy rozwoju województwa w latach 1976-1980.

5. Potrzebę współdziałania duchowieństwa z władzami w zakresie przestrzegania prawa i umocnienia naszej Ojczyzny.

Uczestnicy spotkania wystąpienie Wojewody przyjęli z wielką uwagą i zainteresowaniem. Znalazło to potwierdzenie w dyskusji. Większość dyskutantów dziękowała w serdecznych słowach za zaproszenie i możliwość uczestniczenia w spotkaniu.

Głos w dyskusji zabrało 10 księży

Ks. Jan Dominik ${ }^{3}$ - administrator parafii Narzym /czł[onek] „Caritasu”/. Podziękował w imieniu księży za zaproszenie i wyczerpującą informację o województwie ciechanowskim. Następnie omówił monografię miejscowości i kościoła w Narzymiu. Prosił o pomoc finansową i fachowy nadzór nad remontem zabytkowego kościoła. Poparł wystąpienie Wojewody w kwestii wspólnego działania w zakresie zwalczania ujemnych zjawisk w społeczeństwie, jak pijaństwo i chuligaństwo.

Ks. Prałat mgr Stanisław Tenderenda ${ }^{4}$ - dziekan z Ciechanowa. Wyraził radość i podziękowanie za spotkanie z władzami administracyjnymi województwa ciechanowskiego. Między innymi powiedział: „Ideologicznie się różnimy, ale cel mamy jednakowy. Obok różnic łączy nas cel - dobro Polski”. Z radością stwierdzamy poprawę dobrobytu społeczeństwa - to nas łączy. Najważniejszą rzeczą jest - humanizm - człowiek pracowity, prawy i sumienny. Takich ludzi staramy się wychować i w tej kwestii będziemy wspólnie pracować dla dobra kraju i narodu. Przytoczył cytat z trylogii ${ }^{5} \mathrm{H}$ [enryka] Sienkiewicza: „Nie ma takich terminów, żebyśmy nie mogli przezwyciężyć wszelkich trudności i osiągnąć naszych zamierzonych celów”b. Wspólna nasza praca winna wydać owoce. Na zakończenie prosił Wojewodę o zwrócenie lub odkupienie domu parafialnego w Ciechanowie zajmowanego przez szkołę i inne instytucje państwowe.

Ks. Jan Jeż $\dot{z}^{6}$ - administrator parafii Pałuki /czł[onek] „Caritasu”/. Ucieszyłem się, że Wojewoda wyciąga dłoń do współpracy z nami. Etyka każda, również

$3 \quad$ Ks. Jan Dominik - kapłan diecezji chełmińskiej, wikariusz (1963/1964) i proboszcz parafii w Narzymiu (1972-1982).

4 Ks. Stanisław Tenderenda - kapłan diecezji płockiej, proboszcz i dziekan w Ciechanowie w latach 1958-1976.

5 Chodzi o słynny toast Zagłoby z „Potopu” Henryka Sienkiewicza: Niech gdy ciężkie czasy nadejdq, wspomnq na nas i nie desperuja nigdy, baczq̨c na to, że nie masz takowych terminów, z których by się viribus unitis przy boskich auxiliach podnieść nie można.

b Na marginesie dopisane odręcznie: „których byśmy przy boskiej pomocy itd.” i pod spodem nieczytelny podpis.

${ }_{6} \quad$ Ks. Jan Jeż - kapłan diecezji płockiej, proboszcz w Pałukach w latach 1971-1980. 
i chrześcijańska nakazuje dobro. Pracujemy i nauczamy, aby człowieka wychować społecznie. Nawołujemy, popieramy i włączamy się do czynów społecznych dla wspólnego dobra. Wierzę, że nasze kontakty staną się jeszcze lepsze, częstsze i bardziej rzeczowe. Należy życzyć, aby stosunki między nami rozwijały się poprawnie dla wspólnego dobra narodu i kraju.

Ks. Marian Czapla ${ }^{7}$ - administrator parafii Mława-Wólka. Poinformował o postępach w budowie nowego kościoła i związanych z tym trudnościach materiałowych. Wspomniał o nagromadzonych materiałach na budowę kościoła przed 1939 r., które rozgrabił okupant hitlerowski w czasie wojny na budownictwo mieszkaniowe w Mławie. Prosił Wojewodę o pomoc finansową oraz przydział materiałów na budowę kościoła. A nawet jego zdaniem - władze powinny zrekompensować zabrane przez okupanta materiały /nagromadzone na kościół/ ponieważ wybudowano z nich 9 bloków mieszkalnych w Mławie, które służą do dziś miastu i społeczeństwu.

Ks. Infułat Anastazy Rutkowski ${ }^{8}$ - prepozyt Kapituły Pułtuskiej mówił o zabytkach architektonicznych w Pułtusku, a szczególnie sakralnych. Nadmienił, że Pułtusk - 14 tysięczne miasto ma do odnotowania dwa ważne wydarzenia:

- w 1974 r. - władze centralne podjęły decyzję o odbudowie zamku biskupów pułtuskich ${ }^{9}$ i przekazania go na ośrodek dla Polonii.

- 1975 r. - podniesienie dekretem papieskim Kolegiaty Pułtuskiej do godności Bazyliki Mniejszej, która stała się kościołem papieskim. Trzeba by wiedziano o tym nie tylko w województwie, ale w całym kraju i na całym świecie.

Prosił Wojewodę i Dyrektora Wydziału do Spraw Wyznań o szczególną opiekę, pomoc i zrozumienie w odbudowie pułtuskich zabytków sakralnych. Swoje wystąpienie zakończył słowami: „Chwała i sława województwa będzie naszą chwałą i sławą. Chwała i sława województwa będzie z naszej chwały i sławy".

Ks. Kanonik Józef Mikołajewski ${ }^{10}$ - administrator parafii Pułtusk i vicedziekan dek[anatu] Pułtusk. Podziękował w serdecznych słowach za zaproszenie i wyraził nadzieję, aby współpraca z władzami państwowymi układała się jak najlepiej. Prosił o pozytywne załatwienie wniosku, trzykrotnie zgłaszanego przez Kurię Płocką w sprawie erygowania parafii Św[iętego] Krzyża w Pułtusku. Dla uzdrowienia atmosfery jak wytworzyła się wokół tej sprawy istnieje potrzeba zalegalizowania tej parafii, która jest de facto, a nie zatwierdzona przez władzę państwową. Wspomniał również, że Kuria Płocka wysłała list do Prezesa Rady

Ks. Marian Czapla - kapłan diecezji płockiej, proboszcz parafii Mława-Wólka w latach 1962-1987, wicedziekan mławski w latach 1972-1987.

$8 \quad$ Ks. Anastazy Rutkowski - kapłan diecezji płockiej, proboszcz i dziekan pułtuski w latach 19591975.

9 Chodzi o zamek biskupów płockich, którzy rezydowali w Pułtusku, a tylko przez krótki czas w XVIII w. rezydowali w nim biskupi pomocniczy pułtuscy.

10 Ks. Józef Mikołajewski - kapłan diecezji płockiej, proboszcz pułtuski w latach 1975-1992, wicedziekan (1975-1978) i dziekan pułtuski (1978-1987). 
Ministrów o pozytywne załatwienie tej sprawy, ponieważ jest ona niezmiernie ważna dla nas wszystkich. Przyjeżdżają i widzą bowiem ruiny Polacy z zagranicy, a to nie przynosi nam chwały i dobrego imienia. Swoje wystąpienie zakończył słowami: „Z góry będziemy się cieszyć z każdego osiągnięcia, będziemy współpracować dla wspólnego dobra społeczeństwa i naszej Ojczyzny".

Ks. Kanonik mgr Stanisław Kowalczyk ${ }^{11}$ - administrator parafii Płońsk i dziekan dekanatu płońskiego. Postulował dalszy rozwój miasta Płońska, a szczególnie budownictwa mieszkaniowego, ponieważ wielu ludzi mieszka jeszcze w bardzo trudnych warunkach. Nadmienił, że Płońsk leży nisko w naturalnej kotlinie, a wilgoć powoduje choroby reumatyczne. Postulował osuszenie terenu miasta i poprawienie warunków zdrowotnych jego mieszkańców. Swoje wystąpienie zakończył słowami: „Uważam, że doczekamy się również pozytywnej decyzji w sprawie budowy nowej plebanii w Płońsku, bo warunki w jakich żyjemy i pracujemy są jedne z gorszych w diecezji i województwie”.

Ks. Prałat dr Alojzy Poszwa ${ }^{12}$ - administrator parafii Raciąż i dziekan dekanatu raciążskiego. Podziękował za zaproszenie. Mówił o problemie wychowania człowieka jako sprawie najważniejszej. Podkreślił, że Ojczyzna jest nam wszystkim nadzwyczaj droga, a władza państwowa - polska jest naszą władzą. Apelował do Wojewody o uwagę i troskę w rozwoju mniejszych osiedli takich jak Raciąż, który od wielu lat nie uzyskał żadnych ważniejszych inwestycji. Stwierdził na zakończenie, że zawsze stał na stanowisku utrzymywania dobrych stosunków z władzami i takie stosunki w praktyce utrzymywał, ponieważ musi nas łączyć wspólny nadrzędny cel - interes i dobro Polski, interes i dobro naszego narodu, naszej Ojczyzny.

Ks. Edward Czajkowski ${ }^{13}$ - administrator parafii Nasielsk i dziekan dekanatu nasielskiego. Poruszył następujące sprawy:

- trudności w zaopatrzeniu w wodę mieszkańców Nasielska,

- zanieczyszczenie rzeki, która zatruwa powietrze,

- potrzebę budowy dworca PKP i więcej mieszkań,

- prośbę o zwiększenie metrażu zatwierdzonej przez Wydział budowy nowej plebanii.

Ks. Stanisław Załęski ${ }^{14}$ - administrator parafii Gradzanowo /czł[onek] „Caritasu”/. Rozpoczął swoje wystąpienie od wspomnień z ż życia ludzi pracy w okresie międzywojennym w Ciechanowie, gdzie był wikariuszem. Podkreślił, że trudne warunki życia społeczeństwa przed wojną oraz nieszczęścia lat wojny i okupa-

${ }^{11}$ Ks. Stanisława Kowalczyk - kapłan diecezji płockiej, proboszcz i dziekan płoński w latach 19671981.

12 Ks. Alojzy Poszwa - kapłan diecezji płockiej, proboszcz i dziekan raciąski w latach 1948-1979.

13 Ks. Edward Czajkowski - kapłan diecezji płockiej, proboszcz w Nasielsku (1973-1986), wicedziekan (1974-1975) i dziekan nasielski (1975-1986).

14 Ks. Stanisław Załęski - kapłan diecezji płockiej, proboszcz w Gradzanowie w latach 1956-1976, wicedziekan raciąski (1957-1972).

c Litera dopisana ręcznie. 
cji były dziełem władz sanacyjnej Polski. Wyraził się z uznaniem o dzisiejszych władzach, które doprowadziły do dynamicznego rozwoju kraju i województwa. Swoje wystąpienie zakończył słowami: „Dzisiejsze zgromadzenie łączy nas do współpracy. My duchowni tę współpracę pod godłem orła białego deklarujemy. Ziemia ta jest naszą ziemią, dokładamy również swoją cegiełkę do wspólnego dzieła, chcemy współpracować i prosimy o współpracę".

Dyskusję podsumował Wojewoda Ciechanowski. Ustosunkował się do niektórych wypowiedzi księży, a w szczególności:

- budowy kościoła w Mławie-Wólce,

- budowy plebanii w Opinogórze,

- konieczności bilansowania wydawanych zezwoleń na budownictwo z zaopatrzeniem materiałowym i siły przerobu przedsiębiorstw budowlanych,

- budowy ujęć wody i oczyszczalni ścieków w Nasielsku,

- poinformował o pracy zespołu wojewódzkiego w zakresie uporządkowania kompleksu zabytków w Pułtusku i Opinogórze.

Tow. Wojewoda zapewnił uczestników spotkania, że zgłoszone postulaty zostaną wnikliwie zbadane i każdy z dyskutantów otrzyma odpowiedź pisemną. Wyraził nadzieję, że spotkanie nasze będzie służyło dobru wspólnemu. Podkreślił, że w dążeniach do zapewnienia narodowi lepszych warunków życia nic nas nie dzieli a wszystko łączy. Na zakończenie tow. Wojewoda podziękował księżom za przybycie i aktywny udział w spotkaniu, wyrażając przekonanie, iż było ono potrzebne dla wzajemnego poznania się oraz korzystne dla obu stron, wspomniał jednocześnie - co potwierdzili w swych wystąpieniach księża - o potrzebie takich spotkań w przyszłości.

Następnie osobiście pożegnał się indywidualnie z uczestnikami spotkania.

\section{Ważniejsze wnioski i postulaty zgłoszone w dyskusji przez księży na spotka- niu z Wojewodą}

1. Ks. Stanisława Tenderenda z Ciechanowa prosi o zwrot domu parafialnego zajmowanego przez szkołę i inne instytucje państwowe.

2. Ks. Marian Czapla z Mławy domaga się rekompensaty za materiały zgromadzone na kościól, a zagrabione przez okupanta hitlerowskiego i zużyte na wybudowanie 9 bloków mieszkalnych w Mławie. Postuluje również poprawę zaopatrzenia $\mathrm{w}$ materiały budowlane na potrzeby budownictwa sakralnego i kościelnego.

3. Ks. Jan Dominik z Narzymia prosi o dotację z funduszu na konserwację i remont zabytkowego kościoła w Narzymiu.

4. Ks. Józef Mikołajewski z Pułtuska prosi o erygowanie parafii Św[iętego] Krzyża i remont dachu kościoła.

5. Ks. Stanisław Kowalczyk z Płońska prosi o wyrażenie zgody na budowę nowej plebanii.

6. Ks. Edward Czajkowski z Nasielska prosi o większy metraż plebanii, na budowę której otrzymał zezwolenie. 
Wybór dokumentów Wydziału do Spraw Wyznań Urzędu Wojewódzkiego w Ciechanowie...

III. Frekwencja na spotkaniu

\begin{tabular}{|l|c|c|c|c|c|}
\hline \multicolumn{1}{|c|}{ Treść } & Ogółem & $\begin{array}{c}\text { W tym: } \\
\text { dziekanów }\end{array}$ & $\begin{array}{c}\text { wicedzie- } \\
\text { kanów }\end{array}$ & $\begin{array}{c}\text { probosz- } \\
\text { czów }\end{array}$ & $\begin{array}{c}\text { Z liczby } \\
\text { ogółem człon- } \\
\text { ków „Caritas” }\end{array}$ \\
\hline Zaproszono & 34 & 8 & 4 & 22 & 6 \\
\hline Obecnych & 23 & 6 & 2 & 15 & 4 \\
\hline Nieobecnych & 11 & 2 & 2 & 7 & 2 \\
\hline
\end{tabular}

Usprawiedliwili swoją nieobecność:

1. Ks. Kanonik Jan Danielewicz ${ }^{15}$ - dziekan dek[anatu] Lidzbark - został wezwany na konferencję do Kurii w Pelplinie.

2. Ks. Sylwester Kończal ${ }^{16}$ - wicedziekan dek[anatu] Lidzbark - został wezwany na konferencję do Kurii w Pelplinie.

3. Ks. Kanonik Kazimierz Żbikowski z Żuromina ${ }^{17}$ - wyjechał do USA.

4. Ks. Kazimierz Pawłowski z Węgry ${ }^{18}$ - wyjechał za granicę.

5. Ks. Kanonik mgr Jan Radomski z Cieksyna ${ }^{19}$ - chory na grypę.

6. Ks. Stefan Płoski z Lutocina ${ }^{20}$ - wyjechał na rekolekcje do Krakowa.

7. Ks. Mieczysław Hościłowicz z Rybna ${ }^{21}$ - wezwany na konferencję do Kurii w Pelplinie.

Nie usprawiedliwili nieobecności:

1. Ks. Stefan Zaleski ${ }^{\mathrm{z}}$ z parafii Bieżuń ${ }^{22}$.

2. Ks. Wiesław Wiśniewski z parafii Sulerzyż/vice dziekan/23.

3. Ks. Kanonik Tadeusz Trzciński z Kuczborka/dziekan/24.

4. Ks. Józef Molęda z parafii Zielona - czł[onek] Zrzeszenia „Caritas”25.

$15 \quad$ Ks. Jan Danielewicz - kapłan diecezji chełmińskiej, proboszcz w Lidzbarku Welskim w latach 1971-1977, dziekan lidzbarski w latach 1966-1977.

16 Ks. Sylwester Kończal - kapłan diecezji chełmińskiej, wikariusz (1967), następnie proboszcz parafii św. Wojciecha w Działdowie (1970-1980) i wicedziekan dekanatu lidzbarskiego od $1966 \mathrm{r}$.

17 Ks. Kazimierz Żbikowski - kapłan diecezji płockiej, proboszcz w Żurominie w latach 1958-1984.

18 Ks. Kazimierz Pawłowski - kapłan diecezji płockiej, proboszcz w Węgrze w latach 1970-1996.

19 Ks. Jan Radomski - kapłan diecezji płockiej, proboszcz w Cieksynie w latach 1967-1977.

20 Ks. Stefan Płoski - kapłan diecezji płockiej, proboszcz w Lutocinie w latach 1964-1985.

${ }^{21}$ Ks. Mieczysław Hościłowicz - kapłan diecezji chełmińskiej, proboszcz w Rybnie Pomorskim w latach 1961-1983.

d Błędnie wpisano: Zalewski.

22 Ks. Stefan Zaleski - kapłan diecezji płockiej, proboszcz w Bieżuniu w latach 1969-1997, dziekan (1987-1990) i wicedziekan żuromiński (1990-1997).

${ }^{23}$ Ks. Wiesław Wiśniewski - kapłan diecezji płockiej, proboszcz parafii w Sulerzyżu w latach 19661977.

24 Ks. Tadeusz Trzciński - kapłan diecezji płockiej, proboszcz w Kuczborku (1945-1985), wicedziekan (1946-1958) i dziekan żuromiński (1958-1981).

25 Ks. Józef Molęda - kapłan diecezji płockiej, proboszcz w Zielonej Mławskiej (1962-1984). 


\section{Przebieg rozmów indywidualnych przeprowadzonych w terminie od 15-}

\subsubsection{5 r.}

1. Zaplanowano zgodnie z planem w terminie 15-30 października br. przeprowadzić rozmowy indywidualne z grupą księży katechetów i kandydatów na katechetów; około 30-35 księży. Listę zaproszonych ustalono na Zespole Wojewódzkim. Rozmowy postanowiono przeprowadzić w Wydziale d/s Wyznań w/g szczegółowego, oddzielnie opracowanego harmonogramu.

2.

\begin{tabular}{|l|c|c|c|c|}
\hline \multicolumn{1}{|c|}{ Treść } & Ogółem & $\begin{array}{c}\text { W tym: } \\
\text { Katecheci } \\
\text { posiadający } \\
\text { umowy }\end{array}$ & $\begin{array}{c}\text { administratorzy } \\
\text { parafii nie posia- } \\
\text { dający umów }\end{array}$ & $\begin{array}{c}\text { Z liczby ogółem } \\
\text { członkowie } \\
\text { „Caritas” }\end{array}$ \\
\hline Zaproszono & 31 & 16 & 15 & 13 \\
\hline Obecnych & 30 & 16 & 14 & 13 \\
\hline Nieobecnych & 17 & 14 & 3 & 8 \\
\hline
\end{tabular}

3. Na rozmowy proszono dziennie od 3-4 osób w godzinach od 8.30-14.00. Nie przybył jeden ksiądz z powodu choroby.

4. W rozmowach poza sprawą punktów katechetycznych poruszano następujące zagadnienia:

- reforma administracji terenowej i jej znaczenie,

- osiągnięcia społeczno-gospodarcze kraju i woj[ewództwa] w ostatnim pięcioleciu,

- perspektywy dalszego rozwoju kraju, a w szczególności województwa,

- państwowa polityka wyznaniowa, zwłaszcza stosunki Państwo-Kościół,

- peregrynacja obrazu [Matki Boskiej Częstochowskiej] w woj[ewództwie] ciechanowskim,

- inne zagadnienia lokalne odnoszące się do pracy i zainteresowań księży, a mające wpływ na lojalizację duchowieństwa.

5. Należy dodać, iż z innych wyznań odnowiono umowy na nauczanie religii z 4 duchownymi: pastorem ewangelickim i 3 administratorami parafii mariawickich. Łącznie więc zawarto 21 umów.

6. Wnioski i uwagi wysunięte przez księży w czasie rozmów:

- w życiu codziennym jest za dużo pijaństwa, chuligaństwa i społecznej obojętności,

- występuje często w naszym życiu marnotrawstwo, brak poczucia odpowiedzialności, słaba dyscyplina pracy zwłaszcza w budownictwie,

- w praktyce lekarskiej nadużywa się prawa przerywania ciąży; lekarze powinni w większym stopniu prowadzić pracę wyjaśniającą w tej kwestii,

- brak często poszanowania dobra społecznego,

- brak w sprzedaży odpowiedniej ilości ciągników i dobrych jakościowo maszyn dla rolników. 


\section{Ogólne uwagi i wnioski:}

1. Spotkanie zbiorowe Wojewody z duchowieństwem w dniu 12 listopada br. oceniamy jako udane, na którym osiągnięto zakładane cele zamierzenia. Tym bardziej należy je pozytywnie ocenić, że:

- wzięli w nim udział niemal wszyscy zaproszeni dziekani, wśród których są również znani z nielojalnego stosunku do władz państwowych,

- aktywny był udział w spotkaniu większości zaproszonych księży, z tym również dziekanów, ponieważ 10, czyli około 50 \% obecnych zabierało głos w dyskusji,

- dyskutanci w swych wypowiedziach niemal wszyscy w serdecznych słowach dziękowali za zaproszenie, podkreślali potrzebę tego rodzaju okresowych spotkań i wymiany informacji,

- dobra była atmosfera spotkania, wypowiedzi dyskutantów miały charakter pozytywny, akcentowali oni szczególnie ogólne sprawy społeczne swych środowisk, sprawy i potrzeby kościelne traktowali jako drugorzędne. W dyskusji nie było akcentów agresywnych i pretensji.

Spotkanie należy ocenić jako dobre i udane, ponieważ na tym terenie, za wyjątkiem byłego powiatu działdowskiego /diecezja chełmińska/ nie było tradycji organizowania spotkań zbiorowych.

Ponadto w wyniku spotkania oraz przeprowadzonych rozmów indywidualnych:

2. nastąpiło zbliżenie przedstawicieli duchowieństwa z władzami wojewódzkimi, znalazło to wyraz w podziękowaniach licznych dyskutantów za zaproszenie na spotkanie i zapoznanie z problematyką nowego województwa.

3. Wymieniono zdania i poglądy na aktualne tematy interesujące obie strony.

4. Ukazano duchowieństwu dorobek społeczno-gospodarczy ostatnich lat oraz zapoznano z perspektywą dalszego rozwoju kraju i województwa.

5. Dokonano w pewnej mierze wyłomu w zakazie Episkopatu w sprawie kontaktowania się duchownych z władzami państwowymi.

6. Głębiej poznano stanowiska księży w interesujących nad sprawach.

7. Nastąpiło ugruntowanie przekonania, że Ojczyzna jest jednakowo droga wszystkim Polakom niezależnie od ich poglądów, wierzeń i przekonań.

8. Powstały przesłanki do dalszych kontaktów duchowieństwa z władzami państwowymi i nawiązania współpracy $w$ poczynaniach społeczno-gospodarczych i wychowaniu społeczeństwa.

\section{Zał. 1}

\section{Wykonano w 5 egzemplarzach}

Egz. Nr 1 - Urząd do Spraw Wyznań w Warszawie

Egz. Nr 2 - K[omitet] W[ojewódzki] PZPR

Egz. nr 3 - KW MO Wydział IV

Egz. $\mathrm{Nr} 4-5-\mathrm{a} / \mathrm{a}^{\mathrm{e}}$

Źródło: AAN, Urzqd d/s Wyznań w Warszawie, sygn. 125/66, k. 250-259, oryginat, mps.

e Po prawej stronie podłużna pieczq̨tka: Dyrektor Wydziału d/s Wyznań mgr Władysław Milanowski i odręczny podpis. 


\section{Nr 3}

1975 października 24, Płock - Informacja ze spotkania administratorów parafii z terenu województwa płockiego z wojewoda płockim Kazimierzem Janiakiem, odbytego w dniu 21 października $1975 \mathrm{r}$.

\section{Poufne}

\section{Informacja}

Egz. nr 1

o spotkaniu Tow[arzysza] Kazimierza Janiaka ${ }^{1}$, Wojewody Płockiego, $\mathrm{z}$ administratorami parafii woj[ewództwa] płockiego, odbytego w dniu 21 października 1975 r.

\section{Przygotowania organizacyjne}

Spotkanie zostało poprzedzone opracowaniem koncepcji organizacyjnej.

W dniu 14 października wyłoniono, po konsultacjach, grupę 69 księży, których postanowiono zaprosić do Wojewody. Kierowano się przy tym rozeznaniem dotychczasowych postaw poszczególnych księży wobec władz, ich pozycją w diecezji, obecnością w placówkach, służbowymi i prywatnymi wyjazdami, głównie za granicę oraz aktualnym stanem spraw w toku, o których załatwienie ubiegają się administratorzy. Liczebność grupy, przy założeniu, że miejscem spotkania powinna być siedziba Urzędu Wojewódzkiego, determinowały warunki lokalowe. Sala obrad w Urzędzie może pomieścić maksymalnie 70 osób. Przy tym zakładano możliwość zaproszenia następnej grupy o ile uzasadni to frekwencja i atmosfera pierwszego spotkania.

Postanowiono, że zaproszenie do księży wyśle Wojewoda, podając w nim ogólny cel spotkania i nie kryjąc równocześnie jego zbiorowego charakteru. Dla każdego zaproszonego przygotowano imienne zaproszenie. wymieniając jego funkcję, godności kościelne i tytuły naukowe, jeżeli posiada. Wypisano je indywidualnie, na papierze z nadrukiem urzędowym „Wojewoda Płocki”, bardzo starannie na maszynie /odpis zaproszenia w załączeniu/ z datą 13 października.

Zespół oceniający tok przygotowań zakładał, że księża zwrócą się do Kurii z zapytaniem o stanowisko w tej sprawie. Przebieg wcześniejszego spotkania Wojewody z b[isku]p[em] Bogdanem Sikorskim² i późniejsze reperkusje tego faktu wśród duchowieństwa katolickiego diecezji płockiej, nasuwały tezę o możliwości pewnej neutralizacji tego ostatniego. Postanowiono wykorzystać sprzyjające okoliczności i związać swobodę działania miejscowego ordynariusza, deklarującego swą lojalność wobec Wojewody, przez powiadomienie go o zamiarze zaproszenia księży do Urzędu Wojewódzkiego. Wykorzystano również okoliczności wcześniej

Kazimierz Janiak - wojewoda płocki w latach 1975-1977.

Biskup Bogdan Marian Sikorski - duchowny pochodzący z archidiecezji poznańskiej, w latach 1964-1988 biskup płocki, od 1984 r. przekazał - z polecenia Stolicy Apostolskiej - władzę biskupowi Zygmuntowi Kamińskiemu, administratorowi apostolskiemu „sede plena”, zachowując jedynie tytuł ordynariusza płockiego. 
zaplanowanej narady z naczelnikami miast i gmin. Otrzymali oni w kopertach zaproszenia dla administratorów parafii położonych w poszczególnych gminach z równoczesnym pouczeniem co do sposobu postępowania. Wojewoda polecił naczelnikom, by poprosili do siebie tych administratorów, dla których otrzymali otwarte koperty, wręczyli im przesyłki z delikatnym podkreśleniem, że ksiądz ma tę szczególną okazję zapoznania się bezpośredniego z Wojewodą i skalą problemów naszego, nowo utworzonego województwa. Narada z naczelnikami odbyła się w dniu 16 października. W tym samym dniu miała miejsce rozmowa telefoniczna Wojewody z Ks. Prałatem dr Zdzisławem Piechną ${ }^{3}$, Wikariuszem Generalnym Kurii Płockiej. Ordynariusz jeszcze nie urzędował po powrocie z Rzymu. Sufragan ${ }^{4}$ przebywa za granicą. Ksiądz Piechna zapewnił wojewodę, że przekaże b[isku]p[owi] Sikorskiemu treść rozmowy. Rychło też napływające informacje potwierdziły prawdziwość jego zapewnienia, jak i trafność przewidywań obliczonych na co najmniej neutralizację postawy b[isku]pa.

Naczelnicy wręczyli księżom zaproszenia w dniach 17 i 18 października. Ze zwięzłych informacji telefonicznych, przekazanych przez nich tut[ejszemu] Wydziałowi do Spraw Wyznań, wynikało, że zaproszenia zostały przyjęte, aczkolwiek część księży zastrzegało się, że przyjdą po uzyskaniu zezwolenia Kurii. Księża płoccy, zaproszeni do Prezydenta Płocka celem wręczenia im zaproszeń w dniu 17 października w godzinach przedpołudniowych, ujawnili, że wcześniej byli u b[isku]pa Sikorskiego i zalecił im udział w spotkaniu. „Skoro Pan Wojewoda prosi księży i uprzedził mnie wcześniej o tym, nie można czynić mu afrontu" miał się wyrazić wobec pytających o zgodę księży. Z informacji uzyskanych nieco później innym kanałem wynikało, że b[isku]p miał zalecić księżom wysunięcie wobec gospodarza spotkania postulatów o przekazanie Katedrze Płockiej kielicha i pateny Konrada Mazowieckiego oraz wyprowadzenia z pomieszczeń Wyższego Seminarium Duchownego Szkoły nr 3. Postulaty te nie zostały jednak wysunięte na spotkaniu.

Starannie, aczkolwiek dyskretnie, przygotowano miejsce spotkania. Z sali usunięto wszelkie elementy dekoracyjne. Na ścianie, za „stołem prezydialnym” pozostawiono Godło Państwa na tle biało-czerwonej flagi.

Wojewoda przyjął księży kawą lub herbatą, według wyboru, kruchymi ciastkami, owocami i sokami pitnymi. Stworzyło to nastrój skromnej, intymnej gościnności. Od wejścia do Urzędu opiekowali się księżmi dyskretnie ale oficjalnie pracownicy Wydziału do Spraw Wyznań, kierując ich do szatni a następnie do sali - miejsca spotkań. Na godzinę 11.00 opiewało zaproszenie. Pierwsi uczestnicy spotkania przybyli przed 10.00. Z zaciekawieniem zapoznali się z tablicami informacyjnymi w Urzędzie, pytali o rozmieszczenie Wydziałów, a nawet imiennie

Ks. Zdzisław Piechna - kapłan diecezji płockiej, w latach 1966-1977 wikariusz generalny diecezji płockiej.

4 Chodzi o biskupa Jana Wosińskiego - kapłana diecezji płockiej, w latach 1962-1964 administratora diecezji płockiej, a następnie biskupa pomocniczego/sufragana i wikariusza generalnego (1964-1991). 
o obecnych pracowników Urzędu Wojewódzkiego, przeniesionych tu służbowo z byłych powiatów. Zainteresowanym udzielono niezbędnych informacji.

Wcześniej uzgodniono, że Wojewoda zaproponuje wyjazd księży do Mazowieckich Zakładów Petrochemicznych celem zwiedzenia kombinatu. Uzależniono jednak ten wyjazd od zgody i zainteresowania uczestników spotkania. Poczyniono jednak uprzednio niezbędne przygotowania zabezpieczające możliwość realizacji tej propozycji.

\section{Przebieg spotkania}

Punktualnie o godzinie 11.00 Wojewoda wszedł na salę witając najpierw zebranych ogólnym „dzień dobry - witam księży”. Zebrani księża wstali z miejsc. Wojewoda następnie podszedł do każdego z osobna, podając mu rękę i przyjmując prezentację. Do końca prezentacji uczestnicy spotkania stali. Był to odruch absolutnie spontaniczny. Po zajęciu przez gospodarza w asyście dyrektora Wydziału do Spraw Wyznań ${ }^{5}$ miejsca za stołem, siedli również zaproszeni. Wojewoda cały czas stojąc, krótko zapoznał swoich gości z celem spotkania, dodając do treści zaproszenia, że pragnie zapoznać duchowieństwo spełniające obowiązki wobec społeczności katolickiej z woj[ewodą] płockim, zaprezentować zaproszonym aktualne problemy województwa i perspektywy jego społeczno-gospodarczego rozwoju. Uznaje bowiem, że znajomość tej problematyki jest potrzebna wszystkim mieszkańcom województwa, w tym i duchowieństwu, które ma chyba takie same, jak my wszyscy, ambicje uczestnictwa w procesach integracji byłych powiatów w jeden wojewódzki organizm. W tym miejscu gospodarz zaproponował dla chętnych krótką wycieczkę do Mazowieckich Zakładów Petrochemicznych po zakończaniu rozmowy w Urzędzie Wojewódzkim. Taka prezentacja celów spotkania została przyjęta przez zebranych oklaskami.

Prezentację województwa wobec zebranych Wojewoda zaczął od decyzji władzy ustawodawczej, podjętej z inicjatywy Rządu PRL w sprawie zmian w podziale administracyjnym kraju i reformie struktury państwowej władzy terenowej. Uzasadnił racjami społeczno-gospodarczymi i przesłankami historycznymi powołanie województwa płockiego. Następnie podał charakterystykę ogólną województwa, omawiając kolejno: położenie, wielkość i warunki geograficzne, demografię, układy komunikacyjne, przemysł, rolnictwo i budownictwo. Zilustrował przy tym swoją relację ciekawymi zestawieniami liczb dotyczących województwa i kraju oraz charakteryzujących wielką dynamikę rozwoju społeczno-gospodarczego.

Poczesne miejsce przeznaczył mówca w swoim wystąpieniu dla osiągnięć oświaty i kultury z podkreśleniem troski władzy państwowej o zabytki, w tym i sakralne, stanowiące skarby ogólnonarodowego dorobku. Omówił zdobycze socjalne ludzi pracy, ze szczególnym podkreśleniem dorobku ostatnich pięciu lat, problemy rozwoju placówek służby zdrowia opieki nad dzieckiem i matką.

\footnotetext{
Obowiązki dyrektora Wydziału ds. Wyznań Urzędu Wojewódzkiego w Płocku pełnił w latach 1975-1985 Kazimierz Wielec (od 1984 r. jako dyrektor Wydziału Organizacyjnego).
} 
Problematykę tę Wojewoda prezentował w aspekcie dotychczasowych osiągnięć i w perspektywie planu do 1980 r. W swoim wystąpieniu mówca eksponował miejsce naszego kraju w Europie i świecie, wzrost autorytetu Polski wśród innych narodów, jej rolę w umacnianiu pokoju światowego. Zwrócił uwagę na potrzebę uszanowania prawa, ładu, porządku i dyscypliny społecznej, koniecznych dla zabezpieczenia naszych osobistych zamierzeń. Wyraził przy tym przekonanie, że księża świadomi są tej potrzeby, a swoją obywatelską postawą przyczyniają się do utrwalenia dobrych stosunków w naszej wojewódzkiej społeczności. Wszyscy musimy mieć świadomość istnienia pewnego marginesu społecznego, który czasem zatruwa życie /opilstwo, złodziejstwo, marnotrawstwo, brak poszanowania mienia i godności drugiego człowieka/. W tym miejscu Wojewoda wskazał na potrzebę zwalczania tego zjawiska na płaszczyźnie wychowawczej, gwarantującej najlepsze wyniki, choć nie wykluczył użycia środków przymusu prawnego. Wspomniał o swoim spotkaniu z ordynariuszem płockim, podkreślając dobrą atmosferę tego spotkania. Wystąpienie zakończył zapewnieniem, że liczy na księży, na ich lojalność wobec władzy państwowej i siebie jako przedstawiciela rządu, na poszanowanie praw obowiązujących w kraju, na zgodną, obywatelską postawę. Wystąpienia księża wysłuchali ze skupieniem i przyjęli je spontanicznymi oklaskami.

O głos poprosił ks. prałat mgr Seweryn Wyczałkowski ${ }^{6}$ - dziekan płocki. „Znamy Wojewodę od dawna i szanujemy go. To dobrze, że zostaliśmy tu zaproszeni. Skorzystaliśmy bardzo wiele. Przedstawiono nam sprawy poważne i ciekawe. Nie zawsze tak było. Cieszymy się, że Pan Wojewoda poinformował wcześniej naszego Biskupa Płockiego o spotkaniu z nami. Jest w tym dowód zaufania i poszanowania godności ludzkiej. Czujemy dziś, że mamy nie tylko wspólnych przodków, ale i współcześnie zbliżyliśmy się do siebie. Dziękuję w imieniu własnym i zebranych księży za to przyjęcie, tak miłe i serdeczne”. Zebrani wstali i oklaskami wyrazili swoją aprobatę. Wojewoda poprosił, by siedli i zapytał, kto jeszcze pragnie się wypowiedzieć.

O głos poprosił ks. Wacław Szczepański ${ }^{7}$ - proboszcz parafii Trębki. Zgłosił postulat pod adresem władz państwowych o objęcie wszystkich księży ubezpieczeniem. „Już wszyscy korzystają z ubezpieczeń i zaopatrzenia emerytalnego. Pozostali tylko księża poza tym prawem. Może by tak i księżom, jako Polakom miłującym Ojczyznę, przyznać te prawa. Proboszcz posiadający gospodarstwo korzysta z ubezpieczenia jako rolnik. A co z tymi, którzy ziemi nie posiadają? Są często w ciężkim położeniu”.

Ksiądz Antoni Podleś ${ }^{8}$ - proboszcz parafii Płock-Biała. „Część mojej parafii to tereny kombinatu. Pod budowę wywłaszczono lub wykupiono ziemię. Nie cała

${ }_{6} \quad$ Ks. Seweryn Wyczałkowski - kapłan diecezji płockiej, proboszcz parafii św. Bartłomieja w Płocku (1958-1985) i dziekan płocki (1958-1982).

7 Ks. Wacław Szczepański - kapłan diecezji płockiej, w latach 1945-1957 wikariusz z prawem następstwa, a w latach 1957-1979 proboszcz parafii w Trębkach.

8 Ks. Antoni Podleś - kapłan diecezji płockiej, w latach 1968-1982 proboszcz parafii w Białej koło Płocka. 
powierzchnia jest zabudowana. Widzę około 30 ha ziemi przejętej od rolników. Dobra to ziemia, urodzajna, a leży odłogiem. Czy nie można by jej uprawić? Tyle przecież się mówi o wykorzystaniu każdego hektara. Można znaleźć chętnych do uprawy tej ziemi”... „Osiągnięcia kraju są wielkie, imponujące wręcz. Ale czy nie pora już zlikwidować te kolejki za mięsem? U mnie, w Białej, ubito 15 tuczników, a w sklepie znalazły się tylko dwa schaby i dwie karkówki. Jak to jest?”... „Rolnicy chcą nabywać na użytek własny kombajny. Czy jest możliwość zakupu w takiej formie?”... „Szerzy się demoralizacja. Obejmuje również młodzież. Jest na terenie mojej parafii hufiec OHP [Ochotnicze Hufce Pracy]. To trudna młodzież. Czasem ucieka do OHP, bo nie chce jej się uczyć. Różny tam jest element. Za dużo sobie pozwalają. Robią bimber nawet. Podobno znaleziono tam zacier. Czy nie można by zapewnić kontaktów z nimi dla księdza. Przynajmniej dla tych którzy wyraziliby taką chęć?”.

Ksiądz dr Henryk BRUNKA ${ }^{9}$ - proboszcz parafii św. Stanisława Kostki w Płoc$\mathrm{ku}$ - podziękował za zezwolenie na budowę kościoła parafialnego. „Ludzie przypisują tę decyzję nowym władzom wojewódzkim. Księża i cała społeczność katolicka Płocka i nie tylko Płocka, są wdzięczni władzom za tę decyzję, a którą długo czekano, ale ona jest dziś wielką radością. Zachowamy na zawsze wdzięczność dla władz".

Ksiądz dr Tadeusz KUKLA ${ }^{10}$ - proboszcz parafii Zyck Polski prosił o modernizację odcinka drogi Słubice-Zyck o bardzo kiepskiej nawierzchni.

Ksiądz Kanonik Jan KRAWCZYŃSKI ${ }^{11}$ - dziekan sierpecki. „Nie depczcie przeszłości ołtarzy, choć sami piękniejsze macie wznieść" - rozpoczął cytatem swoje wystąpienie. On wie o opiece władz konserwatorskich nad zabytkami w tym i sakralnymi. „Ale kto teraz będzie tę opiekę sprawował? Władze warszawskie, czy płockie? Bo w kościele Św[iętego] Ducha w Sierpcu odkryto polichromię gotycką. Jest ona bardzo zniszczona. W ciężkich warunkach grozi jej całkowita zagłada. Mieli to zrobić studenci. Mimo obietnic od trzech lat nic się nie robi. Jak ochronić to dobro kultury?”... „Władze lokalne nie chcą księżom przydzielać materiałów budowlanych. Nawet wówczas, gdy chodzi o bardzo małe ilości, na drobne remonty. Czy nie można tego zmienić? Po co po dwa worki cementu jechać aż do województwa? To nawet ośmiesza naczelnika gminy".

Ksiądz Henryk MARKUSZEWSKI ${ }^{12}$, proboszcz parafii Duninów. „Odczuwa się na wsi brak paszy. Poprawić zaopatrzenie w paszę, a wzrośnie hodowla. Szczególnie drobne gospodarstwa odchodzą od tuczu trzody z braku paszy".

$9 \quad$ Ks. Henryk Brunka SDB - kapłan salezjanin, w latach 1972-1978 proboszcz parafii św. Stanisława Kostki w Płocku.

10 Ks. Tadeusz Kukla - kapłan diecezji siedleckiej, inkardynowany do diecezji płockiej w 1965 r., w latach 1975-1977 proboszcz w Zycku.

11 Ks. Jan Krawczyński - kapłan diecezji płockiej, w latach 1962-1987 proboszcz parafii farnej w Sierpcu i dziekan sierpecki.

12 Ks. Henryk Markuszewski - kapłan diecezji płockiej, w latach 1965-1984 proboszcz parafii w Duninowie Nowym. 
Ksiądz Stefan ROSTKOWSKI ${ }^{13}$, proboszcz parafii Kaszewy Kościelne. Na przystanku autobusowym, naprzeciw „Miflexu” [w Kutnie] brak ściany. Nie ma kto naprawić, ale ludzie będą marźli w zimę. Prosi Wojewodę o interwencję.

Ksiądz Jerzy Bednarowicz ${ }^{14}$, proboszcz parafii Plecka Dąbrowa. „Nie ma połączenia z województwem. Trudno się dostać do Płocka. Czy nie można by temu zaradzić?".

Wojewoda w krótkich słowach udzielił wyjaśnień, zapewniając zainteresowanych, że ich postulaty przekaże wydziałom Urzędu Wojewódzkiego do zbadania i w miarę możliwości do realizacji. Oczywiście tylko te, które dadzą się zrealizować. Podziękował zaproszonym za udział w spotkaniu i zapewnił, że wychodząc naprzeciw postulatom księży, w przyszłości też znajdzie dla nich czas na podobną rozmowę. „Najlepszą formą podziękowania ze strony księży będzie dla mnie spełnienie przekonania, że zostanie umocniona nasza praworządność państwowa. Rozstaję się z księżmi w przeświadczeniu, że spotkanie było pożyteczne i potrzebne dla obu stron, a nasze kontakty będą nacechowane poszanowaniem praworządności”. Wojewoda poinformował zebranych, że sprawy bieżące, dotyczące księży i parafii, załatwia z jego upoważnienia obecny dziś dyrektor Wydziału do Spraw Wyznań. Do niego więc należy zgłaszać się ze sprawami indywidualnymi.

Ta część spotkania zakończyła się o godz. 13.00.

\section{Frekwencja}

Zaproszono 69 księży. Wszyscy zaproszenia przyjęli. Nie przybyli na spotkanie: Ksiądz mgr Franciszek Pytel ${ }^{15}$ - Dyrektor Towarzystwa Salezjańskiego w Czerwińsku z powodu wyjazdu do Berlina, ksiądz Kazimierz Cichecki ${ }^{16}$ proboszcz parafii Woźniaków i ksiądz Kazimierz Jarząbek ${ }^{17}$, proboszcz parafii w Czerwińsku - Salezjanie usprawiedliwili swoją nieobecność ważną konferencją w Zakonie. Księża Stanisław Barszczewski ${ }^{18}$ - proboszcz parafii Miłonice i Jerzy Zieliński ${ }^{19}$ - proboszcz parafii Goleszyn - przybyli bez zaproszeń do Wojewody nakłonieni do przyjazdu spontanicznie przez sąsiadów, innych uczestników spotkania.

13 Ks. Stefan Rostkowski - kapłan archidiecezji warszawskiej, w latach 1971-1981 proboszcz parafii w Kaszewach Kościelnych.

14 Ks. Jerzy Bednarowicz - kapłan archidiecezji warszawskiej, w latach 1973-1981 proboszcz parafii w Pleckiej Dąbrowie.

15 Ks. Franciszek Pytel SDB - ksiądz salezjanin, do 1979 r. dyrektor administracyjny w Czerwińsku.

16 Ks. Kazimierz Cichecki SDB - ksiądz salezjanin, w latach 1975-1981 proboszcz parafii w Woźniakowie.

17 Ks. Kazimierz Jarząbek SDB - ksiądz salezjanin, w latach 1972-1980 proboszcz parafii w Czerwińsku.

18 Ks. Stanisław Barszczewski - kapłan archidiecezji warszawskiej, od 1960 r. proboszcz parafii w Miłonicach.

19 Ks. Jerzy Zieliński - kapłan diecezji płockiej, w latach 1960-1977 proboszcz parafii w Goleszynie. 
Z diecezji p ł o c k i e j zaproszono 53 księży. Przybyło 52. Dziekanów zaproszono 7. Wszyscy przybyli. Na 8 księży członków „Caritas” wszyscy obecni.

Z diecezji w a r s z a w s k i e j zaproszono 9 księży, w tym dwóch dziekanów i dwóch członków „Caritas”. Obecni wszyscy.

Z diecezji ł ó d z k i e j zaproszono 6 księży, w tym 1 członka „Caritas”. Przybyli wszyscy.

W spotkaniu uczestniczyło ogółem 68 księży.

\section{Pobyt w Mazowieckich Zakładach Rafineryjno-Petrochemicznych w Płocku}

W wyjeździe wzięło udział 58 księży. Dowieziono ich wcześniej przygotowanymi autokarami. Księżom towarzyszyli w odrębnych autokarach Wojewoda i dyrektor Wydziału do Spraw Wyznań. Niektórzy nie mogli, z uwagi na porę, wziąć udziału w wyjeździe. Niemal wszyscy indywidualnie usprawiedliwiali swoją absencję konkretnymi przyczynami - wyjazd, pogrzeb, wcześniej zaplanowane zajęcia. Wyczuwało się początkowo pewne zażenowanie i jakby tajoną obawę. Uczestnicy wzajemnie się na siebie oglądali. Do autokarów, ustawionych przed Urzędem Wojewódzkim, podchodzili z pewnym ociąganiem, rozglądając się, czy nie zostaną w mniejszości. W kombinacie, gdy poczuli się w licznej grupie, życzliwie przyjęci przez gospodarzy, reprezentowanych przez członka kierownictwa Tow[arzysza] mgr Bolesława Witkowskiego ${ }^{20}$, poczuli się znów swobodniej. Zaproszono nas do sali, w której ustawiona jest makieta całego kombinatu, plastycznie obrazująca wszystkie instalacje. Uczestnikom rozdano informatory opisujące historię i osiągnięcia kombinatu.

Do stołu podano kawę. W tym czasie mgr Bolesław Witkowski w ciągu godziny objaśniał wielkość, skalę produkcji oraz znaczenie tej wielkiej inwestycji dla gospodarki narodowej i środowiska. Na księżach zrobiło to duże wrażenie. Przewodnik eksponował umiejętnie wyniki współpracy i znaczenie pomocy Związku Radzieckiego dla rozwoju kombinatu. Opisywał zwięźle, ale dostępnie nawet dla laików, funkcje poszczególnych instalacji, źródło ich zakupu, czas montażu, skalę produkcji i stopień nowoczesności w odniesieniu do osiągnięć światowych. Zainteresowanie rosło. Trzeba było aż przypomnienia Wojewody, że księża mają jeszcze przed sobą odległą drogę do parafii, a czas ucieka. Zadano przewodnikowi liczne pytania, na które z dużą swobodą odpowiadał. Księża żywo komentowali między sobą doznane wrażenia w drodze do autokarów, które powiozły ich w głąb kombinatu. W autokarach wyjaśnień udzielali przewodnicy w wyciecze po kombinacie. Zatrzymano się przy jednej z instalacji, gdzie udostępniono im zwiedzenie ośrodka sterowania procesem produkcyjnym. Wycieczka zakończyła się po godzinie 15.00. Uczestnicy spotkania podziękowali Wojewodzie i gospodarzom za umożliwienie im dostępu do zakładów, które znali dotąd tylko z opisów i opowiadań.

Wojewoda pożegnał księży przed kombinatem i odjechał do dalszych zajęć służbowych, przewidzianych na ten dzień. Księża, wysiadając w najdogodniej-

${ }^{20}$ Bolesław Witkowski - od 1959 r. zastępca dyrektora płockiej Petrochemii ds. ekonomicznych. 
szych dla siebie miejscach z autokarów, rozjechali się następnie do swoich parafii. Z zachowania wyczytać było łatwo, że czuli się usatysfakcjonowani. Indywidualnie dziękowali za zgotowane im przyjęcie, a niektórzy wręcz przyznawali, że jechali z pewną tremą, dla której nie znajdują teraz żadnego uzasadnienia.

\section{Spostrzeżenia ogólne i wnioski}

1. Celem spotkania było pogłębienie oddziaływania na proces lojalizacji księży w stosunku do władzy państwowej. Zarówno zasięg - liczebność grupy, jak i przebieg spotkania świadczą, że cel zasadniczy został osiągnięty. Wzięło w nim udział 57,2\% ogółu administratorów parafii z województwa płockiego, w tym z diecezji płockiej 65,8\%, łódzkiej 54,5\% i warszawskiej 33,3\%. Uczestnicy zachowali się w stosunku do Wojewody z poszanowaniem i godnością należną przedstawicielowi Rządu.

2. Grupa została zaprezentowana publicznie. Księża przybyli do Urzędu wojewódzkiego w większości przed wyznaczoną godziną, pozostawali na korytarzu wobec interesantów i pracowników Urzędu, mimo że mieli dostęp do sali. Nie ukrywali swojej obecności. Nie zaproszono wszystkich członków „Caritas”, by podkreślić uniwersalność spotkania. Licznie uczestniczyli w wyjeździe do zakładu pracy. Wyczuwało się wyraźnie odprężenie z chwilą, kiedy tam przekonali się, że wyjazd ten nie ma charakteru pokazu publicznego. Może to mieć praktyczne znaczenie dla podobnych inicjatyw w przyszłości.

3. O powodzeniu inicjatywy przesądziła w dużej mierze trafność oceny warunków poprzedzających spotkanie, sprawność organizacyjna, precyzja współdziałania uczestników zespołu przygotowującego, szybkość działania i dyskretne ale skuteczne włączenie do akcji w odpowiednim momencie naczelników gmin i miast.

4. Trafna w skutkach okazało się posunięcie obliczone na neutralizację ordynariusza poprzez rozmowę telefoniczną Wojewody z przedstawicielem Kurii o zamiarze odbycia spotkania.

5. Dobrą atmosferę samego spotkania osiągnął Wojewoda swoją osobowością, swobodą wejścia otwartego, bezpośredniego, ale w majestacie sprawowanego urzędu, co w tym środowisku musi robić wrażenie. Spotęgowało ją następnie swobodne, wygłoszone z pamięci, ładną, poprawną polszczyzną przemówienie do księży. Podobało się to uczestnikom spotkania i zaimponowało im.

6. W tych warunkach wydaje się celowe zaproszenie poszczególnych administratorów parafii przez Wojewodę. Faktem jest, że można być mniej pewnym ich postawy, ale są w mniejszości i powinni przybyć. Działanie i w tym wypadku winno być sprawne i szybkie. Wymaga jednak nieco innego przygotowania. Musi być kontynuacja, bo wojewoda uprzedził, że nie mógł zaprosić na raz wszystkich z uwagi na ograniczoność miejsca, ale nie tymi samymi formami. Odpada bowiem element całkowitego zaskoczenia. 
7. Należy w krótkim czasie dokonać pogłębionej oceny wyników spotkania w oparciu o informacje napływające z terenu na temat interpretacji tego faktu przez księży i miejscowych hierarchów.

\section{Wykonano w 5 egz[emplarzach]}

Egz. Nr 1 - Urząd do Spraw Wyznań

Egz. Nr $2-$ j. w.

Egz. nr 3 - KW PZPR w Płocku

Egz. nr 4 - KW MO w Płocku

Egz. Nr $4-5-\mathrm{a} / \mathrm{a}$

Wyk. K. W. ${ }^{\mathrm{a}}$

Druk J. M. ${ }^{\mathrm{b}}$

Dnia 24.X.1975 r. ${ }^{\mathrm{c}}$

Źródło: AAN, Urzq̨d d/s Wyznań w Warszawie, sygn. 125/66, k. 193-203, oryginał, mps.

\section{$\operatorname{Nr} 4$}

1980 styczeń 10, Ciechanów - Załącznik do sprawozdania o sytuacji wyznaniowej i działalności Wydziału d/s Wyznań w Ciechanowie w 1979 r. zawierający dane na temat stosunków wyznaniowych $w$ województwie ciechanowskim $w$ latach 1975-1979

Podstawowe dane, obrazujące kształtowanie się stosunków wyznaniowych w pięcioleciu 1957-1979 /dotyczy wyłącznie Kościoła rzymskokatolickiego/

\begin{tabular}{|l|l|r|r|r|r|r|}
\hline Lp. Wyszczególnienie & 1975 & 1976 & 1977 & 1978 & 1979 \\
\hline 1. & Placówki kościelne & 104 & 105 & 107 & 109 & 110 \\
& a. parafie razem & & & & & \\
& b. nowoutworzone parafie & -- & 1 & 2 & 2 & 1 \\
& - legalnie & --- & --- & --- & --- & --- \\
$\quad$ - nielegalnie & --- & --- & -- & -- & -- \\
& c. domy zakonne męskie & 23 & 19 & 18 & 20 & 20 \\
& d. domy zakonne żeńskie & 329 & 328 & 322 & 320 & 299 \\
& e. punkty katechetyczne razem & 204 & 203 & 199 & 198 & 184 \\
\hline - w tym pomieszczeniach prywatnych & & & & & \\
\hline 2. & Duchowieństwo i zakonnice & 168 & 177 & 172 & 187 & 186 \\
& a. księża razem & 168 & 176 & 172 & 187 & 186 \\
& - diecezjalni & -- & 1 & --- & --- & --- \\
& - zakonni & 135 & 135 & 135 & 125 & 126 \\
& b. zakonnice razem & 5 & 14 & 10 & 14 & 17 \\
& c. alumni seminariów diecezjalnych i zakonnych razem & 5 & 14 & 10 & 14 & 17 \\
\hline
\end{tabular}

\footnotetext{
a Adnotacja o autorze pisma: K[azimierz] W[ielec].

b Adnotacja o osobie sporzq̨dzajqcej/przepisującej na maszynie pismo: J[adwiga] M[entlewiak].

c Po prawej stronie podłużna pieczq̨tka: Dyrektor Wydziału mgr Kazimierz Wielec $i$ odręczny podpis.
} 


\begin{tabular}{|c|c|c|c|c|c|c|}
\hline 3. & $\begin{array}{l}\text { Ruch kadrowy proboszczów i administratorów parafii } \\
\text { a. nowo mianowani proboszczowie i adm[inistratorowie] } \\
\text { par[afii] } \\
\text { b. zastrzeżenia wydziału do projektów nominacji } \\
\text { c. ślubowanie proboszczów } \\
\quad \text { - uzyskane } \\
\text { - zaległe }\end{array}$ & --- & $\begin{array}{r}-- \\
6\end{array}$ & 20 & $\begin{array}{r}5 \\
---\end{array}$ & $\begin{array}{c}4 \\
---\end{array}$ \\
\hline 4. & $\begin{array}{l}\text { Praca z duchowieństwem } \\
\text { a. spotkania z biskupami } \\
\text { b. spotkania z duchowieństwem } \\
\quad \text { - indywidualne } \\
\text { - zbiorowe } \\
\text { c. liczba umów o nauczanie religii }\end{array}$ & $\begin{array}{l}39 \\
12 \\
15\end{array}$ & $\begin{array}{r}185 \\
--- \\
18\end{array}$ & $\begin{array}{r}228 \\
--- \\
22\end{array}$ & $\begin{array}{r}264 \\
--- \\
24\end{array}$ & $\begin{array}{r}293 \\
1 \\
24\end{array}$ \\
\hline 5. & $\begin{array}{l}\text { Wyjazdy zagraniczne duchowieństwa } \\
\text { a. księża wyjeżdżający za granicę } \\
\text { b. odmowy wydania paszportów }\end{array}$ & $\begin{array}{c}27 \\
---\end{array}$ & $\begin{array}{c}24 \\
---\end{array}$ & $\begin{array}{r}14 \\
2\end{array}$ & $\begin{array}{c}23 \\
---\end{array}$ & $\begin{array}{r}8 \\
---\end{array}$ \\
\hline 6. & $\begin{array}{l}\text { Stowarzyszenie Katolików „Caritas” } \\
\text { a. członkowie koła księży „Caritas” } \\
\text { b. liczba zebrań koła księży }\end{array}$ & $\begin{array}{c}14 \\
---\end{array}$ & $\begin{array}{c}18 \\
---\end{array}$ & $\begin{array}{c}19 \\
---\end{array}$ & $\begin{array}{c}18 \\
---\end{array}$ & $\begin{array}{l}19 \\
---\end{array}$ \\
\hline 7. & $\begin{array}{l}\text { Obiekty sakralne i budownictwo } \\
\text { a. kościoły i kaplice razem } \\
\text { b. wydane zezwolenia na budownictwo sakralne razem } \\
\text { - budowa nowych kościołów i kaplic } \\
\text { - odbudowa, przebudowa, rozbudowa } \\
\text { - remonty } \\
\text { c. wydane zezwolenia na budownictwo kościelne /pleba- } \\
\text { nie, domy zakonne, inne obiekty/ razem } \\
\text { - budowa nowych obiektów } \\
\text { - odbudowa, przebudowa, rozbudowa } \\
\text { - remonty } \\
\text { d. samowole budowlane razem } \\
\text { - obiekty sakralne } \\
\text { - inne obiekty }\end{array}$ & \begin{tabular}{r|}
139 \\
4 \\
- \\
1 \\
3 \\
5
\end{tabular} & $\begin{array}{r}139 \\
6 \\
- \\
1 \\
5 \\
6\end{array}$ & \begin{tabular}{r|}
139 \\
9 \\
- \\
1 \\
8 \\
13
\end{tabular} & $\begin{array}{r}139 \\
12 \\
- \\
3 \\
9 \\
11\end{array}$ & $\begin{array}{r}139 \\
14 \\
- \\
1 \\
13 \\
14\end{array}$ \\
\hline 8. & $\begin{array}{l}\text { Nieruchomości kościelne } \\
\text { a. nowo nabyte nieruchomości razem } \\
\text { - przez jednostki kościelne } \\
\text { - przez osoby duchowne /księży i zakonnice/ }\end{array}$ & $\begin{array}{l}- \\
- \\
-\end{array}$ & $\begin{array}{l}- \\
- \\
-\end{array}$ & $\begin{array}{l}- \\
- \\
-\end{array}$ & $\begin{array}{l}- \\
- \\
-\end{array}$ & $\begin{array}{l}2 \\
2 \\
-\end{array}$ \\
\hline
\end{tabular}

\section{Dodatkowe wyjaśnienia do sprawozdania statystycznego - część „C” Do pkt. 2 podpunkt ,c" i „,d”a}

Podane w zestawieniu dane mogą być nieścisłe. Na terenie województwa ciechanowskiego nie ma bowiem seminariów duchownych diecezjalnych i zakonnych, dlatego w podpkt. d nie możemy podać rzeczywistego stanu alumnów w poszczególnych latach. W ppkt. c podane liczby osób - według naszego rozeznania - podjęły naukę w następujących seminariach diecezjalnych i zakonnych:

\footnotetext{
a W oryginale podpunkty „C” i „d” zapisane bez cudzysłowu.
} 


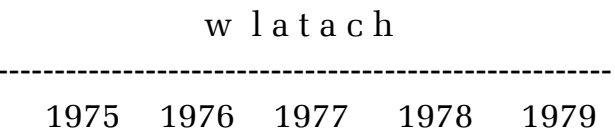

1. WSD Płock

$\begin{array}{lllll}5 & 9 & 10 & 11 & 12\end{array}$

2. WSD Częstochowa

3. WSD Siedlce

4. WSD Warszawa

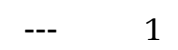

5. WSD Wrocław

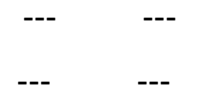

--- --- 1

6. WSD Zakonu OO.

Redemptorystów w Tuchowie

7. WSD Zakonu OO. Sercanów

w Krakowie

8. WSD Zakonu Jezuitów

w Krakowie

9. WSD Zakonu

OO. Pallotynów w Ołtarzewie

10. Kolegium Jezuickie w Kaliszu

11. WSD Zakonu OO. Werbistów

w Pieniężnie

$$
-
$$$$
-
$$$$
1
$$$$
\begin{array}{lll}
-- & 2 & 1
\end{array}
$$$$
\begin{array}{lllll}
-- & -- & -- & -- & 1
\end{array}
$$

12. WSD Zakonu Towarzystwa

Salezjańskiego w Lądzie

\section{Do pkt. 6 podpunkt b}

Członkowie Z[wiązku] K[atolików] „Caritas” z terenu województwa ciechanowskiego są obsługiwani przez Zarząd Oddziału Rejonowego w Warszawie. Zebrania organizowane są zwykle w Warszawie lub Nadarzynie

\section{Do pkt. 7 podpunkt d}

Dane liczbowe dotyczące nielegalnej budowy figur i krzyży przydrożnych. W okresie sprawozdawczym nie stwierdzono przypadków nielegalnego budownictwa innych obiektów sakralnych lub kościelnych.

Źródło: AAN, Urzq̨d d/s Wyznań w Warszawie, sygn. 127/73, k. 85-87, oryginał, mps. 


\section{Nr 5}

1980 styczeń 9, Płock - Załącznik do sprawozdania o sytuacji wyznaniowej i działalności Wydziału d/s Wyznań w Płocku w 1979 r. zawierajq̨y dane na temat stosunków wyznaniowych $w$ województwie płockim w latach 1975-1979

aPodstawowe dane, obrazujące kształtowanie się stosunków wyznaniowych w pięcioleciu 1957-1979/dotyczy Kościoła rzymskokatolickiego/

\begin{tabular}{|c|c|c|c|c|c|c|}
\hline Lp. & Wyszczególnienie & 1975 & 1976 & 1977 & 1978 & 1979 \\
\hline 1. & $\begin{array}{l}\text { Placówki kościelne } \\
\text { a. parafie razem } \\
\text { b. nowoutworzone parafie } \\
\quad \text { - legalnie } \\
\quad \text { - nielegalnie } \\
\text { c. domy zakonne męskie } \\
\text { d. domy zakonne żeńskie } \\
\text { e. punkty katechetyczne razem } \\
\text { - w tym pomieszczeniach prywatnych } \\
\end{array}$ & \begin{tabular}{r|r}
119 \\
1 \\
1 \\
-- \\
6 \\
29 \\
259 \\
170 \\
\end{tabular} & $\begin{array}{r}119 \\
--- \\
-- \\
-- \\
6 \\
29 \\
260 \\
140 \\
\end{array}$ & $\begin{array}{r}119 \\
--- \\
-- \\
-- \\
6 \\
29 \\
269 \\
149 \\
\end{array}$ & \begin{tabular}{r|}
119 \\
--- \\
--- \\
-- \\
6 \\
29 \\
245 \\
125 \\
\end{tabular} & $\begin{array}{r}119 \\
1 \\
-- \\
1 \\
6 \\
29 \\
260 \\
136\end{array}$ \\
\hline 2. & $\begin{array}{l}\text { Duchowieństwo i zakonnice } \\
\text { a. księża razem } \\
\quad \text { - diecezjalni } \\
\text { - zakonni } \\
\text { b. zakonnice razem } \\
\text { c. alumni seminariów diecezjalnych i zakonnych razem } \\
\text { d. przyjęci na I kurs WSD } \\
\end{array}$ & \begin{tabular}{r|r}
272 \\
224 \\
48 \\
294 \\
88 \\
18
\end{tabular} & $\begin{array}{r}278 \\
229 \\
49 \\
298 \\
95 \\
19\end{array}$ & $\begin{array}{r}277 \\
228 \\
49 \\
301 \\
95 \\
18\end{array}$ & $\begin{array}{r}281 \\
227 \\
54 \\
306 \\
103 \\
19 \\
\end{array}$ & $\begin{array}{r}278 \\
231 \\
47 \\
310 \\
117 \\
29\end{array}$ \\
\hline 3. & $\begin{array}{l}\text { Ruch kadrowy proboszczów i administratorów parafii } \\
\text { a. nowo mianowani proboszczowie i adm[inistratorowie] } \\
\text { par[afii] } \\
\text { b. zastrzeżenia wydziału do projektów nominacji } \\
\text { c. ślubowanie proboszczów } \\
\text { - uzyskane } \\
\text { - zaległe } \\
\end{array}$ & $\begin{array}{r}-- \\
3 \\
---\end{array}$ & $\begin{array}{r}3 \\
1 \\
---\end{array}$ & $\begin{array}{r}11 \\
6\end{array}$ & $\begin{array}{r}10 \\
8\end{array}$ & $\begin{array}{r}-- \\
9 \\
--\end{array}$ \\
\hline 4. & $\begin{array}{l}\text { Praca z duchowieństwem } \\
\text { a. spotkania z biskupami } \\
\text { b. spotkania z duchowieństwem } \\
\quad \text { - indywidualne } \\
\quad \text { - zbiorowe } \\
\text { c. liczba umów o nauczanie religii } \\
\end{array}$ & $\begin{array}{r}102 \\
2 \\
28 \\
\end{array}$ & $\begin{array}{r}192 \\
--- \\
30\end{array}$ & $\begin{array}{r}215 \\
1 \\
29 \\
\end{array}$ & $\begin{array}{r}231 \\
--- \\
30\end{array}$ & $\begin{array}{r}220 \\
--- \\
32 \\
\end{array}$ \\
\hline 5. & $\begin{array}{l}\text { Wyjazdy zagraniczne duchowieństwa } \\
\text { a. księża wyjeżdżający za granicę } \\
\text { b. odmowy wydania paszportów }\end{array}$ & $\begin{array}{c}59 \\
---\end{array}$ & $\begin{array}{l}22 \\
---\end{array}$ & $\begin{array}{c}28 \\
---\end{array}$ & $\begin{array}{c}28 \\
---\end{array}$ & $\begin{array}{l}30 \\
--\end{array}$ \\
\hline 6. & $\begin{array}{l}\text { Stowarzyszenie Katolików „Caritas” } \\
\text { a. członkowie koła księży „Caritas” } \\
\text { b. liczba zebrań koła księży }\end{array}$ & $\begin{array}{l}20 \\
10\end{array}$ & $\begin{array}{l}20 \\
10\end{array}$ & $\begin{array}{l}18 \\
12\end{array}$ & $\begin{array}{l}18 \\
11\end{array}$ & $\begin{array}{l}19 \\
10\end{array}$ \\
\hline
\end{tabular}

a W lewym górnym rogu pieczq̨tka podłużna: Urząd Wojewódzki w Płocku Wydział do Spraw Wyznań ul. Kolegialna 13, 09-400 Płock. 


\begin{tabular}{|c|c|c|c|c|c|c|}
\hline 7. & $\begin{array}{l}\text { Obiekty sakralne i budownictwo } \\
\text { a. kościoły i kaplice razem } \\
\text { b. wydane zezwolenia na budownictwo sakralne razem } \\
\text { - budowa nowych kościołów i kaplic } \\
\text { - odbudowa, przebudowa, rozbudowa } \\
\text { - remonty } \\
\text { c. wydane zezwolenia na budownictwo kościelne /pleba- } \\
\text { nie, domy zakonne, inne obiekty/ razem } \\
\text { - budowa nowych obiektów } \\
\text { - odbudowa, przebudowa, rozbudowa } \\
\text { - remonty } \\
\text { d. samowole budowlane razem } \\
\text { - obiekty sakralne } \\
\text { - inne obiekty }\end{array}$ & $\begin{array}{r}4 \\
3 \\
1 \\
1 \\
--- \\
--- \\
--- \\
\end{array}$ & $\begin{array}{r}9 \\
8 \\
--- \\
1 \\
--- \\
--- \\
--- \\
\end{array}$ & $\begin{array}{r}8 \\
--- \\
1 \\
7 \\
--- \\
--- \\
--- \\
\end{array}$ & $\begin{array}{r}13 \\
3 \\
2 \\
8 \\
--- \\
--- \\
--- \\
\end{array}$ & $\begin{array}{r}3 \\
2 \\
1 \\
--- \\
--- \\
--- \\
--- \\
\end{array}$ \\
\hline 8. & $\begin{array}{l}\text { Nieruchomości kościelne } \\
\text { a. nowo nabyte nieruchomości razem } \\
\text { - przez jednostki kościelne } \\
\text { - przez osoby duchowne /księży i zakonnice/ }\end{array}$ & $\begin{array}{l}--- \\
--- \\
---\end{array}$ & $\begin{array}{l}--- \\
--- \\
---\end{array}$ & $\begin{array}{l}--- \\
--- \\
---\end{array}$ & $\begin{array}{r}1 \\
1 \\
---\end{array}$ & $\begin{array}{r}1 \\
1 \\
---\end{array}$ \\
\hline
\end{tabular}

Źródło: AAN, Urzqdd d/s Wyznań w Warszawie, sygn. 127/74, k. 53-54, oryginał, mps.

\section{Nr 6}

1983 styczeń 31, Płock - Sprawozdanie o sytuacji wyznaniowej i działalności Wydziału d/s Wyznań w województwie płockim w 1982 r.

Płock, dnia 31 stycznia 1983 r. ${ }^{\mathrm{a}}$

\section{Sprawozdanie}

bPoufne

Egz. nr 1

o sytuacji wyznaniowej i działalności Wydziału do Spraw Wyznań w 1982 r.

W okresie istnienia województwa płockiego ukształtowała się tradycja poprawnych stosunków między władzami wojewódzkimi a miejscową władzą diecezjalną Kościoła Katolickiego. Wytrzymały one też próbę jakości w ostatnich dwóch latach. Biskup i Kuria generalnie nie ulegali pokusie wykorzystywania trudności, które przeżywały władze, dla umacniania swoich pozycji w oparciu o nowe sojusze polityczne. Stąd nie doszło tu do publicznego eksponowania takich więzi politycznych ze strony kościelnej, o których z góry dało się powiedzieć, że nie będą miłe władzom. Zbliżenia „konieczne” nie zawsze były przy najbliższej okazji usprawiedliwiane i obwarowywane zapewnieniami o niezmiennej lojalności wobec partnera wiodącego w ramach istniejących stosunków. Wprowadzenie sta-

\footnotetext{
Data dzienna i rok wpisany ręcznie.

b W lewym górnym rogu pieczątka podłużna: Urząd Wojewódzki w Płocku Wydział do Spraw Wyznań ul. Kolegialna 13, 09-400 Płock. tel. 241-68 i liczba dziennika: Wz.pf/6/83.
} 
nu wojennego przyjęte zostało przez miejscowy Kościół z powagą i spokojem, bez demonstracji rezerwy i uprzedzeń. Przed dalej posuniętymi wyrazami solidarności z władzą państwową w tym względzie powstrzymywały Biskupa ${ }^{1}$ i jego najbliższych współpracowników obawy przed utratą więzi z centralnymi władzami kościelnymi. Nie aprobował on bowiem anarchii i rozprzężenia, a do liderów opozycji żywił nieufność i obawiał się ich. Okoliczności sprawiły, że w dniu 14 grudnia 1981 r. byłem w Kurii² i rozmawiałem kilka godzin z Biskupem przy udziale kierowniczego aparatu urzędniczego ${ }^{3}$. Wtedy to właśnie mówił otwarcie, że spodziewał się takiego obrotu spraw, że jest to logiczne następstwo wydarzeń. Niepokoiła go tylko możliwość zaistnienia krwawych incydentów.

a/ W 1982 r. odbyły się dwa spotkania oficjalne Wojewody Płockiego ${ }^{4}$ z Biskupem Płockim. Nadto spotkali się oni w ramach zespołu międzyresortowego do spraw usunięcia skutków powodzi w rejonie Płocka. Biskup przyjął propozycję udziału w pracy tego zespołu i uczestniczy w jego posiedzeniach. Jest to też okazją do sporadycznych telefonicznych kontaktów między nim a Wojewodą. Ma pretekst. U progu roku odbyła się znana uroczystość święcenia zabytkowych drzwi w Katedrze ${ }^{5}$. Cała sprawa drzwi jest do dziś jednym z istotniejszych elementów w tworzeniu pożądanej atmosfery między stronami stałego dialogu. Biskupowi zresztą od lat nie zdarzyło się wystąpienie publiczne, które budzić by mogło dezaprobatę. Biskup pomocniczy ${ }^{6}$ pozostaje w cieniu tych stosunków. Nie wykracza on poza ramy obowiązków duszpasterskich i kanonicznych. Są to ramy ograniczone specyfiką wewnętrznych układów w Kurii.

Drugą płaszczyznę stosunków określają nasze układy z urzędem diecezjalnym. Są one poprawne i w zasadzie bezkonfliktowe. Biskup oficjalnie zaleca swoim urzędnikom troskę o zachowanie tej poprawności. Stronę kościelną reprezentuje w tej płaszczyźnie wikariusz generalny Kurii, ks. Władysław Lis ${ }^{7}$. Ale na życzenie Wydziału przychodzą też inni funkcjonariusze Kurii. Nie było przypadku odmo-

1 Chodzi o biskupa płockiego Bogdana Mariana Sikorskiego - duchownego pochodzącego z archidiecezji poznańskiej, w latach 1964-1988 biskupa płockiego, który w 1984 r. przekazał - z polecenia Stolicy Apostolskiej - władzę biskupowi Zygmuntowi Kamińskiemu, administratorowi apostolskiemu „sede plena”, zachowując jedynie tytuł ordynariusza płockiego.

2 Ówczesnym dyrektorem Wydziału ds. Wyznań Urzędu Wojewódzkiego w Płocku był Kazimierz Wielec, który pełnił swe obowiązki w latach 1975-1985 (od 1984 r. jako dyrektor Wydziału Organizacyjnego Urzędu Wojewódzkiego).

3 Z innych źródeł wiemy, że w czasie wspomnianego spotkania w Kurii Diecezjalnej w Płocku, poza biskupem płockim i dyrektorem Wydziału ds. Wyznań, obecny był m.in. ks. Władysław Lis, wikariusz generalny diecezji płockiej, oraz ks. Romuald Rudziński, sekretarz Wydziału Artystyczno-Budowlanego Kurii Płockiej.

4 Chodzi o wojewodę płockiego Antoniego Bielaka, w latach 1975-1979 pełniącego obowiązki wicewojewody, a w latach 1980-1990 wojewody płockiego.

5 Jest to nawiązanie do uroczystego przekazania kopii brązowych Drzwi Płockich z XII w. oraz ich poświęcenia, którego dokonał 28 lutego 1982 r. w Płocku prymas Polski, arcybiskup Józef Glemp.

6 Chodzi o biskupa Jana Wosińskiego - kapłana diecezji płockiej, w latach 1962-1964 administratora diecezji płockiej, a następnie biskupa pomocniczego i wikariusza generalnego (1964-1991).

7 Ks. Władysław Lis - kapłan diecezji płockiej, oficjał sądu biskupiego (1968-1977) i wikariusz generalny diecezji płockiej (1977-1984). 
wy udziału w spotkaniu z ich strony. Bywają wyjątki od reguły alienowania się Biskupa od spraw urzędniczych. Zdarzyło się bowiem, że włączył się on w moje spotkanie z ks. Władysławem Lisem w Kurii pod pretekstem osobistego rekomendowania wniosku o erygowanie nowej wiejskiej parafii. Wniosku, który i bez tego by przeszedł. Wierzy w życzliwość Wydziału dla swojej postawy i stąd bez ryzyka podjął bezpośredni kontakt. Okazał mi też swoją życzliwość wyraźnie. Miły to gest. Znamionuje chyba, że i oni są zadowoleni ze swego udziału w utrwalaniu ładu społecznego. Kuria nie ma w strukturze organizacyjnej przybudówki do spraw niesienia pomocy „,internowanym, uwięzionym i prześladowanym”, mimo nieustannych nacisków na powołanie takiej komisji ${ }^{8}$ Nie oznacza to, że grupa ludzi z tzw. opozycji pozostawiona jest bez pomocy z tamtej strony. Otrzymują oni tę pomoc niejako od kuchni, nieoficjalnie, od kleru parafialnego. Taki też miała charakter dość głośna sprawa paczek świątecznych dla czołówki opozycyjnej. Fakt, że paczki te przygotowano i dzielono w prywatnym mieszkaniu, z jednej strony potwierdza tezę o defensywności poczynań Kurii w tym względzie, z drugiej zaś w ogóle umożliwiał organom MO dotarcie do źródła podziału. W sprawie umoczył rękę Dyrektor Wydziału Duszpasterskiego w Kurii ${ }^{9}$, organizator pielgrzymki do Częstochowy, która też nie zachowała deklarowanego charakteru. Były rozmowy. Zgłosiliśmy swoje zastrzeżenia. Po tamtej stronie istotnie wyciągnięto pewne nauki z tych incydentów. Ukoronowaniem incydentu był okólnik Biskup w sprawie darów, który całą sprawę ceduje na parafie.

b/ Generalnie kler diecezjalny w województwie nie daje wieku dowodów do interwencji z racji naruszeń norm prawa i innych zasad współżycia społecznego. Było kilka wyjątków. Młodzi księża: Jan Cegłowski ${ }^{10}$, Tadeusz Łebkowski ${ }^{11}$, Jan Kaźmierczak ${ }^{12}$, Stanisław Ziółkiewicz ${ }^{13}$ obnosili się publicznie ze swoją opozycyjnością wobec władz. Dwaj z nich: Tadeusz Łebkowski i Jan Kaźmierczak uczestniczyli w działaniu nielegalnych struktur organizacyjnych. Wszyscy oni są już w parafiach poza województwem ${ }^{14}$. Oprotestowanie ich poczynań sprawiło,

${ }_{8} \quad$ W 1982 r. został powołany komitet pomocy przy Wydziale Duszpasterskim Kurii Diecezjalnej w Płocku, a jego pracami kierował ks. Wacław Gapiński, pełniący obowiązki dyrektora wspomnianego wydziału.

9 Chodzi o ks. Wacława Gapińskiego, kapłana diecezji płockiej, w latach 1970-1986 dyrektora Wydziału Duszpasterskiego Kurii Diecezjalnej w Płocku.

10 Ks. Jan Cegłowski - kapłan diecezji płockiej, w latach 1980-1982 wikariusz parafii św. Bartłomieja w Płocku, a w latach 1982-1985 wikariusz w Przasnyszu.

11 Ks. Tadeusz Łebkowski - kapłan diecezji płockiej, wikariusz parafii św. Stanisława BM w Mławie w latach 1982-1986, w latach 1976-1982 wikariusz parafii św. Jana Chrzciciela w Płocku i kapelan „Solidarności”.

12 Ks. Jan Kaźmierczak - kapłan diecezji płockiej, w latach 1980-1982 wikariusz parafii św. Benedykta na Radziwiu.

13 Ks. Stanisław Ziółkiewicz SDB - kapłan salezjanin, pracujący w parafii św. Stanisława Kostki w Płocku w latach 1978-1982.

14 W 1982 r. biskup Sikorski przeniósł ks. Jana Cegłowskiego do Przasnysza (województwo ostrołęckie), ks. Tadeusza Łebkowskiego do Mławy (województwo ciechanowskie), ks. Jana Kaźmierczaka do Lipowca Kościelnego (województwo ciechanowskie), a przełożeni zakonni przenieśli ks. Stanisława Ziółkiewicza SDB do parafii w Sępopolu (województwo olsztyńskie). 
że władza kościelna usunęła ich z pola konfliktu. Jest to grupa księży „prywatnie” niechętnych władzy. Trzeba się liczyć, że okoliczności mogą ich uaktywnić. Nie jest to liczna grupa, ale jej istnienie nakazuje zachowanie czujności.

Do parafii Głogowiec, administrowanej przez Archidiecezją Warszawską, przeniesiono ks. Mariana Lipskiego ${ }^{15}$, wyniesionego ostatnio za „zasługi” w konfliktach do godności kanonika. Z tym zaczynają się kłopoty. Nie ma on jednak na razie szerszego uznania w oczach miejscowego kleru. Nominacja nie ma zgody Wydziału /nie było wniosku/. A działalność polityczną księdza oprotestowano w Kurii.

Cała reszta stosunków z klerem nie podlega zasadniczym odchyleniom od norm, jeżeli nie wchodzić w szczegóły.

c/ Pax z trudem zlepia się wewnętrznie. Dotąd nie osiągnęła ich działalność granic z okresu poprzedzającego wprowadzenie stanu wojennego. Są obecni w PRON, usiłują odbudować swe skromne wpływy. ChSS nieobecny. Polski Związek Katolicko-Społeczny ledwo egzystuje, przy niewielkim zasięgu działania. Dotąd nie udało się ich centrali pozyskać tu szerszego aktywu, mimo poparcia ze strony części kleru. Nie uzyskali zezwolenia na organizowanie działalności na wsi. Były podejmowane $\mathrm{z}$ ich strony próby grupowania w środowisku wiejskim resztek „Solidarności” RI. Jak dotąd bez powodzenia.

d/ Mariawici, stanowiący największą po katolikach grupę wyznaniową, nie byli w stanie wykorzystać dla podkreślenia swej obecności w środowisku nawet tej szansy, jaką dała im akcja niesienia pomocy poszkodowanym przez powódź. Byli dysponentami darów. Starzeją się/kler, zakonnice/, spada dynamika ich działań. Wchodzą w wiek dożywania. Odłam z Felicjanowa chyba nic już nie jest stanie poderwać do życia. Korzystają z życzliwości władz, gdzie to jest możliwe i egzystują. Katolicki Kościół Mariawitów nie ma po b[isku]pie Kowalskim ${ }^{16}$ innego reprezentanta, który byłby w stanie uczestniczyć aktywniej w życiu środowiska. Biskup Kowalski zaś bywa gościem w Płocku, co też nie pozostaje bez wpływu na pozycję tego Związku w środowisku. Wreszcie traci ten Kościół bazę społeczną i to determinuje, że jest, jak jest.

Protestanci i prawosławni jeszcze istnieją. To wszystko, co można o nich powiedzieć.

Z „innymi wyznaniami” nie ma problemów politycznych. Jest problem ich obumierania. Nie równoważą w skali województwa w najmniejszym stopniu wpływów katolików rzymskich, co nie znaczy, że Wydział nie interesuje się ich działaniem. Ale nie wynikają z tego większe korzyści.

B. [!] Na przestrzeni minionego roku władze wojewódzkie - w sensie systemowym - nie określały się w stosunku do problemów polityki wyznaniowej. Tyle

\footnotetext{
Ks. Marian Lipski - kapłan archidiecezji warszawskiej, proboszcz parafii św. Wojciecha w Głogowcu w latach 1982-1998, kapelan podziemnej ,Solidarności”.

16 Chodzi o biskupa Stanisława Marię Tymoteusza Kowalskiego - biskupa naczelnego Kościoła Starokatolickiego Mariawitów w latach 1972-1997.
} 
tylko, że w przyjęty sposób załatwiano poszczególne problemy dotyczące tematu. Wydział nie uskarża się na możliwość docierania z problemami do kierownictwa politycznego i administracyjnego województwa. Trudno jednak mówić o szczególnych inicjatywach, bo chyba i pory ku temu nie było, a okoliczności nakazywały działać spokojnie, bez rozgłosu.

C. Funkcjonowanie Wydziały w minionym roku było trudniejsze niż kiedykolwiek, bardziej złożone ${ }^{17}$.

a/ Cele można dziś z łatwością komponować. A jak było?! Nie dopuścić do konfliktów! Taki był nakaz. A więc nastawienie na działania interwencyjne, doraźne, niesione przez rozwój wydarzeń, z usiłowaniem sprostania wymaganiom. Nie dopuścić do sojuszu Kościoła z opozycją! Ale to nie tylko cel Wydziału. Wydział został wpisany w realizację tego celu już w $1981 \mathrm{r}$.

b/ Oddziaływanie na postawy kleru poprzez wpływ na administrację kurialną. Wykorzystanie zaistniałych układów i dążeń tamtej strony do zachowania ugody dawało rękojmię skuteczności działania. W ten sposób utrzymana została zasada lojalności kościoła na terenie województwa, a nie tylko poszczególnych księży. Nie wymagało to nawet szczególnych „ustępstw”. Oczekiwania i postulaty strony kościelnej były wyważone i umiarkowane. Na miarę możliwości. Wyciszanie politykierów przez władze kościelne okazało się wystarczająco skuteczne. Czy to jest podrzucanie kłopotów sąsiadom? /Owe przemieszczanie młodych księży/. Nie sądzę, by tam zachowali oni tę samą aktywność. A rośnie fama, utrwala się przekonanie wśród księży o braku zapotrzebowania na opozycjonistów. Owszem, pewną popularność wśród księży można zarobić konfliktem z władzami. Władza kościelna jednak nie obroni takiego i ześle na peryferie diecezji, bo chce mieć spokój.

c/ Nie można się uskarżać na brak zapotrzebowania, a i zrozumienia też.

d/ Poza pewnymi kłopotami z konserwatorem zabytków, który demonstruje swój kosmopolityzm i trzeba uciekać się do arbitrażu przełożonych, Wydział nie napotyka trudności w tym względzie, z którymi nie można by sobie poradzić.

e/ Wystarczające. Choć powtarzają się zakusy na uszczuplenie etatów i lokali. Utrudnieniem jest istotne ograniczenie limitów samochodowych. Najpewniej i najtaniej byłoby docierać do księży pieszo! Zabiegi o środki w tym względzie stają się kłopotliwe.

Treść zawarta w punkcie „C” wydaje się stanowić odpowiedzi dyrektora Wydziału ds. Wyznań w Płocku na pytania formularzowe, które zapewne nadeszły z Urzędu ds. Wyznań w Warszawie. Znamy je m.in. z podobnego sprawozdania, jakie złożył dyrektor Wydziału ds. Wyznań Urzędu Wojewódzkiego w Ciechanowie (AAN, Urząd ds. Wyznań, sygn. 128/53, k. 64-67). Dotyczyły one następujących zagadnień (pytań): a) cele, jakie stawiał przed sobą Wydział w 1982 r.; b) ważniejsze poczynania Wydziału w sferze administrowania stosunkami wyznaniowymi; c) rola Wydziału w upowszechnianiu zasad polityki wyznaniowej; d) przejawy i efekty współpracy z innymi ogniwami aparatu państwowego; e) warunki organizacyjne i materialne działalności Wydziału; f) samoocena efektywności działania Wydziału; g) postulaty pod adresem władz centralnych. Natomiast dwa kolejne podpunkty („h” i „i”) mają charakter dodatkowej informacji dyrektora Kazimierza Wielca na temat spraw pracowniczych podległego mu wydziału oraz streszczają główne założenia i formy działalności Wydziału ds. Wyznań Urzędu Wojewódzkiego w Płocku w 1983 r. 
f/ Nie ma powodu do wyrzutów o nienadążanie za rozwojem wydarzeń. Nie zostały też popełnione poważniejsze błędy w działaniu, choć przez długi okres czasu byliśmy skazani wyłącznie na własne siły.

g/ Mimo wszystko mamy do czynienia z partnerem sterowanym - zwłaszcza w zakresie strategii działania - centralnie, jest on też zdyscyplinowany wewnętrznie w zakresie podstawowych pryncypiów, jak też nieźle poinformowany. Nie da się tak samo zdecydowanie powiedzieć o sytuacji w naszych szeregach. Był okres przerwy w kontaktach centrali z wydziałami. Naprawiono to w minionym roku. Ale jeszcze nie wróciliśmy do dawnych więzi. Polityki wyznaniowej nie da się robić wyłącznie kanałem administracyjnym i środkami służb wewnętrznych. Wyobrażenie społeczeństwa o treści tej polityki kształtuje nasz przeciwnik, lub kontrpartner, jeżeli ktoś woli. On jest wciąż bardziej wiarygodny w oczach znacznego odłamu społeczeństwa. Marzy się taka sytuacja, kiedy zacznie on mieć kłopoty z postępową, niezależną prasą, ujmującą się za społecznym interesem ludzi świeckich, o laickim programie działania; kiedy jednostka ludzka, że wyrażę to ich tonem, będzie miała szansę stawać w szranki z instytucją kościelną w obronie swych interesów. Teraz nie staje, bo jej nie obronimy. My nie dysponujemy bronią małego i średniego kalibru. Mamy same armaty. A bywają sytuacje, kiedy dobry kij byłby bardziej przydatny. Bardzo potrzebny jest mechanizm, który postawi państwo i jego administrację $\mathrm{w}$ roli arbitra $\mathrm{i}$ to nie koniecznie nastawionego wyłącznie na obronę jednej ze stron. Niepokoi zjawisko szerzącego się klerykalizmu wśród znacznej części aktywu partyjnego i kierowniczego aparatu administracyjnego. W tej sprawie potrzebna jest jasna wykładnia stanowiska partii na obecnym etapie rozwoju.

Z dostępnych informacji wynika, że katechizacji dzieci i młodzieży nadano w ostatnich latach w wielu ośrodkach duszpasterskich opozycyjnie polityczny charakter. Zasięg zjawiska trudny jest do precyzyjnego określenia. Ale nie jest mały. Razi nieporadne operowanie $\mathrm{w}$ propagandzie argumentem o sukcesach budownictwa sakralnego i kościelnego w ostatnich latach. Wybudowali więcej niż się spodziewali. Niech oni się chwalą. W telewizji brzmi to jak usprawiedliwienie. Informacje odczytywane są jak akt skruchy za lata ucisku. Chyba, że chcemy ludziom obrzydzić sukcesy tego budownictwa? Inwestorzy kościelni zaczynają go mieć dość tu i ówdzie. Nie ożywiajmy tematu. Ustały dopłaty do cen materiałów budowlanych, podrożało budownictwo i to skuteczniej ograniczy jego rozmiary niż inne czynniki. A swoją drogą odnosi się wrażenie, że całe zagłębie miedziowe wznoszono takim wysiłkiem tylko po to, by zapewnić świątyniom miedzianą blachę na dachy. Czy w tym względzie cena nie mogła by przyhamować zapędów? Tym bardziej, gdy miedź kładzie się na dachy obiektów o wątpliwych walorach zabytkowych.

h/ Z dniem 31 stycznia br. inspektor Wydziału przechodzi do pracy w KW $\mathrm{PZPR}^{18}$.

${ }_{18}$ Chodzi o Jana Jerzego Rysia, starszego inspektora wojewódzkiego pracującego w Wydziale do Spraw Wyznań Urzędu Wojewódzkiego w Płocku w latach 1976-1983, który przeszedł następnie do pracy w Wydziale Administracyjnym KW PZPR w Płocku. 
i/ Główne założenia to:

- Utrzymanie istniejącego stanu stosunków z instytucjami kościelnymi, pogłębienie procesu lojalizacji kleru wobec państwa, przeciwstawienie się poczynaniom wrogim politycznie.

- Przeciwdziałanie tendencjom do wykorzystywania struktur kościoła przez opozycyjne elementy polityczne. Umacnianie lojalnego wobec państwa nurtu w świeckich stowarzyszeniach ludzi wierzących.

- Służenie pomocą aparatowi państwowemu Urzędu Wojewódzkiego, instytucjom społecznym i aktywowi partyjnemu w uzyskiwaniu orientacji w zakresie celów wyznaniowej polityki partii i państwa.

- Przeciwdziałanie środkami prawno-organizacyjnymi tendencjom obliczonym na klerykalizację różnych sfer działalności publicznej.

Formy pracy muszą być elastyczne, każdorazowo dostosowane do zmieniającej się sytuacji.

Egz. Nr 1 - Urząd do Spraw Wyznań.

Egz. Nr $2-\mathrm{a} / \mathrm{a}^{\mathrm{c}}$

Źródło: AAN, Urząd d/s Wyznań w Warszawie, sygn. 128/80, k. 29-36, oryginał, mps.

\title{
Nr 7
}

1984 styczeń 27, Ciechanów - Sprawozdanie o sytuacji wyznaniowej i działalności Wydziału d/s Wyznań w województwie ciechanowskim w $1983 \mathrm{r}$.

${ }^{\text {aPoufne }}$

Egz. nr 1

\section{Sprawozdanie} \\ o sytuacji wyznaniowej i działalności \\ Wydziału do Spraw Wyznań w województwie \\ ciechanowskim z $1983 \mathrm{r}$.
}

\begin{abstract}
A. Charakterystyka rozwoju stosunków w sferze wyznaniowej
a/ Postawa i aktywność kurii biskupich oraz przejawy politycznego zaangażowania biskupów - oddziaływanie władz polityczno-administracyjnych

Na terenie województwa ciechanowskiego działają trzy kurie: Płocka /dominująca - 99 parafii/, Chełmińska /14 parafii/ i Warmińska z 1 parafią.

W $1983 \mathrm{r}$. kurie zajmowały w zasadzie stanowisko formalnie poprawne wobec władz państwowych. Nie notowano bowiem faktów naruszania obowiązującego
\end{abstract}

Po prawej stronie podłużna pieczq̨tka: Dyrektor Wydziału mgr Kazimierz Wielec i odręczny podpis.

a W lewym górnym rogu pieczątka podłużna Urząd Wojewódzki w Ciechanowie Wydział d/s Wyznań $i$ liczba dziennika Wz.Pf-18/84. 
porządku prawnego. W wystąpieniach publicznych biskupów i kurialistów nie stwierdzono istotniejszych akcentów politycznych, a zwłaszcza wyraźnie wrogich.

Swoistą interpretację dekretu z dnia 31 grudnia 1956 r. o organizowaniu i obsadzaniu stanowisk kościelnych ${ }^{1}$ odnotowano w kurii chełmińskiej, po objęciu tej diecezji przez bpa M[ariana] Przykuckiego². Otóż we wnioskach dot[yczących] zmiany na stanowiskach proboszczów, zamiast, jak przedtem pisano, że „...bp ma zamiar mianować...”, użyto formuły: „...zawiadamia, że mianował księdza... na stanowisko proboszcza....". Po pisemnym przypomnieniu, adresowanym do bpa, iż wspomniany „dekret nadal obowiązuje”, w kolejnych wnioskach kurii wrócono do poprzedniej formuły.

Przed zniesieniem stanu wojennego zaangażowanie polityczne biskupów i kurii ograniczało się w zasadzie do przekazywania proboszczom listów i komunikatów Episkopatu dot[yczącym] m.in. organizowania zbiórek na rzecz internowanych i skazanych, zapewnienia im opieki duszpasterskiej lub odprawiania nabożeństw w ich intencji. Własnej inicjatywy i większej aktywności w tych sprawach nie stwierdzono.

Aktywność i zaangażowanie biskupów i kurii w omawianym okresie koncentrowała się głównie w dwóch dziedzinach: przygotowania duchowieństwa parafialnego do organizowania tzw. duszpasterstwa rolników i nadal rozwijania budownictwa sakralnego i kościelnego. Szczególnie żywą działalnością w tym zakresie charakteryzuje się kuria płocka i osobiście bp B[ogdan] Sikorski ${ }^{3}$. Na temat duszpasterstwa rolników organizowano bowiem rejonowe konferencje duchowieństwa, obsługiwane przez kurialistów, którzy nie tylko wyjaśniali istotę tej nowej formy działalności Kościoła, ale jednoznacznie stwierdzali, iż jest to - obok pracy z dziećmi i młodzieżą - jedno z podstawowych zadań, wymagających pełnego zaangażowania proboszczów i wikariuszy w jego praktycznej realizacji. Ta problematyka dosyć szeroko była podejmowana w okresie ożywionej działalności Kościoła, podczas przygotowań i przebiegu II pielgrzymki papieża Jana Pawła II do Polski.

Druga dziedzina - budownictwo sakralne i kościelne - jak wynika z analizy wpływających wniosków, zwłaszcza do naczelników jednostek podstawowych, stało się w pewnym sensie „konikiem” bpa B[ogdana] Sikorskiego. Skrzętnie wy-

\footnotetext{
Chodzi o dekret Rady Państwa z 31 grudnia 1956 r. o organizowaniu i obsadzaniu stanowisk kościelnych (Dz.U. $1957 \mathrm{nr}$ 1, poz. 6).

2 Biskup Marian Przykucki - duchowny pochodzący z archidiecezji poznańskiej, biskup pomocniczy poznański (1974-1981), ordynariusz chełmiński (1981-1992), arcybiskup metropolita szczecińsko-kamieński (1992-1999). Od 1999 r. arcybiskup senior archidiecezji szczecińsko-kamieńskiej.

3 Biskup Bogdan Marian Sikorski - duchowny pochodzący z archidiecezji poznańskiej, w latach 1964-1988 biskup płocki, od 1984 r. przekazał - z polecenia Stolicy Apostolskiej - władzę biskupowi Zygmuntowi Kamińskiemu, administratorowi apostolskiemu „sede plena”, zachowując jedynie tytuł ordynariusza płockiego.
} 
korzystując sprzyjającą „aurę”, stworzoną m.in. Zarządzeniem $\mathrm{Nr} 47^{4}$, biskup z całą konsekwencją stara się realizować generalne wytyczne Episkopatu - parafia w miastach na każde 10 tys. mieszkańców, na wsi maksymalnie 5 km do kościoła lub kaplicy.

W czerwcu 1983 /przed przyjazdem papieża/ bp B[ogdan] Sikorski wystąpił do Wojewody $\mathrm{y}^{5}$ wnioskiem o zezwolenie na budowę nowego kościoła i erygowanie trzeciej parafii w Mławie ${ }^{6}$, prosząc o jego załatwienie w trybie pilnym, ponieważ pragnie w ten sposób uczcić doniosły fakt II pielgrzymki papieża do kraju ojczystego. Pisemna odpowiedź, iż wniosek może być ewentualnie rozważany - zgodnie z Zarządzeniem Nr 47 - na następną pięciolatkę /lata 1986-90/, była powodem starań bpa o spotkanie z Wojewodą, które odbyło się 20 sierpnia $1983 \mathrm{r}$.

Warto przy tym dodać, iż realizacji tych generalnych wytycznych podporządkowana jest również polityka kadrowa kurii. Proboszcz nie realizujący zaleceń bpa - nie zgłaszający wniosków budowlanych, nie podejmujący budowy lub opieszale wykonujący inwestycje - nie ma żadnych szans na uznanie, a przede wszystkim na przejście na lepszą, intratniejszą parafię. Na skutej tej presji ciągle wpływają wnioski na budowę nowych kaplic, punktów katechetycznych i innych obiektów kościelnych. Aktualnie, bez zbytniej przesady, można określić, iż Kościół Rzymskokatolicki stał się największym inwestorem w województwie.

Wspomniane wyżej spotkanie Wojewody z bpem B[ogdanem] Sikorskim, jakie odbyło się na prośbę bpa w dniu 20 sierpnia 1983 r. - w pewnym sensie inspirowane przez władze wojewódzkie - było sprzyjającą okazją do zwrócenia uwagi na negatywne postawy i działalność niektórych księży, szkalujących organa władzy, zwłaszcza zaś milicję i służbę bezpieczeństwa. Przedstawione przez Wojewodę konkretne zarzuty dotyczyły w szczególności ks. R[omualda] Jaworskiego - proboszcza nowej parafii w Płońsku , ks. Fr[anciszka] Gala - proboszcza z Glinojec$\mathrm{ka}^{8}$ i jego wikariusza ks. H[enryka] Lewandowskiego ${ }^{9}$, ks. T[adeusza] Łebkowskiego - wikariusza z Mławy ${ }^{10}$ i ks. A[ndrzeja] Zembrzuskiego - wikariusza z Żuromina ${ }^{11}$.

4 Chodzi o Zarządzenie Nr 47 Prezesa Rady Ministrów „Planowanie i realizacja inwestycji sakralnych oraz kościelnych" z dnia 24 listopada 1981 r.

5 Wojewodą był w tym czasie Jerzy Adam Wierzchowski (1926-1995), wojewoda ciechanowski w latach 1975-1987.

6 Chodzi o parafię pod wezwaniem Matki Bożej Królowej Polski w Mławie, erygowaną dopiero 4 listopada 1987 r. przez biskupa Zygmunta Kamińskiego.

7 Ks. Romuald Jaworski - kapłan diecezji płockiej, proboszcz parafii pod wezwaniem św. Maksymiliana Marii Kolbego w Płońsku w latach 1981-2001.

$8 \quad$ Ks. Franciszek Gal - kapłan diecezji płockiej, proboszcz parafii Glinojeck w latach 1980-1998.

$9 \quad$ Ks. Henryk Lewandowski - kapłan diecezji płockiej, wikariusz parafii w Glinojecku w latach 1981-1983.

10 Ks. Tadeusz Łebkowski - kapłan diecezji płockiej, wikariusz parafii św. Stanisława BM w Mławie w latach 1982-1986.

11 Ks. Andrzej Zembrzuski - kapłan diecezji płockiej, wikariusz parafii w Żurominie w latach 19821986. 
Księża ci wykorzystując uczucia wierzących zarówno z ambony, jak i w rozmowach z parafianami zmierzali wręcz do podsycania emocji, wywoływania napięć i sytuacji konfliktowych. Np. ks. T[adeusz] Łebkowski - „zesłany” z Płocka do Mławy za szczególne aktywną działalność i wspieranie ekstremy „Solidarności” - bez wiedzy i zgody dyrektora LO w Mławie wywiózł ponad 100 osobową grupę młodzieży do Warszawy na powitanie papieża. W listopadzie 1982 r., na zajęciach katechetycznych, nakłaniał młodzież do uczczenia rocznicy powstania „Solidarności” - zupełnym milczeniem na lekcjach. Utrzymuje on nadal żywe kontakty z byłymi działaczami tego związku. Ks. A[ndrzej] Zembrzuski angażował się szczególnie do zawieszania krzyży w szkołach, jest aktywnym i gorliwym propagatorem i organizatorem tzw. „oaz”.

Bp B[ogdan] Sikorski, po wysłuchaniu zarzutów, stwierdził, iż „,jest niemile zaskoczony przedstawionymi sprawami. Nie spodziewał się bowiem takiego przebiegu spotkania”. Zarzutów nie kwestionował. Zobowiązał się, że z tymi księżmi przeprowadzone zostaną rozmowy. Z proboszczami będzie rozmawiał osobiście, z pozostałymi Wikariusz Generalny - uczestniczący w spotkaniu ks. inf. Wł[adysław] Lis ${ }^{12}$. Ponadto ustalono, iż wikariusze ks. H[enryk] Lewandowski zostanie przeniesiony z Glinojecka i terenu woj[ewództwa] ciechanowskiego możliwie jak najszybciej, ks. T[adeusz] Łebkowski w późniejszym terminie. Jak wynika z naszego rozeznania rozmowy zostały przeprowadzone. Przyniosły one pewien efekt, ponieważ księża ci wyciszyli swoją negatywną działalność. Ks. H[enryka] Lewandowskiego przeniesiono na inny teren.

Głównym jednak tematem, z jakim biskup przybył na spotkanie była sprawa trzeciej parafii w Mławie i budowa tam nowego kościoła oraz plebanii. Ponadto b[isku]p podniósł sprawę przekazania b[yłej] kaplicy, tzw. „Magdalenki” w Pułtusku $^{13}$ i budynku poklasztornego $\mathrm{w}$ Ciechanowie ${ }^{14}$. W sprawach tych przyjęto następujące ustalenia: budowa nowego kościoła z plebanią w Mławie zostanie rozważona w czerwcu 1985 r., po złożeniu przez Kurię planu potrzeb budownictwa sakralnego i kościelnego na lata 1986-90, jednocześnie rozpatrzona będzie sprawa erygowania parafii. Ponadto Wojewoda zgodził się na wcześniejsze podjęcie przez Kurię starań o lokalizację i załatwienie formalności prawno-własnościowych terenu pod kościół i plebanię, ewentualne przekazanie „Magdalenki" może być rozważane w końcowym etapie budowy i oddania do użytku Centrum Polonijnego w Pułtusku, również w późniejszych latach można będzie wrócić do sprawy budynku poklasztornego w Ciechanowie.

Uogólniając, wydaje się zasadnym podkreślenie, iż w działalności kurii biskupich utrzymują się tendencje rewindykacyjne, rozbudowy bazy materialnej, roz-

12 Ks. Władysław Lis - kapłan diecezji płockiej, oficjał sądu biskupiego (1968-1977) i wikariusz generalny diecezji płockiej (1977-1984).

13 Chodzi o kaplicę pod wezwaniem św. Marii Magdaleny w Pułtusku, która należy do parafii pod wezwaniem św. Mateusza.

14 Chodzi o zabudowania po klasztorze augustianów w Ciechanowie, które należą do parafii pod wezwaniem św. Tekli. 
szerzenia i umacniania wpływów kościoła, zwłaszcza zaś na młodzież, ludność wiejską, nauczycieli, pracowników służby zdrowia.

\section{b/ postawa i aktywność duchowieństwa, przejawy szkodliwej działalności kleru}

Duchowieństwo parafialne w znacznej większości zachowuje lojalną postawę wobec władz i porządku prawnego PRL. Szczególnie wielu proboszczów, zwłaszcza starszych wiekiem należy ocenić pozytywnie za takt, rozwagę i umiar w podejmowaniu trudnych problemów nurtujących kraj i nasze społeczeństwo. W krytycznych okresach nierzadkie były przypadki nawoływania przez nich swych parafian do spokoju, rozwagi, przestrzegania prawa i odpowiedzialnej, solidnej pracy.

Nadal jednak, stosunkowo nieliczna grupa księży, zajmowała inną - agresywną postawę: totalnej krytyki władzy, przypisując jej wszelkie zło, kłopoty i trudności gnębiące nasz kraj i społeczeństwo. Z nielicznymi wyjątkami, była to ta sama grupa księży, którą szerzej scharakteryzowano w sprawozdaniu za rok 1982. Kilku z nich wymieniono wyżej w części a/ sprawozdania.

W swych wystąpieniach, najczęściej z ambony, księża ci atakują głównie milicję i służbę bezpieczeństwa, nie szczędząc przy tym niejednokrotnie niewybrednych epitetów. Tak np. ks. R[omuald] Jaworski - proboszcz z Płońska w kazaniu wygłoszonym w dniu 10. 07. [19]83 r. ostro piętnował nasz system polityczny, który - jego zdaniem - zniewala człowieka, zabija w nim wszelkie ludzkie uczucia, a szczególnie miłość bliźniego, swoje istnienie opiera przede wszystkim na siłach represyjnych. Jak stwierdził, potwierdzeniem tego był m.in. brutalny atak sił porządkowych podczas uroczystości z okazji Konstytucji 3 Maja na grupę osób związanych z prymasowskim ośrodkiem pomocy więzionym i cierpiącym. Kazanie zakończył konkluzją, iż „...panujący system nie uczy miłości bliźniego od dziecka i tylko kościół ze swoją nauką w obecnych czasach jest jedynym i godnym nauczycielem".

Podobne akcenty odnotowano w wystąpieniu rekolekcjonisty z zakonu Pallotynów w Otwocku, który 4 grudnia [19]83 r. w Łopacinie mówił m.in. ,...że w okresie stanu wojennego w Polsce wielu robotników w walce o sprawiedliwość oddało swe życie pod pałami milicyjnymi, ale zbrodniarze ci zostaną osądzeni nie tylko na ziemi, lecz także w niebiosach przez Boga”.

Na rekolekcjach w Żurominie w grudniu ub[iegłego] r[oku], jezuita O. Sylwester Jasiak z Kalisza głosił m.in., że „,...Bóg ma założone kajdany. Są ludzie wyposażeni w kajdany i pistolety, ale oni dla Boga są tylko pyłkiem. Bóg w konsekwencji zwycięży i rozliczy wszystkich”. Wołał też demagogicznie „aby wierni przychodzili do kościoła z legitymacją, ale nie czerwoną tylko z legitymacją wiary”. Nawiązując do historii Polski stwierdził, iż w naszych dziejach było nie 3 lecz 4 rozbiory Polski, a ten czwarty został dokonany przez Niemcy i ZSRR w 1939 r. Zaś „niepodległość odzyskaliśmy tylko i wyłącznie dzięki wierze w Boga i opiece Matki ${ }^{b}$ Boskiej Częstochowskiej”.

\footnotetext{
Zapisane mała litera.
} 
Podczas rekolekcji wielkopostnych w tejże samej parafii jezuita z Poznania o. Bolesław Sokołowski, poddał ostrej krytyce reformę gospodarczą, która - jak stwierdził - „polega jedynie na podwyżce cen”. Zarzucał również władzom, iż prowadzą politykę antykościelną i antyreligijną.

Szczególną złośliwość cechuje wystąpienie ks. P[iotra] Urbańskiego - proboszcza parafii Zielona gm. Kuczbork ${ }^{15}$. M.in. 4 grudnia ub[iegłego] r[oku] w kazaniu, mówiąc o pladze pijaństwa - złośliwie parafrazując Hymn Polski - powiedział ,,... jeszcze Rosja nie zginęła póki my pijemy. Car pozwalał na picie, Hitler również i obecnie także nie zabrania się, mimo deklaracji o zwalczaniu alkoholizmu. Dzięki temu długo Rosja istnieć będzie...”. Podjął również krytykę przebiegu procesu odnowy oraz środków masowego przekazu, zwłaszcza telewizji, a mianowicie stwierdził, m.in. „Zarzuca się księżom, że politykują, ale muszą prostować pewne fakty kłamliwie podawane przez środki masowego przekazu... Tyle się mówi o odnowie, a mamy ją już z głowy, bo wcześniej wybrano honorowego górnika, pierwszy był Gierek, a niedługo będziemy wybierać nowych budowniczych Polski Ludowej. Na górze przestawiło się kilka stołków, niektórzy się przesiedli i nadal będzie to samo".

Ks. J[an] Maroński - proboszcz parafii Nowe Miasto ${ }^{16}$ również w grudniu ub[iegłego] r[oku] podczas kazania wyraził swój stosunek do wiarygodności informacji podawanych w środkach masowego przekazu, a szczególnie w „Trybunie Ludu”, „Życiu Warszawy” i „Sztandarze Młodych”. Stwierdził, iż wiarygodność informacji trzeba podzielić na trzy kategorie. Do prawdziwych zaliczył tylko zamieszczane w nich nekrologi, których treść ,...podkreśla wielkość zasług osób będących kiedyś na usługach partii i rządu...”; prawdopodobne - to wiadomości sportowe i z życia kulturalnego; fałszywe - gross objętości tych gazet, dot[yczące] sytuacji gospodarczej, społ[eczno]-politycznej w kraju i o stosunkach międzynarowych. Jego zdaneim ,....mają one na celu wybielanie ułomności systemu socjalistycznego i kamuflowanie, niedbałości władz polityczno-administracyjnych wobec społeczeństwa".

W listopadzie i grudniu ub[iegłego] r[oku] w dwóch szkołach podstawowych na terenie gm. Ojrzeń w salach lekcyjnych rodzice zawiesili krzyże. Szczególnie brutalnie dokonano tego w Liberadzu, gdzie ubliżano nauczycielom i grożono im pobiciem /obie szkoły znajdują się na terenie parafii Glinojeck, której proboszczem jest ks. Fr[anciszek] Gal/. Sprawę z Liberadza skierowano do organów ścigania.

Przeciwdziałanie przejawom szkodliwej działalności kleru sprowadza się w zasadzie do rozmów profilaktyczno-ostrzegawczych. Prowadzone są one przez pracowników Wydziału, w nielicznych przypadkach przez Naczelników i pra-

\footnotetext{
Ks. Piotr Urbański - kapłan diecezji płockiej, proboszcz parafii Zielona Mławska w latach 19821984.

16 Ks. Jan Maroński - kapłan diecezji płockiej, proboszcz parafii w Nowym Mieście w latach 19822007.
} 
cowników służby bezpieczeństwa. Ich efekty są różne. W większości jednak księża ci po rozmowach, przynajmniej w wystąpieniach publicznych nie podejmują tematów politycznych.

Jak już wspomniano sprawy te były podejmowane również na spotkaniu Wojewody z bpem B[ogdanem] Sikorskim.

\section{c/ sytuacja w kościołach i związkach wyznaniowych nierzymskokatolic- kich}

Kościoły i związki wyznaniowe nierzymskokatolickie w województwie są stosunkowo nieliczne: jedna parafia ewangelicko-augsburska, dwie Katolickie Mariawitów, jedna Starokatolicka Mariawitów oraz 2 stacje kaznodziejskie Kościoła Adwentystów Dnia 7-mego i Kościoła Wolnych Chrześcijan w PRL. Z nielicznymi duchownymi tych kościołów i związków wyznaniowych stosunki układają się poprawnie. Należy dodać, iż na terenie województwa działa również Sekta Świadków Jehowy. W ostatnim okresie nastąpiła znaczna ich aktywizacja, zwłaszcza w Ciechanowie, Płońsku, w rejonie Iłowa i Żuromina.

\section{d/ polityczna aktywność stowarzyszeń świeckich}

W województwie działają następujące stowarzyszenia wyznaniowe:

1. Stowarzyszenie „Pax”, które oprócz oddziału wojewódzkiego, posiada 4 oddziały miejskie /Działdowo, Mława, Pułtusk, Żuromin/ i ostatnio zorganizowane koło środowiskowe w Płońsku. Skupia w swoich szeregach 173 członków i 198 kandydatów. W stosunku do poprzedniego okresu sprawozdawczego nastąpił nieznaczny spadek ilości członków /o 2-ch/, ale jednocześnie dosyć znaczny wzrost kandydatów - o 59 osób.

Żywszą działalność stowarzyszenia notowano tylko w okresie przygotowań i przebiegu wizyty papieża w Polsce. Organizowane w tym czasie zebrania i odczyty poświęcone były głównie popularyzacji osoby papieża i znaczeniu pielgrzymki do kraju ojczystego. Poza tym działalność skupiła się przede wszystkim na sprawach wewnątrzorganizacyjnych, zwłaszcza zaś na pozyskiwaniu nowych sympatyków.

Przewodniczący Oddz[iału] Woj[ewódzkiego] ${ }^{17}$ zabiega szczególnie o rozwój stowarzyszenia, licząc na uznanie i odpowiednią ocenę ze strony swoich władz zwierzchnich. Ponadto jest on członkiem Społecznej Rady Konsultacyjno-Doradczej przy Wojewodzie Ciechanowskim oraz z[astęp]cą Przewodniczącego Wojewódzkiej Rady PRON.

2. Chrześcijańskie Stowarzyszenie Społeczne Oddz[iał] Woj[ewódzki] z siedzibą w Płońsku, liczące 20 członków zwyczajnych i 355 członków uczestników /tych ostatnich wzrost w porównaniu do roku 1982 - o 42 osoby/.

Podobnie jak „Pax” ożywioną działalność oddz[iał] prowadził podczas pielgrzymki papieża. Szczególnie przewodniczący Oddziału ${ }^{18}$ angażował się aktyw-

\footnotetext{
Przewodniczącym Oddziału Wojewódzkiego „Pax” w Ciechanowie w tym okresie był Tadeusz Chądzyński.

18 Przewodniczącym Oddziału Wojewódzkiego ChSS z siedzibą w Płońsku w tym okresie był Franciszek Benendo.
} 
nie w organizowanie pielgrzymek do Rzymu z okazji Roku Odkupienia. Jest on aktywnym członkiem Rady Wojewódzkiej PRON.

3. Polski Związek Katolicko-Społeczny Oddz[iał] Woj[ewódzki] również z siedzibą w Płońsku, liczy zaledwie 8 członków i 33 sympatyków. Praktycznie nie przejawia żadnej działalności.

\section{B. Inicjatywy władz politycznych i administracyjnych w zakresie polityki wyznaniowej i ich efektywność}

W okresie sprawozdawczym sprawy wyznaniowe były przedmiotem posiedzenia na Zespole Wojewódzkim d/s Kleru tylko raz, przed wizytą papieża. Dokonano wówczas oceny aktualnej sytuacji i związanych z tym zarysowujących się tendencji. Zapoznając się z zaleceniami i wytycznymi władz centralnych w tym zakresie, ustalono jednocześnie kierunkowe wytyczne działań politycznych i administracyjnych.

Przejawy szkodliwej działalności kleru były również podejmowane w pierwszym półroczu ub[iegłego] r[oku] na posiedzeniach WKO.

\section{Funkcjonowanie Wydziału w 1983 r.}

a. cele jakie stawiał przed sobą Wydział w roku 1983

Głównym celem wydziału w minionym roku była dalsza praca nad lojalizacją duchowieństwa rzymskokatolickiego, a szczególnie poprzez osobiste kontakty i rozmowy z księżmi, wykorzystując do tego każdą nadarzającą się okazję.

Kolejnym istotnym zadaniem wydziału było dalsze umacnianie przestrzegania prawa w dziedzinie wyznaniowej. Przyjęto jako zasadę reagowania w każdym przypadku naruszania obowiązujących przepisów prawa, przede wszystkim poprzez rozmowy profilaktyczno-ostrzegawcze.

\section{b/ ważniejsze poczynania Wydziału w sferze administrowania stosunkami wyznaniowymi}

W tej dziedzinie w szczególności: umacniano koordynacyjną rolę Wydziału w sprawach budownictwa sakralnego i kościelnego, zwłaszcza dot[yczącego] obiektów do $600 \mathrm{~m}^{2}$ powierzchni.

Kontynuowana jest praktyka konsultowania z Wydziałem wszystkich ważniejszych spraw dot[yczących] kościołów i związków wyznaniowych merytorycznie załatwianych przez inne wydziały U[rzędu] W[ojewódzkiego], jednostki podporządkowane Wojewodzie i podstawowe jednostki administracji państwowej / rolne, cmentarnictwa wyznaniowego, nadzoru budowlanego, konserwatorskiego, podatkowego, zgromadzeń, punktów katechetycznych itp./. Zależnie od potrzeb organizowano spotkania z zainteresowanymi dyrektorami wydziałów lub kierownikami innych jednostek celem ustalania kierunków postępowania w określonych sprawach lub dziedzinach, jak również uzgadniania konkretnych decyzji.

Nadal kontynuowana jest praktyka okresowych spotkań z naczelnikami jednostek podstawowych, a szczególnie z nowopowołanymi na te stanowiska i udzielania im na miejscu pomocy oraz niezbędnego instruktażu w rozwiązywaniu kon- 
kretnych spraw wyznaniowych, zwłaszcza zaś odpowiedniego przygotowania ich do spotkań i kontaktów osobistych z księżmi.

\section{c/ przejawy i efekty współpracy z innymi ogniwami aparatu państwowego}

Najbardziej efektywnie układa się współpraca z Wydziałem IV SB. Częste kontakty, wymiana informacji, a szczególnie bieżąca, pogłębiona informacja dostarczana przez SB przyczynia się do lepszego rozeznania sytuacji i nastrojów wśród kleru, a zarazem ustalania niezbędnych przedsięwzięć i trafniejszego podejmowania decyzji.

Ponadto do efektów współpracy z innymi ogniwami aparatu państwowego należy zaliczyć:

- konsultowanie przez Wojewódzkiego Konserwatora Zabytków wszystkich spraw dot[yczących] remontów, konserwacji i dofinansowania obiektów sakralnych i kościelnych o charakterze zabytkowym;

- sukcesywną konsultację i uzgadnianie postępowania w polityce fiskalnej;

- bieżącą koordynację i konsultację spraw związanych z inwestycjami sakralnymi i kościelnymi oraz budowy lub rozbudowy cmentarzy wyznaniowych;

- uzgadnianie postępowania w sprawach nadzoru i kontroli nad stowarzyszeniami wyznaniowymi, wydawania zezwoleń na organizowanie zgromadzeń /pielgrzymki, procesje, święcenia pól itp./.

\section{d/ warunki organizacyjne i materialne działalności Wydziału}

Wydział posiada 3 osobową obsadę etatową/dyrektor i dwóch pracowników - starszy inspektor wojewódzki i inspektor wojewódzki/ ${ }^{19}$. Etaty wszystkie obsadzone.

Dyrektor i st[arszy] inspektor woj[ewódzki] z wykształceniem wyższym, insp[ektor] woj[ewódzki] - średnie. Dwie osoby ze stażem pracy ponad 20-letnim, w wydziale od powstania województwa/1.06.1975 r./, st[arszy] insp[ektor] woj[ewódzki] ze stażem 16 lat, w wydziale od 1.07.1983 r.

Pod względem kwalifikacji zawodowych i kryteriów ideowo-politycznych oraz zaangażowania społeczno-politycznego pracownicy odpowiadają wymaganiom.

W oddanym do użytku w 1983 r. gmachu U[rzędu] W[ojewódzkiego] - wydział posiada 3 pomieszczenia biurowe, wyposażony jest w niezbędny sprzęt i urządzenia /szafy metalowe, maszyny do pisania w tym jedna elektryczna/ oraz materiały kancelaryjne, zapewniające w zasadzie normalne jego funkcjonowanie.

\section{e/ postulaty pod adresem władz centralnych}

1. Wydaje się, że należałoby wreszcie wypracować konkretne ramy perspektywicznej polityki wyznaniowej z jasno sprecyzowanymi celami, uwzględniającą realia, ale pryncypalną. Dotychczasowa, w odczuciu nie tylko profesjonalistów, ma wiele cech improwizacji /”jak trwoga to do Boga”/.

9 Pracownikami Wydziału ds. Wyznań Urzędu Wojewódzkiego w Ciechanowie w tym okresie byli: dyrektor - mgr Władysław Milanowski (zatrudniony w wydziale od 1 czerwca 1975 r.), starszy inspektor wojewódzki mgr Krystyn Płoski (zatrudniony w wydziale od 1 lipca 1983 r.) oraz inspektor wojewódzki Wanda Ciećko (zatrudniona w wydziale od 1 czerwca 1975 r.). 
2. Pryncypia polityki wyznaniowej należałoby szerzej podejmować w poważnej publicystyce, zwłaszcza w prasie. Również rzeczową, mądrą polemikę. Parafrazując - „chowaniem głowy w piasek niczego nie osiągniemy”.

3. Naszym zdaniem należałoby poddać reasumpcji Zarządzenie Nr 47 Prezesa Rady Ministrów z dnia 24 listopada 1981 r. W zasadzie każdy wniosek do wojewody lub Naczelnika w sprawie zgody na budowę obiektu sakralnego lub kościelnego musi być załatwiony pozytywnie. Z praktyki wiadomo, iż próby perswazji i odwoływania się do dobrej woli przedstawicieli kościoła rzymskokatolickiego, nawet $w$ ewidentnie uzasadnionych przypadkach nic nie dają. Dlatego też czy nie wrócić do tego Zarządzenia i jego ustaleń, a przynajmniej zmiany § 10 dot[yczącego] obiektów do $600 \mathrm{~m}^{2}$ powierzchni, w którym powinien znaleźć się zapis określający termin składania wniosków, np. pod koniec roku na rok następny.

4. Unormowania wymaga sytuacja prawna Sekty Świadków Jehowy. Notuje się znaczną aktywizację niektórych środowisk. Występują z wnioskami o zezwolenia na zgromadzenia, a nawet były przypadki składania podań o zwolnienie z obowiązku rejestracji - wynikającego z ustawy z dnia 26 października $1982 \mathrm{r}$. w sprawie postępowania wobec uchylających się od pracy/Dz.U. [1982] Nr 35 poz. 229/ - ponieważ są kaznodziejami.

5. Warto rozważyć - czy nie należałoby w ogóle uporządkować w jednolitym akcie prawnym sprawy kościołów i związków wyznaniowych.

6. Naszym zdaniem należałoby zlikwidować „instytucję” rekompensat dla katechetów.

7. Systematycznie należałoby organizować okresowe kursy lub narady instruktażowo-szkoleniowe dla pracowników wydziałów z wybranych zagadnień problematyki wyznaniowej.

8. Wydaje się, iż wymaga rozważenia - czy „Problemy Wyznań i Laicyzacji” powinny wyręczać wydawnictwa kościelne w apologetyce dostojników, zwłaszcza Kościoła Rzymskokatolickiego. Tak to przecież doskonale robią ostatnio m.in. prasa paxowska.

Ciechanów, dnia 27 stycznia $1984 \mathrm{r}^{\mathrm{c}}$

Wykonano w 4 egz.

Egz. Nr 1 - Urząd do Spraw Wyznań w Warszawie

Egz. Nr 2 - K[omitet] W[ojewódzki] PZPR w Ciechanowie

Egz. Nr 3-4-a/a

$\mathrm{WM} / \mathrm{WC}^{\mathrm{d}}$

Źródło: AAN, Urzq̨d d/s Wyznań w Warszawie, sygn. 128/53, k. 35-45, oryginał, mps.

\footnotetext{
c Po prawej stronie podłużna pieczq̨tka: Dyrektor Wydziału d/s Wyznań mgr Władysław Milanowski i odręczny podpis.

d Adnotacja o osobach sporzq̨dzających pismo: W[ładysław] M[ilanowski] i W[anda] C[iećko].
} 


\section{Nr 8}

1985 czerwiec 4, Ciechanów - Sprawozdanie z wizytacji Wydziału do Spraw Wyznań Urzędu Wojewódzkiego w Ciechanowie

\section{Sprawozdanie}

z wizytacji Wydziału do Spraw Wyznań Urzędu Wojewódzkiego w Ciechanowie przeprowadzonej w dniu 4 czerwca 1985 r. przez radcę prawnego Mariana Imbierskiego i radcę Krzysztofa Poźniaka.

W toku wizytacji przeprowadzono rozmowy z dyrektorem Wydziału Władysławem Milanowskim ${ }^{1}$ oraz jego pracownikami, jak również zapoznano się z dokumentacją.

Z uwagi na fakt, iż w dniach 3 i 4 czerwca odbywało się sympozjum naukowe poświęcone historii walk o utrwalenie władzy ludowej /w Poświętnem/ i jednym z głównych organizatorów sympozjum był WUSW nie przeprowadzono rozmów z naczelnikiem Wydziału IV WUSW ani też z kierownictwem Wydziału Społeczno-Administracyjnego KW PZPR.

Wojewoda Ciechanowski tow. Jerzy Wierzchowski², mimo iż był uprzedzony o wizytacji Wydziału nie mógł nas przyjąć z uwagi na fakt, iż obowiązki służbowe zmusiły go do wyjazdu do Warszawy.

\section{Dane ogólne o województwie}

Województwo Ciechanowskie obejmuje obszar 6,4 tys. km² tj. 2 \% ogólnej powierzchni kraju. W skład województwa wchodzi 48 jednostek podziału administracyjnego tj. 2 miasta, 7 miast i gmin, 39 gmin.

Ludność województwa liczy ok. 413 tys. mieszkańców, z tego ok. 134 tys. stanowią mieszkańcy miast tj. 32,4 \% ogółu ludności województwa.

Województwo ma przede wszystkim charakter rolniczy. 89,3 \% użytków rolnych znajduje się w posiadaniu rolników indywidualnych.

Większymi zakładami przemysłowymi na terenie województwa są:

Z. P. O. W. Hortex w Płońsku

Z. P. C. im. 22 Lipca w Płońsku

Zakład Narzędzi „VIS” w Ciechanowie

Zakłady Dźwigów w Mławie

Filia Zakładów „Instal” w Nasielsku

Zakłady Produkcyjne Materiałów Budowlanych w Gralewie

Dwie cukrownie w Ciechanowie i Glinojecku.

Jednakże wymienione zakłady produkcyjne w niskim stopniu rzutują na strukturę zawodową ludności na terenie województwa.

Władysław Milanowski - dyrektor Wydziału ds. Wyznań Urzędu Wojewódzkiego w Ciechanowie w latach 1975-1988.

2 Jerzy Adam Wierzchowski - wojewoda ciechanowski w latach 1975-1987. 
Wybór dokumentów Wydziału do Spraw Wyznań Urzędu Wojewódzkiego w Ciechanowie...

\section{Dane dotyczące Kościoła Rzymskokatolickiego}

Na terenie województwa działają parafie wchodzące w skład diecezji płockiej, chełmińskiej i warmińskiej.

I tak z diecezji płockiej - 100 parafii

z diecezji chełmińskiej - 14 parafii

z diecezji warmińskiej - 1 parafia

Łącznie - 115 parafii

Od roku 1975 przybyło 11 parafii, z tym że faktycznie nowych są 4 parafie, pozostałe były to wikariaty eksponowane, które zostały przemianowane na parafie.

Proboszczy [!] na terenie województwa jest 114 - dwie parafie obsługiwane są przez jednego proboszcza.

Na terenie województwa, którego część wchodzi w skład diecezji płockiej znajduje się 9 dekanatów, diecezji chełmińskiej 2 dekanaty.

Struktura wiekowa proboszczy [!]

\begin{tabular}{|c|c|c|c|c|}
\hline \multicolumn{5}{|c|}{ Urodzeni w latach } \\
\hline & $1900-20$ & $1921-30$ & $1931-40$ & $1941-50$ \\
\hline diecezja płocka & 11 & 17 & 52 & 19 \\
\hline diecezja chełmińska & 1 & 4 & 5 & 4 \\
\hline diecezja warmińska & & & 1 & \\
\hline
\end{tabular}

Pochodzenie społeczne proboszczy [!]

Inteligenckie Robotnicze Rzemieśl[nicze] Chłopskie diecezja płocka 6

12

3

78

diecezja chełmińska

1

3

3

7

diecezja warmińska

Porównanie liczby dziekanów i proboszczy [!] w latach 1979, 80, 84 Liczba dziekanów

\begin{tabular}{|c|c|c|c|}
\hline & 1979 & 1980 & 1984 \\
\hline diecezja płocka & 8 & 8 & 10 \\
\hline diecezja chełmińska & 1 & 1 & 2 \\
\hline
\end{tabular}




\begin{tabular}{|c|c|c|c|}
\hline \multirow{3}{*}{ diecezja płocka } & \multicolumn{3}{|c|}{ Liczba proboszczy [!] } \\
\hline & 1979 & 1980 & 1984 \\
\hline & 85 & 86 & 89 \\
\hline diecezja chełmińska & 13 & 13 & 12 \\
\hline diecezja warmińska & 1 & 1 & 1 \\
\hline
\end{tabular}

Wszyscy proboszczowie złożyli i podpisali ślubowania.

Na terenie województwa nie ma parafii zakonnych, jak również nie ma domów zakonnych męskich.

Natomiast na terenie województwa zlokalizowanych jest 16 domów zakonnych żeńskich. Są to w większości niewielkie domy zakonne. Przebywające w nich zakonnice uprawiają działki przyzagrodowe, obsługują kościoły, pracują jako katechetki oraz częściowo w służbie zdrowia. Łącznie w tych domach zakonnych przebywa aktualnie 85 zakonnic, w większości są to osoby w wieku starszym. W stosunku do roku 1975 nastąpił spadek liczby domów zakonnych i zakonnic, albowiem w roku 1975 były 23 domy zakonne i 135 zakonnic.

Największy dom zakonny znajduje się w miejscowości Ratowo gm. Radzanów. Jest to dom Zgromadzenia Sióstr Misjonarek Świętej Rodziny - habitowe. Aktualnie przebywa tam 28 zakonnic, w wieku starszym i głównym ich zajęciem jest uprawa działki stanowiącej własność domu zakonnego. Pomimo faktu, iż jest to największy dom zakonny na terenie województwa to nie rzutuje on w żaden sposób na okolicznych mieszkańców.

Kontakty Wydziału z poszczególnymi domami zakonnymi są sporadyczne i w zasadzie ograniczają się do załatwiania konkretnych spraw związanych z remontem domu lub rozbudową.

Aktualnie na terenie województwa budowanych jest 5 kościołów o powierzchni ponad $600 \mathrm{~m}^{2}$. Kościoły te budowane są w miejscowościach: Płońsk, Ciechanów, Glinojeck, Strzegowo. Ponadto budowany jest kościół w miejscowości Siemiątkowo o powierzchni poniżej $600 \mathrm{~m}^{2}$. Należy przy tym zaznaczyć, iż w miejscowościach Ciechanów, Strzegowo, Rybno nie są jeszcze prowadzone prace budowlane; został dopiero zakończony etap dokumentacyjny. Oprócz budowy kościołów aktualnie budowane są jeszcze 3 kaplice, w miejscowościach: Pietrzyk, Łukowo, Hartowiec.

W ostatnim okresie czasu nie notowano przypadków budów nielegalnych.

Obecnie nie są budowane punkty katechetyczne, jak również nie wpłynął żaden wniosek do Wydziału dotyczący budowy punktu katechetycznego.

W roku 1978 na terenie województwa było 326 punktów katechetycznych, w których prowadzono naukę religii, z tego 6 punktów dotyczyło wyznań nierzymskokatolickich. W roku tym z 24 osobami była podpisana umowa o organizowanie i prowadzenie nauki religii. 
W roku 1980 było tylko 278 punktów katechetycznych /łącznie z innymi wyznaniami/, przy czym z tą samą liczbą osób były podpisane umowy.

Na koniec roku 1984 było łącznie 284 punkty nauczania religii, przy czym w obiektach kościelnych bądź sakralnych mieściło się 127 punktów, a w 157 przypadkach wynajmowano lokale od osób fizycznych. Ilość podpisanych umów o organizowanie i prowadzenie zajęć nauki religii pozostaje na tym samym poziomie.

Odnośnie wystąpień księży zawierających treści polityczne, to daje się zauważyć fakt, iż przede wszystkim młodzi wikariusze w kazaniach zawierają ujemne oceny polityczne obecnej rzeczywistości.

Ks. Tadeusz Łebkowski ${ }^{3}$ - były kapelan „Solidarności” płockiej, obecnie przebywający w Mławie w parafii św. Rodziny [!], oprócz kazań o treści politycznej, w wystroju ${ }^{a}$ kościoła zawarł fragmenty kazań ks. Jerzego Popiełuszki.

Wikariusz ks. Andrzej Zembrzuski z Żuromina ${ }^{5}$, który ma powierzoną funkcję diecezjalnego moderatora „ruchu oazowego”, przy urządzaniu szopki oraz grobu zawarł akcenty polityczne.

Ks. [Wiesław] Kosek ${ }^{6}$ - na terenie Nasielska próbuje organizować duszpasterstwo rolników indywidualnych. Zdaniem dyrektora Wydziału jak na razie nie ma on szerszego poparcia wśród miejscowych rolników.

Odwrotna sytuacja ma miejsce w miejscowości Lutocin. Byłe aktywne środowisko b[yłej] „Solidarności Rolników Indywidualnych” wywarło nacisk na miejscowego proboszcza ${ }^{7}$ celem zorganizowania duszpasterstwa rolników. Zdaniem dyrektora Wydziału proboszcz zgodził się na to, albowiem chce ująć ten oddolny ruch w „karby”. Odbyły się dwa spotkania, jednakże na obu nie odnotowano akcentów politycznych. Proboszcz obiecuje spotkania z fachowcami z poszczególnych dziedzin rolnictwa. W ten sposób chce opanować oddolny ruch i przekazać miejscowym nowoczesną wiedzę rolniczą.

Znacznie łagodniejsze wystąpienia księży o charakterze politycznym odnotowano także w Płońsku /wikariusz [ks. Marek] Smogorzewski ${ }^{8}$ - parafia p. w. św. Maksymiliana Kolbe/ oraz w miejscowości Glinojeck - proboszcz [ks. Franciszek] Gall ${ }^{9} /$ jednakże w ostatnim okresie czasu zaprzestał wygłaszania kazań o treści politycznej/.

W każdym wypadku wystąpień o charakterze politycznym były przeprowadzane rozmowy z proboszczami. Skutkiem rozmów było albo okresowe wyci-

$3 \quad$ Ks. Tadeusz Łebkowski - kapłan diecezji płockiej, wikariusz parafii św. Stanisława BM w Mławie w latach 1982-1986, wcześniej wikariusz parafii św. Jana Chrzciciela w Płocku i kapelan „Solidarności”.

4 Błędnie podano wezwanie parafii mławskiej. Ksiądz Łebkowski był wikariuszem parafii św. Stanisława BM w Mławie.

a Błędnie wpisano: wastroju.

$5 \quad$ Ks. Andrzej Zembrzuski - kapłan diecezji płockiej, wikariusz parafii w Żurominie w latach 1982-1986.

${ }_{6} \quad$ Ks. Wiesław Kosek - kapłan diecezji płockiej, wikariusz parafii w Nasielsku w latach 1980-1985.

7 Chodzi o ks. Sławomira Aleksandra Malinowskiego, proboszcza parafii Lutocin w latach 1981-1988.

8 Ks. Marek Smogorzewski - kapłan diecezji płockiej, wikariusz parafii św. Maksymiliana Kolbego w Płońsku w latach 1984-1985.

9 Ks. Franciszek Gal - kapłan diecezji płockiej, proboszcz parafii Glinojeck w latach 1980-1998. 
szenie księży, albo zaprzestanie wygłaszania tego typu kazań /proboszcz Gall/. W przeszłości biskup [Bogdan] Sikorski ${ }^{10}$ obiecał Wojewodzie Ciechanowskiemu rozwiązanie tego problemu. Od momentu przybycia do Płocka biskupa [Zygmunta] Kamińskiego ${ }^{11}$ tematu tego jeszcze nie podjęto.

Na terenie województwa poza przypadkiem Żuromina /ks. Zembrzuski, o którym wyżej wspomniano/ nie notuje się zorganizowanych form „ruchu oazowego”. Można nawet stwierdzić, iż poza tym jednym przypadkiem nie notuje się większego zainteresowania ruchem ani wśród księży ani wśród mieszkańców.

Na terenie województwa nie były organizowane obozy „oazowe”. Tym niemniej były przypadki wyjazdów dzieci na obozy organizowane na terenie Podkarpacia. Dzieci te pochodziły z terenu Żuromina i Nasielska.

Problem krzyży w szkołach jest pozostałością z lat 1980-1981. Były sporadyczne próby w latach 1983-1984 zawieszania nowych krzyży, ale bezskuteczne. Próby te były w rejonach miast Ciechanów, Mława, Nasielsk i Żuromin. Nie było takiego przypadku na terenach administrowanych przez Kurię Chełmińską. Ilość krzyży w stosunku do roku 1982 zmalała o około 50 \% i aktualnie znajdują się w czterdziestu kilku obiektach.

W wyborach do rad narodowych ogółem brało udział 53,5\% księży. Z ogólnej liczby proboszczy [!] głosowało 72.6\%, wikariuszy 24\%, księży emerytów $50 \%$. W rozbiciu na poszczególne diecezje problem ten przedstawia się następująco:

Ogółem proboszczowie wikariusze emeryci

\begin{tabular}{|c|c|c|c|c|}
\hline diecezja płocka & $52,3 \%$ & $69,4 \%$ & $27,4 \%$ & $43 \%$ \\
\hline diecezja chełmińska & $60 \%$ & $93 \%$ & $0 \%$ & $100 \%$ \\
\hline diecezja warmińska & $100 \%$ & $100 \%$ & -- & -- \\
\hline
\end{tabular}

Należy zaznaczyć, iż z diecezji warmińskiej na terenie województwa jest tylko jeden proboszcz. Z diecezji chełmińskiej wielu wikariuszy na terenach plebani zameldowanych jest tylko na pobyt czasowy. Nie zwrócono uwagi na możliwość zgłoszenia ich do głosowania w miejscu pobytu i tym m.in. należy tłumaczyć fakt, iż nie brali oni ${ }^{\mathrm{b}}$ udziału w głosowaniu.

10 Biskup Bogdan Marian Sikorski - duchowny pochodzący z archidiecezji poznańskiej, w latach 1964-1988 biskup płocki, od 1984 r. przekazał - z polecenia Stolicy Apostolskiej - władzę biskupowi Zygmuntowi Kamińskiemu, administratorowi apostolskiemu „sede plena”, zachowując jedynie tytuł ordynariusza płockiego.

11 Biskup Zygmunt Kamiński - duchowny pochodzący z diecezji lubelskiej, biskup pomocniczy lubelski (1975-1984), biskup koadiutor diecezji płockiej „sede plena” (1984-1988), biskup płocki (1988-1999), arcybiskup metropolita szczecińsko-kamieński (1999-2009), od 2009 r. arcybiskup senior szczecińsko-kamieński. 
Przed wyborami nie było przypadków, aby z ambony księża wprost wzywali do bojkotu wyborów, a były natomiast przypadki pozytywne, iż przypominali o tym obywatelskim obowiązku.

Do „Caritasu” aktualnie należy 12 księży w wieku starszym. Nie mają oni oddzielnego lokalu i ich status aktualnie nie jest do końca unormowany. Księża należeli formalnie do Oddziału Warszawskiego. W latach 1982-1983 były propozycje, aby członkowie „Caritasu” należeli formalnie do Oddziału w Płocku. Do chwili wizytacji formalnie nie została ta sprawa unormowana. Zdaniem dyrektora Wydziału nie ma szans na rozwój organizacji na ternie województwa.

\section{Stowarzyszenia wyznaniowe}

[Stowarzyszenie] PAX - aktualnie liczy 191 członków i 234 sympatyków. Oddziałów na terenie województwa jest 6. Lokal dla biura jest wynajmowany. W planie miasta jest budowa pawilonu, w którym na dole byłyby sklepy i punkty usługowe, a na górze przewiduje się lokal na potrzeby PAX-u. Prezes oddziału wojewódzkiego ${ }^{12}$ wchodzi w skład kolegium doradczego Wojewody. Spośród członków PAX-u jest dwóch radnych Wojewódzkiej Rady Narodowej, mają również swoich przedstawicieli w radach miejskich. Przedstawiciel PAX-u jest wiceprzewodniczącym Rady Wojewódzkiej PRON. Zdaniem władz wojewódzkich osłabła działalność PAX-u, albowiem najwyższa ich działalność była w latach 1980-1981.

CHSS [Chrześcijańskie Stowarzyszenie Społeczne] - oddział wojewódzki z siedzibą w Płońsku. Liczy 20 członków i 378 sympatyków. Honorowy przewodniczący oddziału ${ }^{13}$ jest działaczem PRON-u. Lokal biurowy wynajmowany jest w budynku stanowiącym własność przewodniczącego. Działalność Stowarzyszenia jest mało widoczna na terenie województwa.

PZKS [Polski Związek Katolicko-Społeczny] - oddział wojewódzki z siedzibą w Płońsku. Liczy 8 członków i 33 sympatyków. Bardzo mało widoczni na terenie województwa.

\section{Nierzymskokatolickie kościoły i związki wyznaniowe na terenie województwa.}

Na terenie województwa ciechanowskiego działa 5 kościołów nierzymskokatolickich. Jednakże tylko dwa z nich tj. Kościół Ewangelicko-Augsburski i Kościół Starokatolicki Mariawitów w PRL zrzeszają większą ilość wiernych. Praktycznie jednak żaden z tych kościołów nie odgrywa znaczącej roli.

1. Kościół Ewangelicko-Augsburski liczy około 360 wyznawców. Na terenie województwa znajduje się jedna parafia w Działdowie, która obsługiwana jest przez proboszcza z Ostródy.

\footnotetext{
Zapisano: ono.

12 Przewodniczącym Oddziału Wojewódzkiego „Pax” w Ciechanowie w tym okresie był Tadeusz Chądzyński.

13 Honorowym przewodniczącym Oddziału Wojewódzkiego ChSS z siedzibą w Płońsku w tym okresie był dr Franciszek Benendo.
} 
2. Kościół Starokatolicki Mariawitów w PRL liczy około 370 wyznawców. Na terenie województwa znajduje się jedna parafia w miejscowości Radzyminek gm. Naruszewo. W tej parafii proboszczem był biskup [Zdzisław Maria Włodzimierz] Jaworski ${ }^{14}$.

3. Kościół Katolicki Mariawitów w PRL - liczy około 130 wyznawców. Na terenie województwa dwie parafie obsługiwane przez zakonnice.

4. Kościół Adwentystów Dnia Siódmego - liczy czterech wyznawców. Na terenie województwa jedna stacja w miejscowości Dębsk.

5. Kościół Wolnych Chrześcijan - brak bliższych danych odnośnie liczny ich wyznawców, w każdym bądź razie zdaniem dyrektora Wydziału ich liczba nie przekracza kilkudziesięciu. Na terenie województwa znajdują się trzy stacje: Kosewo gm. Nasielsk, Iłowo, Mława.

Odnośnie liczby wyznawców św. [!] Jehowy Wydział posiada ogólne rozpoznanie oceniając na około 500 osób. Można jedynie stwierdzić, iż zlokalizowani są na terenie miast i okolic Ciechanowa, Płońska i Iłowa. Na terenie województwa rozpoczęli dopiero swą działalność aktywną. Były wnioski o odbycie zgromadzeń.

\section{Sytuacja Wydziału}

Wydział zlokalizowany jest na drugim piętrze nowo wzniesionego pawilonu, w którym mieści się Urząd Wojewódzki. Warunki pracy bardzo dobre.

Pracownicy Wydziału pracują w jednym pokoju, ale w każdej chwili mogą, celem odbycia rozmowy z interesantem - jeśli nie ma odpowiednich warunków w pokoju - przejść do przedpokoju, który znajduje się między ich pokojem a gabinetem dyrektora. W pomieszczeniu tym znajduje się stolik i krzesła i stanowi on zarazem poczekalnię dla interesantów.

W Wydziale jest etat dyrektora i dwóch pracowników. Wszystkie etaty są obsadzone.

Dyrektor Wydziału mgr Władysław Milanowski ${ }^{15}$ kieruje wydziałem od 1 czerwca 1975 r. Wcześniej do końca marca 1950 r. pracował w organach MO, w administracji państwowej, a od 1 listopada 1955 r. do 1 czerwca 1975 r. w aparacie partyjnym. Członek Zakładowej Komisji Kontroli Partyjnej, sekretarz Zarządu Wojewódzkiego ZBoWiD, wiceprezes Klubu Oficerów Rezerwy, członek Wojewódzkiego Społecznego Komitetu ORMO, członek TPPR. Wykształcenie wyższe. Zarobki [...]; łącznie [...]. Dobrze ocenia współpracę z Wydziałem IV WUSW i z KW PZPR. Uważa, iż Wojewoda Ciechanowski tow. Jerzy Wierzchowski przejawia duże zainteresowanie problematyką wyznaniową. Pracę podległych jemu pracowników ocenia pozytywnie.

14 Ks. Zdzisław Maria Włodzimierz Jaworski - polski biskup mariawicki, w latach 1961-1983 proboszcz parafii św. Piotra i Pawła Apostołów w Radzyminku.

15 Zob. przyp. 1. 
Krystyn Płoski ${ }^{16}$ - st[arszy] inspektor wojewódzki. Wykształcenie wyższe, od dwóch lat w Wydziale; natomiast w Urzędzie Wojewódzkim pracuje od roku 1980. Łączny staż pracy 18 lat. Członek PZPR. Społecznie prowadzi wykłady w TWP, lektor TKKŚ, wiceprzewodniczący koła TPPR przy Urzędzie Wojewódzkim. W Wydziale zajmuje się sprawami budownictwa, sytuacją prawną nieruchomości wyznaniowych, finansami, stowarzyszeniami, planowaniem pracy oraz kościołami i związkami nierzymskokatolickimi. Płaca zasadnicza [...]; zarobki łącznie [...]. Dyrektora Wydziału ocenia jako wymagającego, drobiazgowego, który czuje się związany z Urzędem. Natomiast dyrektor ocenia go jako pracownika nieźle przygotowanego, posiadającego już nieco doświadczenia, bystrego, przejawiającego dużo inicjatywy i samodzielności. Ocenę z okresowego przeglądu uzyskał więcej niż dobrą.

Wanda Ciećko ${ }^{17}$ - inspektor wojewódzki, wykształcenie średnie, w Wydziale od 10 lat. Zajmuje się sprawami organizacyjnymi Wydziału, prowadzeniem teczek parafii, sprawami zakonów żeńskich, prowadzi listy płacy za nauczanie religii. Członek PZPR, wchodzi w skład egzekutywy POP, wiceprzewodnicząca koła TPPR przy Urzędzie Wojewódzkim, członek Rady Pracowniczej. Zarobki łączne [...], z czego płaca zasadnicza [...]. Uważa, że ich zarobki w stosunku do pracowników innych wydziałów Urzędu Wojewódzkiego są niskie. Posiada Srebrny Krzyż Zasługi oraz Medal XL-lecia. Wysoko ocenia dyrektora Wydziału za jego doświadczenie i znajomość zagadnień.

Dokumentacja Wydziału przechowywana jest w szafach metalowych w przedpokoju między pokojem pracowników a gabinetem dyrektora.

Teczki poszczególnych parafii, zakonów, innych wyznań i stowarzyszeń są opisane na grzbietach i oznaczone numerem. Nie ma problemu z odnalezieniem potrzebnej teczki. Korespondencja prowadzona jest rzeczowo i terminowo. Warunki lokalowe oraz techniczne bardzo dobre.

Nie prowadzi się oddzielnych szkoleń dla naczelników gmin i miast, lecz przy okazji szkoleń z innych tematów dyrektor wydziału ma zarezerwowany czas, aby przekazać informacje z zakresu polityki wyznaniowej.

Jak już zaznaczono na wstępie sprawozdania, z uwagi na odbywające się sympozjum naukowe na temat walk o utrwalenie władzy ludowej na Ziemi Ciechanowskiej nie przeprowadzono rozmów z przedstawicielami Wydziału IV WUSW oraz z KW PZPR.

\section{Marian Imbierski ${ }^{c}$ \\ Krzysztof Poźniak ${ }^{\mathrm{d}}$.}

Źródło: AAN, Urzq̨d d/s Wyznań w Warszawie, sygn. 128/53, k. 20-29, oryginał, mps.

16 Krystyn Płoski - pracownik Wydziału ds. Wyznań Urzędu Wojewódzkiego w Ciechanowie w latach 1983-1989.

17 Wanda Ciećko - pracownik Wydziału ds. Wyznań Urzędu Wojewódzkiego w Ciechanowie w latach 1975-1989.

c Powyżej odręczny podpis.

d Powyżej odręczny podpis. 


\section{$\operatorname{Nr} 9$}

1985 czerwiec 5, Płock - Sprawozdanie z wizytacji Wydziału do Spraw Wyznań Urzędu Wojewódzkiego w Płocku

\section{Sprawozdanie}

z wizytacji Wydziału do Spraw Wyznań Urzędu Wojewódzkiego

w Płocku przeprowadzonej w dniu 5 czerwca 1985 r. przez

p.o. dyrektora Biura Prawnego Bogusława Skretę, radcę prawnego Mariana Imbierskiego i radcę Krzysztofa Poźniaka.

W toku wizytacji przeprowadzono rozmowy z kierownikiem Wydziału Społeczno-Prawnego KW PZPR tow. Adamem Różańskim ${ }^{1}$, naczelnikiem Wydziału IV WUSW tow. Jerzym Pisarski², p.o. dyrektora Wydziału do Spraw Wyznań tow. Kazimierzem Wielcem ${ }^{3}$ oraz pracownicą Wydziału Barbarą Płachecką ${ }^{4}$.

Kierownik zespołu wizytacyjnego odbył krótką rozmowę z Wojewodą Płockim tow. Antonim Bielakiem ${ }^{5}$.

Nadto wizytujący poznali przyszłego dyrektora Wydziału do Spraw Wyznań tow. dr Tadeusza Willanda [!] ${ }^{6} /$ bliższe dane w dalszej części opracowania/.

\section{Dane ogólne o województwie}

Województwo płockie obejmuje obszar $3.117 \mathrm{~km}^{2}$, a więc jest województwem o średniej wielkości w kraju pod względem obszarowym. Liczy nieco ponad 500 tys. mieszkańców. Ludność w połowie utrzymuje się z rolnictwa, a w połowie z pracy w przemyśle.

Administracyjnie województwo podzielone jest na 50 jednostek podstawowych tj. 6 miast, 3 miasta i gminy i 41 gmin. Miasta to Płock, Kutno, Gostynin, Łęczyca, Sierpc, Żychlin. Należy zaznaczyć, iż województwo płockie zostało utworzone z obszaru dawnych województw warszawskiego, łódzkiego i bydgoskiego.

Do największych zakładów przemysłowych na terenie województwa należą:

- Mazowieckie Zakłady Rafineryjne i Petrochemiczne w Płocku zatrudniające ok. 8,5 tys. pracowników

- Fabryka Maszyn Żniwnych w Płocku - zatrudniająca ok. 3,5 tys. pracowników

Adam Różański - działacz PZPR, od 1972 r. kierownik Wydziału Organizacyjnego Komitetu Miejskiego i Powiatowego PZPR, a następnie KW PZPR w Płocku.

2 Płk. Jerzy Pisarski - funkcjonariusz SB, w latach 1982-1989 naczelnik Wydziału IV KWMO w Płocku.

$3 \quad$ Kazimierz Wielec - dyrektor Wydziału ds. Wyznań Urzędu Wojewódzkiego w Płocku w latach 1975-1984, w latach 1984-1985 p.o. dyrektora.

4 Barbara Płachecka - pracownik Wydziału ds. Wyznań Urzędu Wojewódzkiego w Płocku w latach 1979-1989.

Antoni Bielak - wojewoda płocki w latach 1980-1990.

$6 \quad$ Tadeusz Wiland - dyrektor Wydziału ds. Wyznań Urzędu Wojewódzkiego w Płocku w latach 1985-1987. 
- Przedsiębiorstwo Budownictwa „Petrobudowa” w Płocku, przedsiębiorstwo to budowało kombinat petrochemiczny, lecz w chwili obecnej buduje poza terenem województwa jak i poza granicami kraju

- Zakład „Polam” w Gostyninie - zatrudniające ok. 2,5 tys. pracowników

- Zakłady Podzespołów Radiowych „Miflex” w Kutnie - zatrudniające ok. 1,5 tys. pracowników

- Stocznia Rzeczna w Płocku

- Zakłady „Polfa” w Kutnie

- Fabryka Maszyn Żniwnych „Kraj” w Kutnie

- Centrala Części Zamiennych „Agroma” w Kutnie /o pełnej automatyzacji/

- Zakłady Transformatorów i Silników Elektrycznych „Emit” w Żychlinie.

Województwo płockie jest województwem o nastawieniu przemysłowo-rolniczym. Pod względem realizacji produkcji rolniczej zajmuje siódme miejsce w kraju, natomiast pod względem warunków glebowych zajmuje siedemnaste miejsce. Jest województwem o najmniejszej powierzchni lasów, albowiem zajmują one tylko 11\% powierzchni województwa.

\section{Dane dotyczące Kościoła Rzymskokatolickiego}

Na terenie województwa działają parafie wchodzące w skład diecezji płockiej, warszawskiej, łódzkiej i włocławskiej.

I tak z diecezji płockiej - 87 parafii

$z$ diecezji warszawskiej - 28 parafii

z diecezji łódzkiej - 12 parafii

z diecezji włocławskiej - 2 parafie

Łącznie - 129 parafii

Dekanatów z terenu diecezji płockiej 8, diecezji warszawskiej 3 i diecezji łódzkiej 2.

Wszystkie parafie obsadzone przez proboszczy [!], a jedynie w trzech przypadkach mianowanie proboszczy [!] nastąpiło wbrew postanowieniom dekretu z 1956 r. o organizowaniu i obsadzaniu stanowisk kościelnych. Kurie informują o zamiarze mianowania księdza proboszczem danej parafii.

Kuria warszawska najpierw mianuje danego księdza administratorem parafii i o tym fakcie zawsze informuje Wydział; natomiast nie zawsze informuje w terminie o fakcie mianowania tegoż administratora parafii proboszczem.

Z pominięciem wyżej wymienionych trzech proboszczy [!], pozostali złożyli i podpisali ślubowania. Były przypadki, iż proboszczowie odmawiali napisania życiorysu lub też wypełnienia kwestionariusza. Przypadki takie były sporadyczne, a w związku z tym, iż złożyli i podpisali ślubowania, to nie robiono z tego problemu.

Odnośnie wystąpień publicznych księży, w których to wystąpieniach zawarte 
były elementy polityczne, to należy wskazać przede wszystkim na następujących księży i parafie:

- Parafia Głogowiec, proboszcz ks. Marian Lipski ${ }^{7}$ /obsadzony niezgodnie z dekretem/. W ostatnim okresie czasu w kazaniach poruszał nawet kwestie przedłużenia mocy obowiązującej Układu Warszawskiego. W stosunku do jego osoby rozważana jest możliwość wszczęcia postępowania administracyjnego;

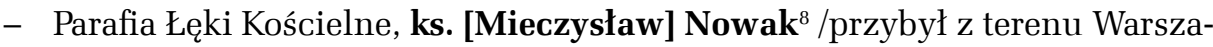
wy-Ursusa/. W dniu 2 czerwca br. odbyło się nabożeństwo w intencji Ojca Świętego Jana Pawła II, z udziałem delegacji z kilkunastu województw. Najliczniej reprezentowana była Łódź, ze [Andrzejem] Słowikiem ${ }^{9}$ na czele. Impreza ta organizowana była przez ks. Nowaka. Zachodziła obawa, że zostanie zorganizowana głodówka;

- Parafia św. Stanisława [Kostki] w Płocku, jest to parafia zakonna XX Salezjanów. Kazania o treści politycznej wygłasza nie proboszcz lecz zaproszeni goście;

- Parafia św. Jadwigi w Płocku, gdzie również kazania wygłaszają zapraszani goście. Proboszcz parafii ks. [Mieczysław] Zdanowski ${ }^{10}$ tłumaczy się iż nie ma wpływu na treść kazań przez nich wygłaszanych.

Jeśli chodzi o księży Lipskiego i Nowaka to nie mają oni posłuchu wśród miejscowych księży, ale i ogół księży nie ma wpływu na nich. Są wyizolowani w swoim miejscowym środowisku, ale jednocześnie bardzo samodzielni.

Na terenie województwa nie ma aktualnie nielegalnych budów; była budowa jednej kaplicy, ale została zalegalizowana.

Aktualnie w budowie jest sześć obiektów sakralnych; w tym jedna kaplica oraz pięć kościołów o powierzchni ponad $600 \mathrm{~m}^{2}$.

Odnośnie problemu krzyży w szkołach to aktualnie są zawieszone w 13 szkołach. Są to pozostałości z lat 1980-1981. Były w latach 1983-1984 próby zawieszania nowych krzyży w szkołach, ale ostatecznie nie doszło do ich zawieszenia.

Większość punktów katechetycznych mieści się w obiektach sakralnych i kościelnych, lecz około 1/4 punktów mieści się w lokalach wynajmowanych od osób fizycznych. Wydział nie posiada informacji w jakiej wysokości kształtuje się odpłata za wynajmowany lokal. Nie ma przypadku, aby punkt katechetyczny mieścił się w pomieszczeniach szkolnych. Od roku 1975 wpłynęło do Wydziału 8 wniosków o budowę nowych pomieszczeń katechetycznych. Aktualnie z 23 osobami

Ks. Marian Lipski - kapłan archidiecezji warszawskiej, proboszcz parafii św. Wojciecha w Głogowcu w latach 1982-1998, kapelan podziemnej „Solidarności”.

8 Ks. Mieczysław Nowak - kapłan archidiecezji warszawskiej, proboszcz parafii Łęki Kościelne w latach 1984-1992, wcześniej wikariusz parafii św. Józefa Oblubieńca NMP w Warszawie-Ursusie.

9 Andrzej Eugeniusz Słowik - działacz związkowy i opozycjonista, jeden z przywódców „Solidarności” Ziemi Łódzkiej.

10 Ks. Mieczysław Zdanowski - kapłan diecezji płockiej, w latach 1981-1986 proboszcz parafii bł. Jadwigi Królowej w Płocku. 
podpisane są umowy o organizowanie i prowadzenie punktów katechetycznych, z czego 9 osób dotyczy religii nierzymskokatolickich.

W początkach lat 80-tych były organizowane obozy letnie „ruchu oazowego” w miejscowości Gorzewo nad jeziorem Białym. Obecnie nie ma zorganizowanych form obozowych, tym niemniej były przypadki wyjazdów indywidualnych dzieci na obozy letnie na teren Podkarpacia.

Należy jednak zaznaczyć, iż w ostatnich miesiącach daje się odczuć silny nacisk Kościoła na organizowanie akcji letniej dla dzieci i młodzieży. Akcja ta ma być prowadzona szczególnie na terenie diecezji płockiej, gdzie wspiera ją bardzo intensywnie biskup Z[ygmunt] Kamiński ${ }^{11}$. Do celów akcji letniej ma być wykorzystywana również sieć punktów katechetycznych. Nacisk kładzie się również na to, aby dzieci uczestniczące w akcji letniej, organizowanej przez instytucje państwowe miały możliwość zbiorowego udziału co najmniej w nabożeństwach niedzielnych.

Na terenie województwa na uwagę zasługuje przede wszystkim to co dzieje się w diecezji płockiej. Jest obecnie prowadzona zupełnie inna polityka, niż za rządów biskupa [Bogdana] Sikorskiego ${ }^{12}$. Biskup Sikorski był w swoim działaniu bardzo statyczny. Pewną aktywność wykazywał tylko w zakresie budownictwa sakralnego. Biskup Kamiński jest natomiast bardzo aktywny, wyraźnie postawił na młodych księży i młodzież. Według jego wizji Kościół/diecezja płocka/ma być czystya, dynamiczny, ma energicznie pozyskiwać młode pokolenie, a przede wszystkim inteligencję, tak aby za 10-15 lat Kościół nie miał większych problemów.

Usuwani są ze stanowisk proboszczów księża zbyt zasiedziali, starsi, a na ich miejsce biskup Kamiński wprowadza księży młodych, nie powiązanych „sprawami przyziemnymi”/dzieci, układy towarzyskie/ z miejscowym środowiskiem.

Postawę b[isku]p[a] Kamińskiego w jakiś sposób obrazują również pewne posunięcia związane z wizytą [arcybiskupa] L[uigi] Poggiego ${ }^{13}$. 8 czerwca ma odbyć się jego spotkanie z młodzieżą w Mławie. Jest to nagroda dla ks. [Tadeusza] Łebkowskiego $^{14}$ - b[yłego] kapelana „Solidarności” w Płocku - za jego pracę z młodzieżą. Ks. Łebkowski i jemu podobni będą najprawdopodobniej w najbliższym okresie czasu awansowani do ważniejszych ośrodków miejskich i do Kurii, celem

${ }_{11}$ Biskup Zygmunt Kamiński - duchowny pochodzący z diecezji lubelskiej, biskup pomocniczy lubelski (1975-1984), biskup koadiutor diecezji płockiej „sede plena” (1984-1988), biskup płocki (1988-1999), arcybiskup metropolita szczecińsko-kamieński (1999-2009), od 2009 r. arcybiskup senior szczecińsko-kamieński.

12 Biskup Bogdan Marian Sikorski - duchowny pochodzący z archidiecezji poznańskiej, w latach 1964-1988 biskup płocki, od 1984 r. przekazał - z polecenia Stolicy Apostolskiej - władzę biskupowi Zygmuntowi Kamińskiemu, administratorowi apostolskiemu „sede plena”, zachowując jedynie tytuł ordynariusza płockiego.

a Powinno być chyba: czynny.

13 Kardynał Luigi Poggi - dyplomata watykański, od 1975 r. przedstawiciel Stolicy Apostolskiej do stałych kontaktów roboczych z Polską. Jako arcybiskup i wysłannik Jana Pawła II w dniach 5-8 czerwca 1985 r. przebywał w diecezji płockiej.

14 Ks. Tadeusz Łebkowski - kapłan diecezji płockiej, wikariusz parafii św. Stanisława BM w Mławie w latach 1982-1986, wcześniej wikariusz parafii św. Jana Chrzciciela w Płocku i kapelan „Solidarności”. 
organizowania pracy z młodzieżą. W związku z tym trzeba poświęcić dużo uwagi organizacjom młodzieżowym, a nade wszystko należy odpowiednio ukierunkować działalność władz oświatowych.

IV Piesza Pielgrzymka Płocka do Częstochowy ma liczyć według aktualnych przewidywań ok. 12 tys. uczestników, z czego zdecydowana większość ok. 80-90\% to młodzież szkolna. Kierownikiem duchowym pielgrzymki jest już tradycyjnie ks. Marek Smogorzewski ${ }^{15}$. Dużą rolę odgrywa również w tym przedsięwzięciu ks. Łebkowski.

Na ternie województwa działa 10 zakonów żeńskich i 4 męskie. Do większych zakonów żeńskich działających na terenie województwa należy zaliczyć Zgromadzenie Męki Serca Pana Jezusa i Zgromadzenie Służek Niepokalanej Maryi Panny, które mają po 9 domów zakonnych.

Zakonnice w większości zajmują się uprawą roli, hodowlą, nauką religii, obsługą kościołów oraz pracą w domach pomocy społecznej. Niepokojącym faktem jest to, iż zakonnice działające dotychczas w domach pomocy społecznej przestawiane są na działalność w punktach katechetycznych.

Natomiast z zakonów męskich należy wskazać na XX Salezjanów, którzy w Czerwińsku posiadają nowicjat, a w Woźniakowie k/Kutna - studentat.

Oddział wojewódzki „Caritasu” w chwili obecnej liczy 16 członków. Wszyscy są w wieku starszym, ze wyjątkiem prezesa oddziału Wacława Macieji. Wszyscy księża ukrywają przed Kurią fakt przynależności do „Caritasu”. Zdaniem władz wojewódzkich nie mają szans rozwinięcia swoich szeregów i działalności. Posiadają lokal biurowy w pobliżu Urzędu Wojewódzkiego.

\section{Stowarzyszenia wyznaniowe}

Stowarzyszenia wyznaniowe nie odgrywają większej roli w województwie. I tak ChSS [Chrześcijańskie Stowarzyszenie Społeczne] nie posiada swojego oddziału, pomimo iż były próby jego utworzenia.

[Stowarzyszenie] PAX - oddział wojewódzki liczący 51 członków. 4 oddziały

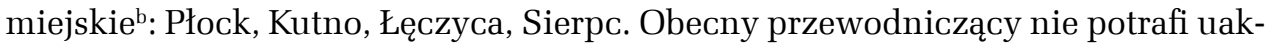
tywnić członków stowarzyszenia.

PZKS [Polski Związek Katolicko-Społeczny] - oddział wojewódzki liczący ok.

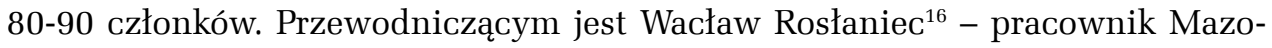
wieckich Zakładów Rafineryjnych i Petrochemicznych. Obecnie Wydział nie ma z oddziałem kontaktu.

15 Ks. Marek Smogorzewski - kapłan diecezji płockiej, wikariusz parafii św. Bartłomieja w Płocku (1979-1980), parafii Świętej Trójcy w Rypinie (1981-1984), parafii św. Maksymiliana Kolbego w Płońsku (1984-1985), duszpasterz młodzieży i współorganizator Pieszej Pielgrzymki Płockiej na Jasną Górę.

b Zapisano błędnie: miejski.

16 Wacław Rosłaniec - inżynier geodeta, od 1960 r. zatrudniony w płockiej Petrochemii, a następnie w Wojewódzkim Biurze Geodezji i Terenów Rolniczych w Płocku. W 1980 r. delegat diecezji płockiej na synod biskupów w Rzymie poświęcony sprawom rodziny, od 1980 r. prezes Polskiego Związku Katolicko-Społecznego w Płocku. 
W momencie wprowadzenia stanu wojennego na terenie województwa nie było KIK-u. Obecnie jest grupa założycielska, którą opiekuje się osobiście biskup Kamiński. Grupa ta złożyła już stosowne dokumenty, celem zarejestrowania stowarzyszenia. Trzeba liczyć się realnie z tym, że KIK w Płocku powstanie. W ocenie władz miejscowych brak jest podstaw do wydania w tej sprawie negatywnej decyzji. W grupie założycielskiej nie ma osób, które można by zaliczyć do miejscowej ekstremy politycznej. Jednym z głównych inicjatorów całego przedsięwzięcia jest były przewodniczący oddziału wojewódzkiego „Pax”, członek WRN poprzedniej kadencji pan [Eugeniusz] Aleksandrowicz ${ }^{17}$. Obecnie jest on skłócony z „Paxem”.

\section{Kościoły i wyznania nierzymskokatolickie}

Na terenie województwa działa siedem kościołów i związków wyznaniowych nierzymskokatolickich:

1. Kościół Ewangelicko-Augsburski - posiada parafie w Kutnie, Łęczycy, Płocku, Gostyninie. Nie jest kościołem liczącym się na terenie województwa. Wydział nie posiada bliższych danych odnośnie liczby wyznawców.

2. Polski Autokefaliczny Kościół Prawosławny - zdaniem pracownika Wydziału jest to kościół, który na terenie województwa jest już na wymarciu.

3. Starokatolicki Kościół Mariawitów w PRL - bp [Stanisława Maria Tymoteusz] Kowalski ${ }^{18}$, liczy ok. 200 wyznawców na terenie województwa jest 5 parafii. Wiek wyznawców jest zróżnicowany.

4. Kościół Mariawitów w PRL - Wydział nie posiada aktualnych danych o liczbie i strukturze wiekowej wyznawców.

5. Świecki Ruch Misyjny „Epifania” - wyznawców kilku /ok. 5/, na czele związku na terenie województwa ob. Bogdan Nowicki ${ }^{19}$.

6. Adwentyści Dnia Siódmego - liczą aktualnie 6 wyznawców.

7. Stowarzyszenie Badaczy Pisma Św. - aktualnie liczy około kilkunastu wyznawców. Przewodniczący Zboru zamieszkuje na terenie Płocka.

\section{Sytuacja Wydziału}

Wydział mieści się w starym budynku, w którym zlokalizowany jest Urząd Wojewódzki. Zajmuje dwa pokoje. W Wydziale są dwa etaty plus etat dyrektora. W chwili wizytacji prawidłowo obsadzony był tylko jeden etat. Od lata ubiegłego roku /lipiec/ dyrektor Wydziału do Spraw Wyznań tow. Kazimierz Wielec formalnie odszedł z Wydziału; został dyrektorem Wydziału Organizacyjnego. Tym niemniej [wykonuje] nadal powierzone mu obowiązki dyrektora Wydziału do Spraw Wyznań. Z tego tytułu nie otrzymuje dodatkowego wynagrodzenia. Sytuacja taka w znacznym stopniu

17 Eugeniusz Michał Aleksandrowicz - przewodniczący Zarządu Wojewódzkiego Stowarzyszenia „Pax” w Płocku w latach 1979-1982, następnie jeden z członków założycieli Klubu Inteligencji Katolickiej w Płocku.

18 Biskup Stanisław Maria Tymoteusz Kowalski - od 1972 r. zwierzchnik Starokatolickiego Kościoła Mariawitów w PRL.

19 Bogdan Nowicki - zwierzchnik Ruchu Misyjnego „Epifania” w województwie płockim. 
rzutuje na pracę Wydziału. Zatrudniona w charakterze starszego inspektora wojewódzkiego Barbara Płachecka będąc praktycznie samą w Wydziale załatwia przede wszystkim sprawy bieżące. Tym samym nie jest możliwa prawidłowa praca z przedstawicielami kościołów i związków wyznaniowych. Nie dokonuje się również pracy analitycznej nad zachodzącymi zmianami w kościołach.

Barbara Płachecka ${ }^{20}$ - starszy inspektor wojewódzki, w Wydziale od 1979 r. Poprzednio pracowała w szkole podstawowej, w PBP „Orbis”. Od lipca 1984 r. praktycznie sama w Wydziale. Bezpartyjna, bez odznaczeń. Aktualnie studentka pierwszego roku Studium Administracyjnego Wydziału Prawa i Administracji Uniwersytetu Warszawskiego /studia magisterskie po ukończeniu ZSA/. Ustalony ma już temat pracy magisterskiej z zakresu administracji wyznaniowej. Zarobki [...]; łącznie [...]. Odpowiada jej praca w Wydziale, tym niemniej uważa, iż w innych wydziałach Urzędu Wojewódzkiego pracownicy o podobnym stażu pracy posiadają wyższe zarobki. Bardzo dobrze ocenia współpracę z dyrektorem Wielcem. Uważa go za przełożonego wymagającego, konkretnego, posiadającego dużą znajomość zagadnień, a jednocześnie pozostawiającego pracownikowi dużą swobodę w pracy. W toku wizytacji zgłosiła wniosek, aby pracownicy Wydziałów mieli możliwość zapoznania się z metodami pracy Wydziałów w innych województwach. Uważa, iż w tym celu winni być oddelegowani na kilka dni do innych województw. Wydaje się, iż wniosek ten można rozważyć, albo w formie zaproponowanej przez koleżankę Płachecką, albo też w toku szkoleń na kursie przekazywać obecnym te metody i sposoby pracy z województw, w których najlepiej pracują Wydziały do Spraw Wyznań.

Wizytującym został przedstawiony przyszły dyrektor Wydziału tow. dr Tadeusz Willand [!] ${ }^{21}$. Tow. Willand [!] wyraził już zgodę na objęcie stanowiska. I Sekretarz KW PZPR i Wojewoda Płocki ustalili, iż tow. Willand [!] obejmie obowiązki dyrektora Wydziału od 1 września 1985 r. Studia doktoranckie tow. Willand [!] ukończył w Szkole Nauk Społecznych przy KC PZPR. Po nostryfikacji dyplomu jest doktorem nauk humanistycznych. Obecnie jest kierownikiem Wojewódzkiego Ośrodka Kształcenia Ideologicznego KW PZPR w Płocku. Studia magisterskie ukończył na Wydziale Filologii Rosyjskiej Uniwersytetu Warszawskiego. W Komitecie Wojewódzkim PZPR w Płocku pracuje od 10 lat. Wcześniej pracował jako nauczyciel języka rosyjskiego w szkolnictwie, a następnie jako wizytator - metodyk w Wydziale Oświaty, Wychowania i Kultury w Gostyninie.

Dokumentacja Wydziału przechowywana jest w szafach pancernych. Teczki poszczególnych parafii, zgromadzeń zakonnych oraz kościołów nierzymskokatolickich opisane są na grzbietach. Dokumentacja dotycząca kościoła rzymskokatolickiego ustawiona w układzie alfabetycznym. Nie ma problemu z odnalezieniem wymaganej teczki. Korespondencja prowadzona jest rzeczowo i w większości przypadków terminowo.

20 Zob. przyp. 4.

21 Zob. przyp. 6. 
Jak już zaznaczono w niniejszym sprawozdaniu nadal nie jest obsadzony etat drugiego pracownika Wydziału i na dzień wizytacji nie było kandydata. Skutkiem czego - jak już zaznaczono - koleżanka Płachecka załatwia przede wszystkim sprawy bieżące. Nie dokonuje żadnej analizy zmian w poszczególnych kościołach i związkach wyznaniowych, nie ma również pracy z przedstawicielami zakonów.

Kontakty z naczelnikami miast i gmin są w toku odpraw kwartalnych. Zawsze w toku tych odpraw jest rezerwowany czas dla przedstawiciela Wydziału, który przekazuje wytyczne bądź ustalenia. Nowi naczelnicy prezentowani są w zasadzie w toku tych odpraw. Wojewoda przypomina naczelnikom, iż sprawy wyznaniowe należy zgłaszać bezpośrednio do Wydziału. Naczelnikom pozostawiono prawo dysponowania talonami na dodatkową benzynę, z tym, że dany ksiądz musi zgłosić się z podaniem zaopiniowanym przez dyrektora Wydziału.

Reasumując należy stwierdzić, iż po objęciu stanowiska przez nowego dyrektora Wydziału sprawą pilną będzie obsadzenie wakatu, co umożliwi dopiero spokojną metodyczną pracę.

\section{Bogusław Skręta ${ }^{\mathrm{c}} \quad$ Marian Imbierski $^{\mathrm{d}} \quad$ Krzysztof Poźniak $^{\mathrm{e}}$}

Źródło: AAN, Urzqd d/s Wyznań w Warszawie, sygn. 128/80, k. 6-15, oryginat, mps.

\section{Nr 10}

1986 styczeń 15, Ciechanów - Plan pracy Wydziału d/s Wyznań Urzędu Wojewódzkiego w Ciechanowie na rok 1986

Zatwierdzam

Ciechanów, $1986-01-15^{\mathrm{a}}$

Wojewoda Ciechanowski

Poufne

Jerzy Wierzchowski ${ }^{\mathrm{b}}$

Egz. Nr 1

Wz. Pf-10/86

\section{Plan pracy}

Wydziału do Spraw Wyznań Urzędu Wojewódzkiego

w Ciechanowie na 1986 rok $^{\mathrm{c}}$

\footnotetext{
Powyżej odręczny podpis.

Powyżej odręczny podpis.

Powyżej odręczny podpis.

Data dzienna wpisana ręcznie.

Odręczny podpis na zatwierdzeniu.

Poniżej tekst wpisany w tabelę o następujących rubrykach: Lp/Zadania/Termin realizacji/Odpowiedzialny za realizację/Uwagi do wykonania.
} 


\section{Zadania:}

1. Realizacja dekretu z 31. XII. 1956 r. o organizowaniu i obsadzaniu stanowisk kościelnych

a/ rozpatrywanie wniosków kurii biskupich dot[yczących] erygowania nowych i zmiany granic istniejących parafii

b/ rozpatrywanie wniosków kurii biskupich dot[yczących] mianowania księży na stanowiska proboszczów parafii

c/ opracowanie informacji o przebiegu realizacji dekretu na terenie woj[ewództwa] ciechanowskiego w $1986 \mathrm{r}$.

Termin realizacji: cały okres sprawozdawczy - punkt c/ 30. XII. 86

Odpowiedzialni za realizację: Wł[adysław] Milanowski ${ }^{1}$, K[rystyn] Płoski², W[anda] Ciećko ${ }^{3}$.

2. Praca z duchowieństwem rzymskokatolickim ze szczególnym uwzględnieniem podstawowych wytycznych i założeń polityki wyznaniowej określonych w tezach i uchwałach X Zjazdu PZPR

a/ dalsza stała praca nad lojalizacją przede wszystkim duchowieństwa rzymskokatolickiego

b/ podejmowanie działań przeciwko przejawom klerykalizmu

c/ współpraca z duchowieństwem zrzeszonym i współpracującym z Caritas, Pax i ChSS.

Termin realizacji: cały okres sprawozdawczy.

Odpowiedzialni za realizację: Wł[adysław] Milanowski, K[rystyn] Płoski.

3. Nadzór nad punktami katechetycznymi:

a/ wspólnie z Kuratorium Oświaty i Wychowania dokonać oceny stanu punktów katechetycznych i opracować odpowiednie wnioski:

b/ w rozmowach i spotkaniach z duchownymi, a szczególnie kościoła rzymskokatolickiego podejmować tematykę upowszechniania wysiłków naszego państwa na rzecz pokojowego współistnienia, utrwalania terytorialnopolitycznych realiów w Europie opartych na układach jałtańskich ${ }^{\mathrm{d}}$, poczdamskich oraz krzewienia poczucia współodpowiedzialności za sprawy państwa i narodu;

c/ kontynuować pracę nad zwiększeniem ilości umów z księżmi katechetami. Termin realizacji: cały okres sprawozdawczy.

Odpowiedzialni za realizację: Wł[adysław] Milanowski, K[rystyn] Płoski, W[anda] Ciećko.

4. Budownictwo sakralne i kościelne:

Władysław Milanowski - dyrektor Wydziału d/s Wyznań Urzędu Wojewódzkiego w Ciechanowie w latach 1975-1988.

2 Krystyn Płoski - pracownik Wydziału d/s Wyznań Urzędu Wojewódzkiego w Ciechanowie w latach 1983-1989.

3 Wanda Ciećko - pracownik Wydziału d/s Wyznań Urzędu Wojewódzkiego w Ciechanowie w latach 1975-1989.

d W oryginale słowo to zapisane wielkq literq. 
a/ odbyć spotkania konsultacyjne z przedstawicielami kurii biskupich, celem dokonania uzgodnień dot[yczących] inwestycji sakralnych i kościelnych na lata 1986-1990.

b/ opracować zestawienie wybudowanych w latach 1975-1985 obiektów sakralnych i kościelnych.

c/ opracować zestawienie wszystkich zgłoszonych wniosków budowlanych przez kurie i proboszczów w latach 1975-1985.

d/ wspólnie z nadzorem budowlanym i Wojewódzkim Konserwatorem Zabytków przeprowadzić kontrolę realizacji budownictwa sakralnego i kościelnego, zwłaszcza pod kątem zgodności z dokumentacją. Kontrolą objąć wszystkie inwestycje sakralne i kościelne. Zebrane wnioski wykorzystać do okresowych ocen i informacji, a szczególnie związanych z polityką inwestycyjną w tym zakresie.

e/ w ramach współpracy z naczelnikami t[erenowych] o[rganizacji] a[dministracji] p[aństwowej] i organami MO podejmować na bieżąco niezbędne działania przeciwko nielegalnemu budownictwu sakralnemu i kościelnemu.

Termin realizacji i odpowiedzialni za realizację:

pkt. a/ do 31.01.1986 r. - Wł[adysław] Milanowski, K[rystyn] Płoski

pkt. b/ do 30.07.1986 [r.] - K[rystyn] Płoski

pkt. c/ do 30.08.1986 [r.] - K[rystyn] Płoski

pkt. d/ do 1.12.1986 [r.] - K[rystyn] Płoski

pkt. e/ cały okres sprawozdawczy - Wł[adysław] Milanowski, K[rystyn] Płoski

5. Polityka fiskalna:

a/ wspólnie z Izbą Skarbową dokonać realizacji podatków w 1985 r.

b/ wspólnie z Wydziałem Finansowym U[rzędu] W[ojewódzkiego] dokonać oceny realizacji podatku rolnego za $1985 \mathrm{r}$.

c/ wspólnie z Izbą Skarbową i Wydziałem Finansowym przeprowadzać systematyczne kontrole przebiegu realizacji podatków w 1986 r. Kontrolami tym objąć cały teren województwa.

Termin realizacji i odpowiedzialni za realizację:

pkt. a/ do 30.05.1986 [r.] - Wł[adysław] Milanowski, K]rystyn] Płoski

pkt. b/ do 30.05.1986 [r.] - Wł[adysław] Milanowski, K[rsytyn] Płoski

pkt. c/ cały okres sprawozdawczy - K[rystyn] Płoski

6. Realizacja ustawy z 20.03.1950 $\mathrm{r}^{4}$

Przeprowadzenie postępowania w sprawach:

a/ wydawania decyzji o gospodarstwie rolnym proboszcza

b/ zbywanie, nabywanie, zamiana gruntów i innych nieruchomości przez jednostki kościelne i związki wyznaniowe.

Termin realizacji: cały okres sprawozdawczy.

4 Chodzi o ustawę o przejęciu przez Państwo dóbr martwej ręki, poręczaniu proboszczom posiadania gospodarstw rolnych i utworzeniu Funduszu Kościelnego z 20 marca 1950 r. (Dz.U. 1950 nr 9 poz. 87). 
Odpowiedzialni za realizację: Wł[adysław] Milanowski, K[rystyn] Płoski.

7. Nadzór nad działalnością stowarzyszeń wyznaniowych /Caritas, Pax, ChSS, PZKS/.

a/ kontrola realizacji działalności statutowej

b/ opracowanie informacji o rozwoju i działalności stowarzyszeń wyznaniowych w $1986 \mathrm{r}$.

Termin realizacji: cały okres sprawozdawczy w/g odrębnego planu rocznego wspólnie z Wydz[iałem] Społ[eczno-]Adm[inistracyjnym].

Odpowiedzialni za realizację:

pkt. a/ Wł[adysław] Milanowski, K[rystyn] Płoski

pkt. b/ K[rystyn] Płoski (do 30.12.1986 r.).

8. Nadzór nad zgromadzeniami:

a/ podczas kontroli w t[erenowych] o[rganach] a[dministracji] p[aństwowej] zwrócić uwagę na prawidłowość wydawanych decyzji na zgromadzenia i zbiórki publiczne

b/ zebrane w tej sprawie spostrzeżenia i wnioski przedstawić do rozpatrzenia i ogólnego uregulowania przez Wydział Społ[eczno-]Administracyjny.

Termin realizacji: cały okres sprawozdawczy.

Odpowiedzialni za realizację: K[rystyn] Płoski.

9. Nadzór nad działalnością wyznań nierzymskokatolickich. Aktualizacji ewidencji i załatwianie bieżących spraw mniejszości wyznaniowych.

Termin realizacji: cały okres sprawozdawczy.

Odpowiedzialni za realizację: K[rystyn] Płoski, W[anda] Ciećko.

10. Ustawa z 31.01.1959 r. ${ }^{5}$

Nadzór nad cmentarzami wyznaniowymi.

Współdziałanie w tym zakresie z Wydziałem Gospodarki Komunalnej i Mieszkaniowej, a szczególnie w zakresie uporządkowania i zabezpieczania cmentarzy żydowskich, podjęcie przedsięwzięć zmierzających do generalnego uporządkowania cmentarzy ewangelickich.

Termin realizacji: cały okres sprawozdawczy.

Odpowiedzialni za realizację: K[rystyn] Płoski.

11. Ustawa z 26.10.1982 $\mathrm{r}^{6}$

Wykorzystując spotkania i rozmowy z duchowieństwem oraz kierownictwem stowarzyszeń wyznaniowych, podejmować tematykę walki z alkoholizmem i innymi zjawiskami patologii społecznej.

Termin realizacji: cały okres sprawozdawczy.

Odpowiedzialni za realizację: K[rystyn] Płoski.

12. Doskonalenie systemu zarządzania życiem społeczno-gospodarczym w województwie:

Chodzi o ustawę o cmentarzach i chowaniu zmarłych z 31 grudnia 1959 r. (Dz.U. 1959 nr 11 poz. 62). Chodzi o ustawę o wychowaniu w trzeźwości i przeciwdziałaniu alkoholizmowi z 26 października 1982 r. (Dz.U. $1982 \mathrm{nr} 35$ poz. 230). 
a/ doskonalenie systemu planowania pracy.

b/ wzmocnienie nadzoru wewnętrznego nad realizacją zadań w tym również rozpatrywania i załatwiania skarg i wniosków.

c/ określenie bieżących zasad współdziałania z t[erenowymi] o[rganami] a[dministracji] p[aństwowej] stopnia wojewódzkiego i t[erenowymi] o[rganami] a[dministracji] p[aństwowej] stopnia podstawowego w sprawach do$\mathrm{t}[$ yczących] polityki wyznaniowej.

d/ wszechstronne wykorzystywanie i popularyzacja decyzji politycznych instancji partyjnych do usprawniania działalności administracji państwowej i gospodarczej służących poprawie życia społeczno-gospodarczego w województwie.

Termin realizacji: cały okres sprawozdawczy.

Odpowiedzialni za realizację:

za całość: Wł[adysław] Milanowski, K[rystyn] Płoski

pkt. 1/-3/ K[rystyn] Płoski.

13. Popularyzacja polityki wyznaniowej, poprzez bieżącą współpracę z Towarzystwem Wiedzy Powszechnej, Towarzystwem Krzewienia Kultury Świeckiej, organizacjami młodzieżowymi ZSMP i ZMW „Wici”.

Na spotkaniach i odczytach wykorzystywać postanowienia i uchwały KC PZPR w tym szczególnie w okresie akcji sprawozdawczo-wyborczej w PZPR.

Termin realizacji: cały okres sprawozdawczy.

Odpowiedzialni za realizację: K[rystyn] Płoski.

14. Pomoc i instruktaż naczelnikom jednostek podstawowych:

- Ciechanów - Joniec

- Działdowo - Karniewo

- Lidzbark Welski - Lubowidz

- Mława - Lutocin

- Nasielsk - Nowe Miasto

- Pułtusk - Płośnica

- Płońsk - Regimin

- Raciąż - Rybno

- Żuromin - Sochocin

- Baboszewo - Strzegowo

- Czernice Borowe - Wiśniewo

- Dzierzgowo - Załuski

- Gzy

- Grudusk

Na naradach z Naczelnikami podejmować tematykę dot[yczącą] polityki wyznaniowej.

Termin realizacji: cały okres sprawozdawczy w/g planów kwartalnych.

Odpowiedzialni za realizację: Wł[adysław] Milanowski, K[rystyn] Płoski.

e W tym miejscu kończy się zapis tabelaryczny. 


\section{Wykonano w 4 egz.}

Egz. Nr 1 - Urząd do Spraw Wyznań w Warszawie

Egz. Nr 2 - Wydział Administracyjny K[omitetu] W[ojewódzkiego] PZPR

Egz. Nr 3-4 - a/a

Nr DEWD - 9/86

$\mathrm{KP} / \mathrm{WC}^{\mathrm{f}}$

Źródło: AAN, Urzq̨d d/s Wyznań w Warszawie, sygn. 128/53, k. 2-5, oryginał, mps.

\section{Nr 11}

1987 styczeń, Płock - Plan pracy Wydziału d/s Wyznań Urzędu Wojewódzkiego w Płocku w pierwszym półroczu $1987 \mathrm{r}$.

\section{PLAN}

pracy Wydziału do Spraw Wyznań U[rzędu] W[ojewódzkiego] w Płocku na I półrocze 1987 r. $^{\mathrm{a}}$

\section{Okres: STYCZEŃ}

1. Treść zadania: Opracowanie sprawozdania z działalności Wydziału w 1986 r. Odpowiedzialny za wykonanie: T[adeusz] Wiland ${ }^{1}$ Termin realizacji: 20.01.87 r.

2. Treść zadania: Przygotowanie charakterystyk b[isku]pów Odpowiedzialny za wykonanie: T[adeusz] Wiland Termin realizacji: 31.01.87 r.

3. Treść zadania: Sprawozdawczość statystyczna za 1986 r.

Odpowiedzialny za wykonanie: B[arbara] Płachecka² ${ }^{2}$ S[tanisław] Szatkowski Termin realizacji: 20.01.87 r.

4. Treść zadania: Rozmowy:

a/ z klerem parafialnym

Odpowiedzialny za wykonanie: T[adeusz] Wiland

Termin realizacji: 30.01.87 r.

b/ spotkanie z Wikariuszem Generalnym Kurii ${ }^{4}$

f Adnotacja o osobach sporzqdzajacych pismo: K[rystyn] P[łoski] i W[anda] C[iećko]. Po prawej stronie pieczq̨tka podłużna: Dyrektor Wydziału d/s Wyznań mgr Władysław Milanowski z odręcznym podpisem.

a Poniżej tekst wpisany w tabelę o następujących rubrykach: Okres/Lp/Treść zadania/Odpowiedzialny za wykonanie/Termin realizacji/Uwagi.

1 Tadeusz Wiland - dyrektor Wydziału ds. Wyznań Urzędu Wojewódzkiego w Płocku w latach 1985-1987.

2 Barbara Płachecka - pracownik Wydziału ds. Wyznań Urzędu Wojewódzkiego w Płocku w latach 1979-1989.

3 Stanisław Szatkowski - pracownik Wydziału ds. Wyznań Urzędu Wojewódzkiego w Płocku w latach 1985-1987.

4 Chodzi o ks. Władysława Lisa - kapłana diecezji płockiej, wikariusza generalnego diecezji płockiej w latach 1977-1984. 
Odpowiedzialny za wykonanie: T[adeusz] Wiland Termin realizacji: $30.01 .87 \mathrm{r}$.

Okres: LUTY

5. Treść zadania: Udział w kontroli Oddziału Wojewódzkiego PAX

Odpowiedzialny za wykonanie: T[adeusz] Wiland, B[arbara] Płachecka Termin realizacji: $26.02 .87 \mathrm{r}$.

6. Treść zadania: Spotkanie z przedstawicielami Kurii Metropolitalnej Warszawskiej, Kurii Biskupiej Łódzkiej

Odpowiedzialny za wykonanie: T[adeusz] Wiland Termin realizacji: $27.02 .87 \mathrm{r}$.

7. Treść zadania: Przygotowanie wypłaty dla katechetów

Odpowiedzialny za wykonanie: B[arbara] Płachecka

Termin realizacji: $29.02 .87 \mathrm{r}$.

Okres: MARZEC

8. Treść zadania: Spotkanie z biskupami kościołów mariawickich

Odpowiedzialny za wykonanie: T[adeusz] Wiland

Termin realizacji: $10.03 .87 \mathrm{r}$.

9. Treść zadania: Rozeznanie zakresu realizacji budownictwa sakralnego

Odpowiedzialny za wykonanie: S[tanisław] Szatkowski

Termin realizacji: $30.03 .87 \mathrm{r}$.

10. Treść zadania: Opracowanie charakterystyki kierownictwa WSD

Odpowiedzialny za wykonanie: T[adeusz] Wiland

Termin realizacji: $30.03 .87 \mathrm{r}$.

11. Treść zadania: Spotkanie z kierownictwem Oddziału Wojewódzkiego PAX

Odpowiedzialny za wykonanie: T[adeusz] Wiland

Termin realizacji: 31.03.87 $\mathrm{r}$.

Okres: KWIECIEŃ

12. Treść zadania: Uściślenie ewidencji
a/ księży
b/ zakonników i zakonnic
c/ alumnów seminarium duchownego
d/ nowicjuszy w Czerwińsku
e/ „Studentatu” w Woźniakowie

Odpowiedzialny za wykonanie: B[arbara] Płachecka, S[tanisław] Szatkowski Termin realizacji: $30.04 .87 \mathrm{r}$.

13. Treść zadania: - Opracowanie charakterystyk przełożonych zgromadzeń zakonnych.

- Rozmowy prezydentów i naczelników z klerem.

Odpowiedzialny za wykonanie: B[arbara] Płachecka

Termin realizacji: $28.04 .87 \mathrm{r}$.

14. Treść zadania: Spotkanie z Wikariuszem Generalnym Kurii

Odpowiedzialny za wykonanie: T[adeusz] Wiland 
Termin realizacji: 28.04.87 $\mathrm{r}$.

Okres: MAJ

15. Treść zadania: - Kontynuacja rozmów prezydentów i naczelników z klerem.

- Rozeznanie realizacji budownictwa kościelnego

Odpowiedzialny za wykonanie: S[tanisław] Szatkowski

Termin realizacji: 29.05.87 r.

16. Treść zadania: Przygotowanie informacji dla kierownictwa polityczno-administracyjnego o nastrojach wśród kleru w związku z wizytą Papieża w Polsce Odpowiedzialny za wykonanie: T[adeusz] Wiland Termin realizacji: 28.05.87 r.

17. Treść zadania: Opracowanie charakterystyk dziekanów

Odpowiedzialny za wykonanie: T[adeusz] Wiland

Termin realizacji: 20.05.87 r.

18. Treść zadania: Przygotowanie wypłat dla katechetów

Odpowiedzialny za wykonanie: B[arbara] Płachecka

Termin realizacji: 30.05.87 r.

Okres: CZERWIEC

19. Treść zadania: Rozeznanie przygotowań kleru do wizyty Papieża

Odpowiedzialny za wykonanie: T[adeusz] Wiland

Termin realizacji: 10.06.87 r.

20. Treść zadania: Opracowanie informacji zbiorowej o stanie budownictwa sakralnego i kościelnego

Odpowiedzialny za wykonanie: S[tanisław] Szatkowski

Termin realizacji: $2.06 .87 \mathrm{r}$.

21. Treść zadania: Wstępne rozeznanie o nastrojach wśród kleru po wizycie Papieża

Odpowiedzialny za wykonanie: T[adeusz] Wiland

Termin realizacji: 30.06.87 r.

22. Treść zadania: Ocena przygotowań do akcji letniej

Odpowiedzialny za wykonanie: T[adeusz] Wiland

Termin realizacji: $29.06 .87 \mathrm{r.}^{\mathrm{b}}$

Źródło: AAN, Urzq̨d d/s Wyznań w Warszawie, sygn. 128/104, k. 313-315, oryginał, mps.

\section{BIBIOGRAFIA}

\section{Źródła archiwalne}

Archiwum Akt Nowych w Warszawie - Urząd d/s Wyznań, 125/66,127/73, 127/74, 128/10, 128/53, 128/80, 128/93, 128/104.

b W tym miejscu kończy się zapis tabelaryczny. Poniżej pieczq̨tka: Dyrektor Wydziału dr Tadeusz Willand i podpis. 
Wybór dokumentów Wydziału do Spraw Wyznań Urzędu Wojewódzkiego w Ciechanowie...

Archiwum Państwowe w Płocku - Urząd Wojewódzki w Płocku, 9, 252, 262.

Archiwum Państwowe w Warszawie, Oddział w Mławie - Urząd Wojewódzki w Ciechanowie, 2949, 2967, 2968.

\title{
Opracowania
}

Grochowski A., Polityka wyznaniowa okresu PRL w województwie ciechanowskim, „Ziemia Zawkrzeńska” 2007, nr 11.

Misztal H., Polskie prawo wyznaniowe, t. 1: Zagadnienia wstępne. Rys historyczny, Lublin 1996.

Misztal H., Mezglewski A., Zakres kompetencji, styl działania i cele Urzędu do Spraw Wyznań, [w:] A. Mezglewski, P. Stanisz, M. Ordon (red.), Prawo i polityka wyznaniowa w Polsce Ludowej. Materiały II Ogólnopolskiego Sympozjum Prawa Wyznaniowego (Kazimierz Dolny, 26-28 października 2004), Lublin 2005.

Szymański A., Działalność Wydziału do Spraw Wyznań w Płocku wobec Kościoła katolickiego w latach 1950-1989 w świetle dokumentów Archiwum Państwowego w Płocku, „Studia z Dziejów Państwa i Prawa Polskiego” 2014, nr 17.

Zygner L., Wydział do spraw Wyznań Urzędu Wojewódzkiego w Ciechanowie 19751988/1989, [w:] R. Łatka (red.), Urzqd do Spraw Wyznań. Struktury - działalność - ludzie, t. 1: Struktury wojewódzkie i wybrane aspekty działalności, Warszawa 2020.

Zygner L., Wydział do Spraw Wyznań Urzędu Wojewódzkiego w Płocku (1975-1989), [w:] Urzqd do Spraw Wyznań. Struktury - działalność - ludzie, t. 3 (w druku).

\section{Selection of Documents of the Department for Religious Affairs of the Voivode- ship Office in Ciechanów and the Provincial Office in Płock (1975-1989) from the Collection of the Archives of New Records in Warsaw}

\begin{abstract}
The activity of the Religious Affairs Departments of the Provincial Offices in Ciechanów and Płock in the years 1975-1989, formally subordinate to the provincial governors of the new provinces established in 1975, as well as the Office for Religious Affairs in Warsaw, was one of the forms of implementing the religious policy of communist authorities. Apart from these departments' numerous documents, which are currently kept in the State Archives in Warsaw, Mława Branch (team: Voivodeship Office in Ciechanów) and in the State Archives in Płock (team: Provincial Office in Płock), many documents have also been preserved and are kept at the Archives of New Records in Warsaw (team: Office for Religious Affairs). In this selection, 11 of these documents have been published, concerning conversations with clergy conducted at meetings with voivodes and employees of departments, statistical reports on the shaping of religious relations in individual provinces, reports and annual plans on the religious situation and the activities of departments as well as post-visit documents of the Departments for Religious Affairs in Ciechanów and Płock.
\end{abstract}

Keywords: Office for Religious Affairs, Department for Religious Affairs in Ciechanów, Department for Religious Affairs in Płock, religious policy, Polish People’s Republic 